\title{
Geohydrology and Conceptual Model of a Ground-Water-Flow System Near a Superfund Site in Cheshire, Connecticut
}

By Janet Radway Stone, Paul M. Barlow, and J. Jeffrey Starn

U.S. GEOLOGICAL SURVEY

Open-File Report 96-162

Prepared in cooperation with the U.S. ENVIRONMENTAL PROTECTION AGENCY, REGION I 


\title{
U.S. DEPARTMENT OF THE INTERIOR BRUCE BABBITT, Secretary
}

\author{
U.S. GEOLOGICAL SURVEY \\ Gordon P. Eaton, Director
}

For additional information write to:

\section{District Chief}

U.S. Geological Survey

450 Main Street

Room 525

Hartford, CT 06103
Copies of this report can be purchased from:

U.S. Geological Survey

Earth Science Information Center

Open-File Reports Section

Box 25286, MS 517

Denver Federal Center

Denver, CO 80225 


\section{CONTENTS}

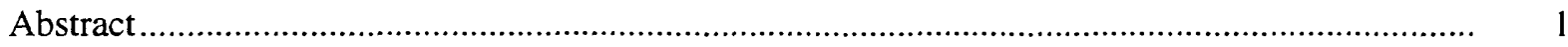

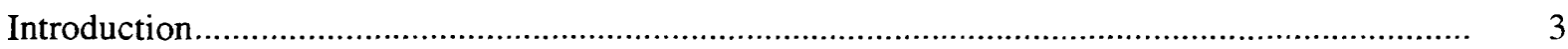

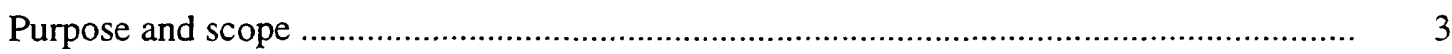

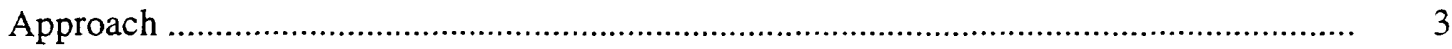

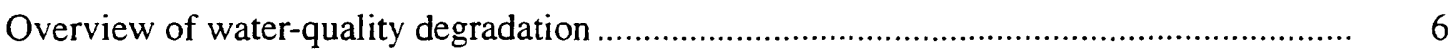

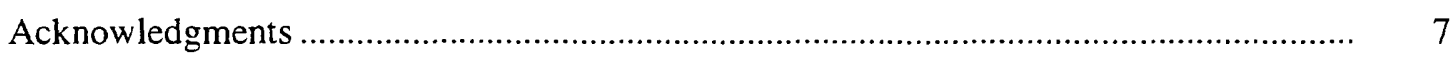

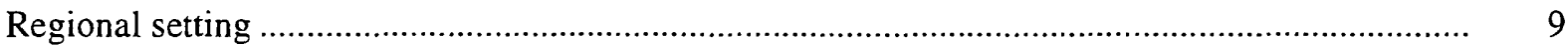

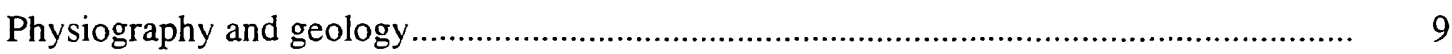

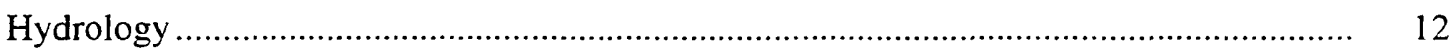

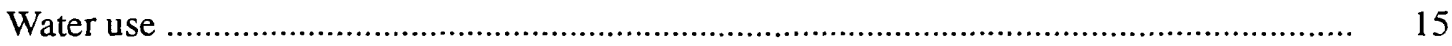

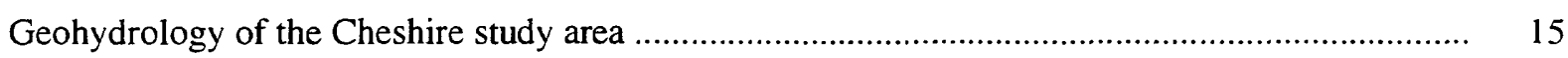

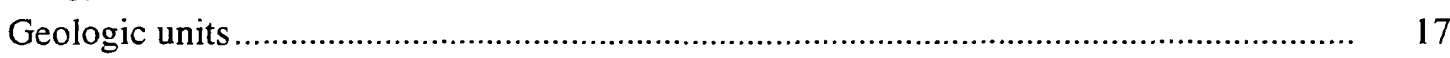

Unconsolidated materials ......................................................................... 17

Bedrock.......................................................................................... 17

Lithology ............................................................................. 17

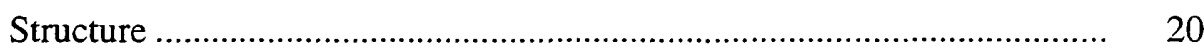

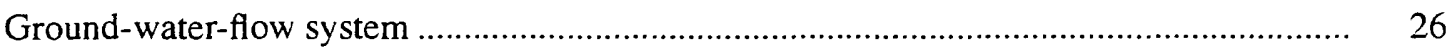

Water levels ......................................................................................... 26

Response of the fractured-bedrock aquifer to hydraulic stresses ......................... 31

Conceptual model of ground-water-flow system................................................................... 47

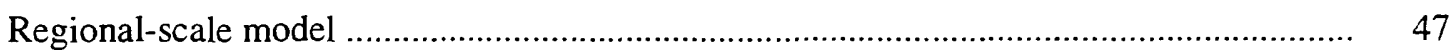

Generalized local-scale model ...................................................................... 51

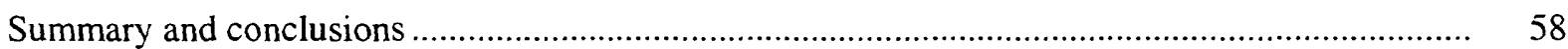

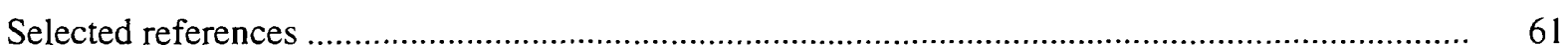

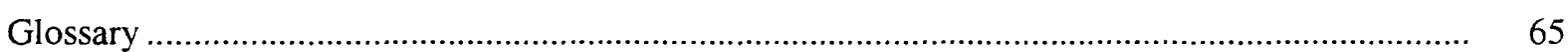

Appendix 1. Record of inventoried wells and testholes, Cheshire study area, Cheshire, Connecticut

Appendix 2. Records of borehole geophysical and core logs, Cheshire study area, Cheshire, Connecticut...

Appendix 3. Records of water-level fluctuations at selected wells, Cheshire study area, Cheshire, Connecticut......................................................................................... 77

\section{FIGURES}

1. Map showing regional area, central Connecticut ........................................................... 2

2. Map showing Cheshire study area, Cheshire, Connecticut ............................................. 4

3. Map showing regional bedrock geology, central Connecticut.......................................... 8

4. Map showing regional surficial geology, central Connecticut ..................................... 10

5. Geologic section A-A' across the Quinnipiac lowland, central Connecticut..................... 11

6. Map showing thickness of unconsolidated materials and locations of section
lines B-B' and C-C', Cheshire study area, Cheshire, Connecticut ........................... 16

7. Geologic section B-B', Cheshire study area, Cheshire, Connecticut.............................. 18

8. Geologic section C-C', Cheshire study area, Cheshire, Connecticut.............................. 19 
9. Photographs of bedrock outcrop at Rt. 691 roadcut showing eastwarddipping channel sandstone units (light color) and overbank mudstone units (dark red color)

10. Diagrams showing borehole geophysical and core logs for TH-2,

Cheshire study area, Cheshire, Connecticut

11. Rose diagrams showing strike of bedding and fractures (a and $\mathrm{c}$ ) and lower hemisphere stereo-net contoured plots of poles to bedding planes and fracture planes ( $b$ and d), Cheshire study area, Cheshire, Connecticut

12. Azimuthal plots of magnitude and direction of resistivity, Cheshire study area, Cheshire, Connecticut

13. Graph showing water-level fluctuations at CS-221 and A-2

and precipitation at nearby gaging station, Cheshire study area, Cheshire, Connecticut

14. Map showing altitude of water table, June 8, 1995, Cheshire study area, Cheshire, Connecticut

15. Graph showing drawdown of water level at CS-221 during aquifer test on December 16, 1994

16. Graphs showing water levels in CS-221, TH-2, and TH-3 during aquifer tests, June 1995

17. Graph showing water levels in selected observation wells during aquifer tests, June 1995 (A and B)

18. Graphs showing drawdown of water level at $\mathrm{TH}-2$, and $\mathrm{TH}-3$ during aquifer tests of June 15 (A) and June 16, 1995 (B)

19. Graphs showing drawdown of water level at CS-221, TH-2, and TH-3 during aquifer tests of June 15 (A) and June 16, 1995 (B)

20. Caliper log and single-well heat-pulse flowmeter log at well CS-221, Cheshire, Connecticut

21. Caliper log and single-well heat-pulse flowmeter log at well TH-1, Cheshire, Connecticut

22. Caliper log and single-well and multi-well heat-pulse flowmeter logs at well TH-2, Cheshire, Connecticut

23. Caliper log and single-well and multi-well heat-pulse flowmeter logs at well TH-3, Cheshire, Connecticut

24. Schematic section showing ground-water flow during pumping of CS-221, Cheshire, Connecticut

25. Map showing model grid and boundary conditions for the regional model at the Cheshire study area, Cheshire, Connecticut

26. Diagrammatic sections showing relation of simulated heads to land surface at the Cheshire study area, Cheshire, Connecticut

27. Diagram showing particle traces and extent of local ground-water flow systems within the regional model at the Cheshire study area, Cheshire, Connecticut .........

28. Diagrams showing particle traces through CS-221, Cheshire, Connecticut

29. Diagrams showing particle traces through fractured media with fluxes from regional model

30. Diagrams showing particle traces through fractured media under pumping conditions 


\section{TABLES}

1. Discharge at streamflow-gaging stations, Cheshire study area, Cheshire, Connecticut.... 13

2. Ground-water and pond-level measurements in the Cheshire study area on June 8, 199528

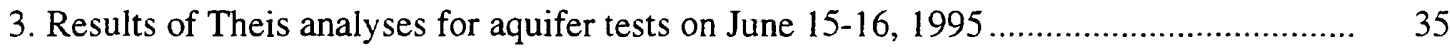

4. Results of Jacob semilogarithmic analyses for aquifer tests on June 15-16, 1995 .......... 39

\section{CONVERSION FACTORS}

\begin{tabular}{rll} 
Multiply & By & To Obtain \\
\hline inch (in) & 25.4 & millimeter \\
foot (ft) & 0.3048 & meter \\
mile $(\mathrm{mi})$ & 1.609 & kilometer \\
square ${\mathrm{mile}\left(\mathrm{mi}^{2}\right)}^{2}$ & 2.590 & square kilometer \\
foot per day $(\mathrm{ft} / \mathrm{d})$ & 0.3048 & meter per day \\
foot squared per day $\left(\mathrm{ft}^{2} / \mathrm{d}\right)$ & 0.09290 & square meter per day \\
cubic feet per second $\left(\mathrm{ft}^{3} / \mathrm{s}\right)$ & 0.02832 & cubic meter per second \\
gallon per minute $(\mathrm{gal} / \mathrm{min})$ & 0.00006309 & cubic meter per second \\
million gallons per day $(\mathrm{Mgal} / \mathrm{d})$ & 0.04381 & cubic meter per second
\end{tabular}

Temperature in degrees Fahrenheit $\left({ }^{\circ} \mathrm{F}\right)$ can be converted to degrees Celsius $\left({ }^{\circ} \mathrm{C}\right)$ as follows: ${ }^{\circ} \mathrm{C}=5 / 9\left({ }^{\circ} \mathrm{F}-32\right)$.

Sea Level: In this report "sea level" refers to the National Geodetic Vertical Datum of 1929 (NGVD of 1929)--a geodetic datum derived from a general adjustment of the first-order level nets of both the United States and Canada, formerly called Sea Level Datum of 1929.

Other abbreviations used:

ppb, parts per billion

ppt, parts per trillion

$\left(\mathrm{ft}^{3} / \mathrm{s}\right) / \mathrm{mi}$, cubic feet per second per square mile

$\mu \mathrm{S} / \mathrm{cm}$, microsiemens per centimeter at 25 degrees Celsius

cps, counts per second

ohm-m, ohm-meters 


\title{
Geohydrology and Conceptual Model of a Ground-Water-Flow System Near a Superfund Site in Cheshire, Connecticut
}

\author{
By Janet Radway Stone, Paul M. Barlow, and J. Jeffrey Starn
}

\section{ABSTRACT}

Degradation of ground-water quality has been identified in an area of the north-central part of the town of Cheshire, Connecticut. An investigation by the U.S. Geological Survey, in cooperation with the U.S. Environmental Protection Agency, was done during 1994-95 to characterize the unconsolidated glacial deposits and the sedimentary bedrock, integrate the local geohydrologic conditions with the regional geohydrologic system, and develop a conceptual understanding of groundwater flow in the study area.

A regional ground-water-flow model developed for the region near the study area indicates that perennial streams, including Judd Brook and the Tenmile River, form hydrologic divides that separate the larger region into hydraulically independent flow systems. In the local study area, synoptic water-level measurements made in June 1995 indicate that ground water near the water table flows west and southwestward from the low hill on the eastern side of the area toward the pond and wetlands along Judd Brook. Water-level data indicate that there is good hydraulic connection between the unconsolidated materials and underlying fractured bedrock.

Unconsolidated materials in the study area consist principally of glacial stratified deposits that are fine sand, silt, and clay of glaciolacustrine origin; locally these overlie thin glacial till. The glacial sediments range in thickness from a few feet to about $25 \mathrm{ft}$ in the eastern part of the study area and are as much as $100 \mathrm{ft}$ thick in the western and southern part of the study area beneath the Judd Brook and Tenmile River valleys. Fluvial redbeds of the New Haven Arkose underlie the glacial deposits in the region; in the study area, the redbeds consist of (1) channel sandstone units, which are coarse sand- stone to fine conglomerate, generally in 6 - to 15 -ftthick sequences; and (2) overbank mudstone units, which are siltstone and silty sandstone with some fine sandstone, generally in 6- to 50-ft-thick sequences. Thin-bedded zones of siltstone that are particularly fissile are present locally within the mudstone units. Rock units strike northward and dip eastward at about $20^{\circ}$. The eastward-dipping strata are cut by a consistent set of west to westnorthwest dipping, high-angle fractures. These fractures are oriented perpendicular to bedding and are present mostly in the channel sandstone units, but locally extend into the mudstone units as well.

Borehole-geophysical logging indicates that ground water flows along bedding planes in fissile zones and between fissile zones in high-angle fractures, which are perpendicular to bedding. The combined fracture types form an aquifer system in which ground water follows a stair-step flowpath, flowing horizontally through fissile zones and vertically through high-angle fractures. Heat-pulse flowmeter measurements and borehole fluid-conductivity and temperature logs indicate that only a small subset of the fissile zones and some highangle fractures are hydraulically significant. A generalized local-scale ground-water flow model based on a nonspecific, but realistic, rock and fracture geometry was developed for the study area. Simulations show that under nonpumping conditions at a hypothetical well located in the middle of the model, ground-water flow was separated into upper and lower zones in which flowpaths differed but were generally from northeast to southwest.

Several short-duration aquifer tests conducted in the study area indicate that there is good hydraulic connection in the fractures between the pumping well (CS-221) and two bedrock wells located approximately $100 \mathrm{ft}$ to the north and south 


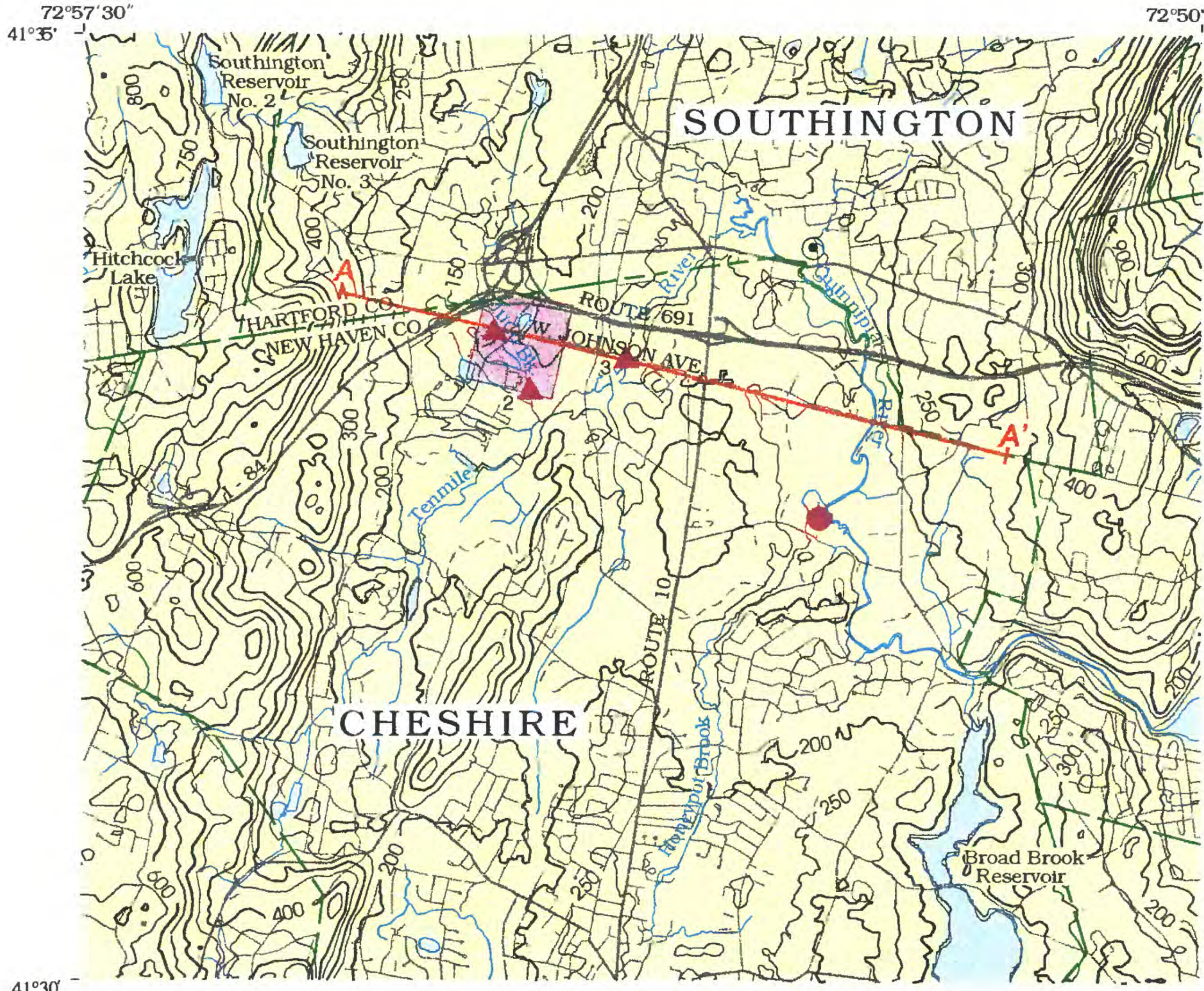
$41^{\circ} 30^{\circ}$

Base from U.S. Geological Survey digital line graph (1988) and digital elevation model (1980) from Southington and Meriden quadrangles, $1: 24,000$ scale

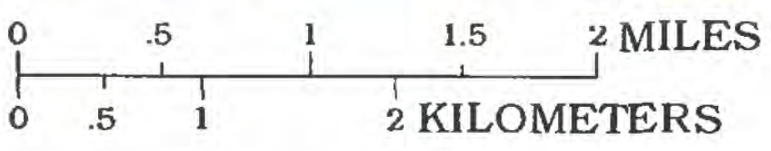

Contour interval $50 \mathrm{ft}$
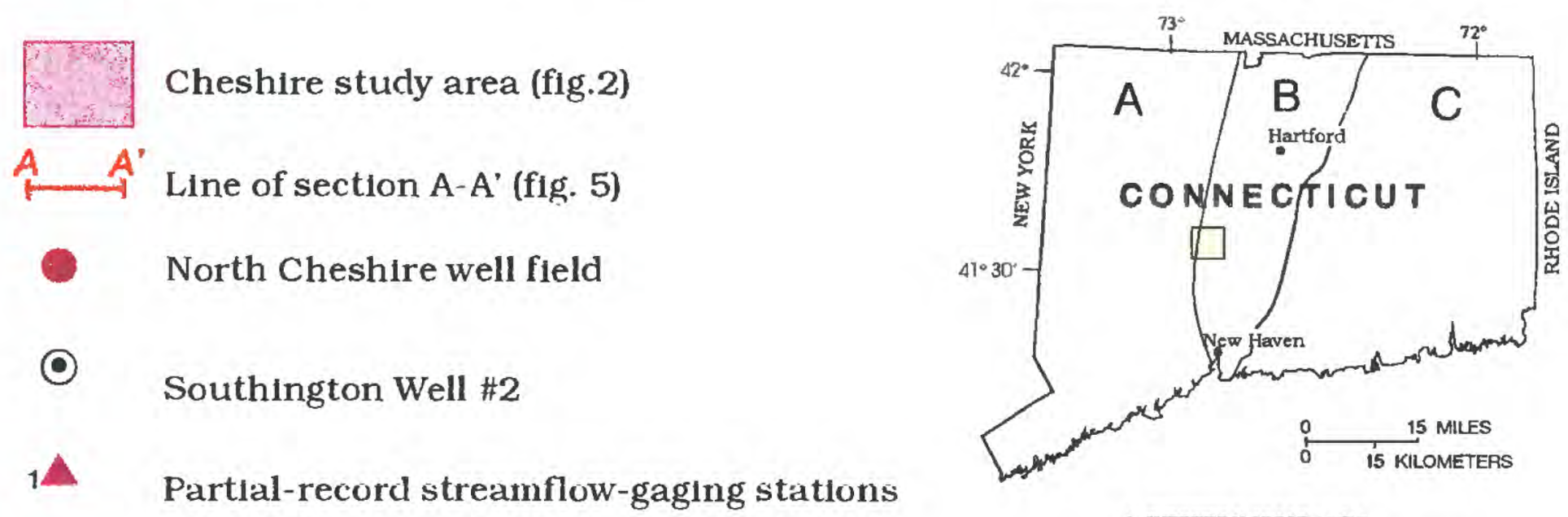

A. WESTERN HUGHLANDS

C. EASTERNCUT VALLEY LOWLAND

Figure l. Regional area, central Connecticut. 
along bedding strike. During the short duration of the aquifer tests, there was no hydraulic connection in bedrock wells located to the east, perpendicular to the strike. A range of transmissivity of 27 to $46 \mathrm{ft}^{2} / \mathrm{d}$ was calculated from the aquifer-test data for the fractured-bedrock aquifer at CS-221 and $\mathrm{TH}-2$. Individual fracture zones identified by borehole logs and heat-pulse flowmeter measurements as the source of water to these wells are calculated to have hydraulic conductivities as high as $92 \mathrm{ft} / \mathrm{d}$.

\section{INTRODUCTION}

In 1992, the U.S. Geological Survey (USGS), in cooperation with the U.S. Environmental Protection Agency (USEPA), began geohydrologic investigations of selected Superfund sites in New England. The objective was to develop a preliminary characterization and understanding of the regional and local geohydrology of the sites, primarily by using existing data, which was supplemented by a limited amount of new data. The geohydrologic characterization can be used to guide the development of Superfund Remedial Investigation/Feasibility Studies for these sites.

Degradation of ground-water quality by organic chemicals has been identified in an area of the north-central part of Cheshire, Conn. (fig. 1) (Metcalf and Eddy, 1993). The area of contamination includes two industrial sites and a single-family residence along W. Johnson Ave. (fig. 2). The property at and around $604 \mathrm{~W}$. Johnson Ave. (site A on fig. 2) was placed on the USEPA's Superfund list because of ground-water and soil degradation identified beneath the site (U.S. Environmental Protection Agency, 1992). During June 1994 through September 1995, the USGS, in cooperation with the USEPA, completed an investigation of the geohydrologic conditions near 604 W. Johnson Ave., including the single-family residence. The purpose of the investigation was to improve the understanding of the geohydrology of the unconsolidated deposits and sedimentary bedrock in the study area, to integrate the local geohydrologic conditions of the study area with the regional geohydrologic system, and to develop a conceptual understanding of ground-water flow in the study area.

\section{Purpose and Scope}

This report describes the geohydrologic conditions near an area of ground-water contamination in the north-central part of the town of Cheshire, Conn. The regional area (fig. 1), as referred to in this report, includes parts of the towns of Cheshire and Southington. The Cheshire study area (fig. 2) extends from just north and east of $604 \mathrm{~W}$. Johnson Ave. southward and westward to Judd Brook and includes areas of contamination at both industrial facilities and the single-family residence. The report summarizes the results of field work done during the 1994-95 investigation, which included geologic mapping that emphasized the interpretation of lithology and structural features of the sedimentary bedrock; drilling and installation of observation wells; surface- and borehole-geophysical surveys; measurements of streamflow and pond and ground-water levels; and four aquifer tests of short duration and low pumping rates that were done to characterize the hydraulic properties of the sedimentary bedrock and response of the bedrock ground-water-flow system to pumping. The report also describes the history of water-quality degradation in the study area as well as the results of limited water-quality sampling that was done as part of this investigation. Two conceptual models of groundwater flow were developed as part of the study to evaluate and better understand ground-water flow at the regional and local scales.

\section{Approach}

The geohydrologic characterization of the Cheshire study area is based on several methods of data collection and analysis listed below. These include an inventory of all available well and testhole data in the regional area, a geologic investigation, the installation of wells in bedrock and unconsolidated deposits, borehole-geophysical logging, a surface-geophysical survey, aquifer tests, hydrologic measurements, conceptual modeling, and water-quality sampling.

(1) Inventory-An inventory of all available records of wells and testholes in the regional study area was made to provide background information on ground-water levels, well yields, depth to bedrock, and lithologic characteristics of bedrock and surficial aquifers. The location of data points in the study area are shown on figure 2 , and the well and testhole records and lithologic logs for these points 


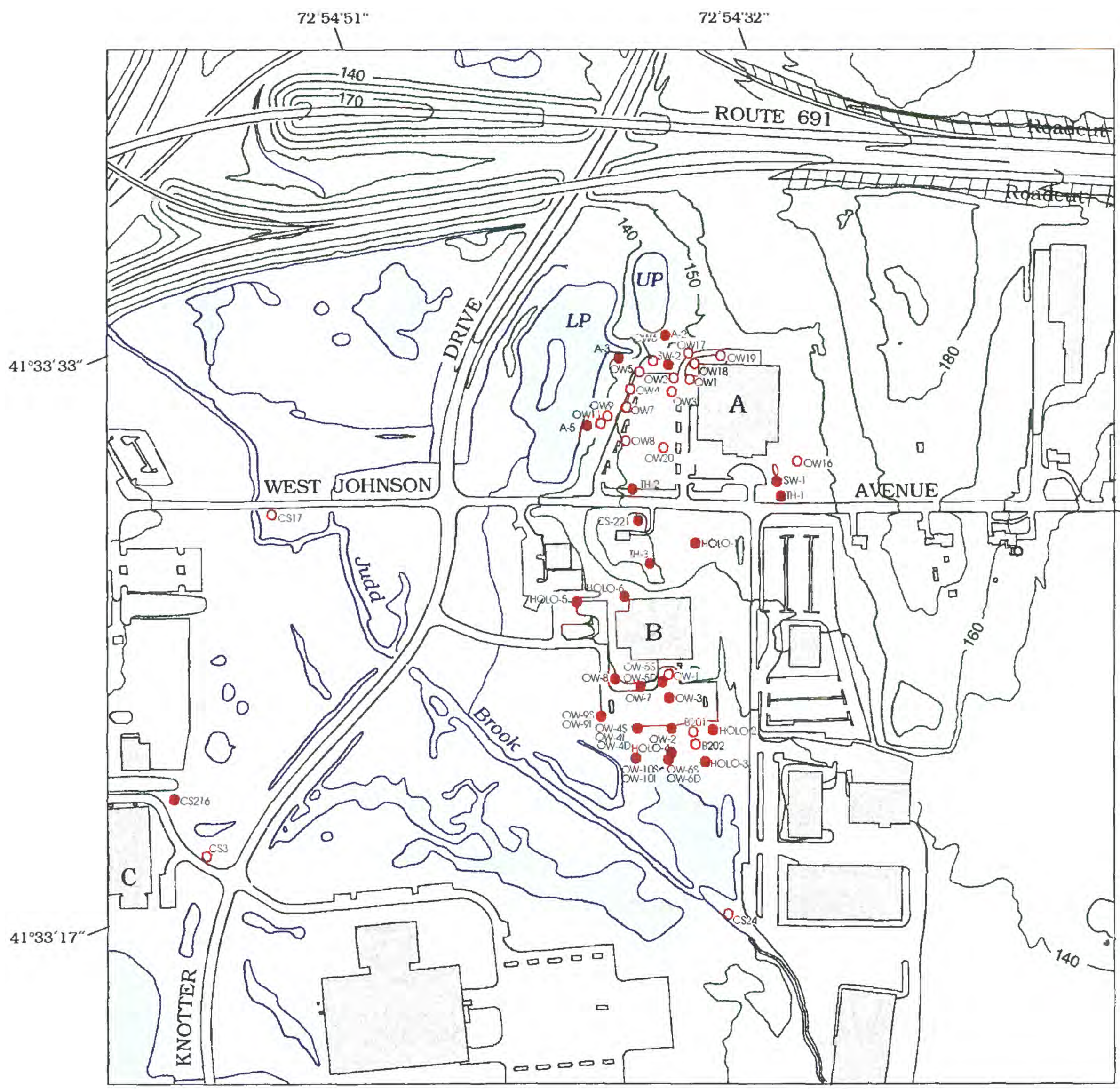

Base from U.S. Army Corp. of Engineers, Cheshire, CT, 1:1,200 scale, April 10, 1992

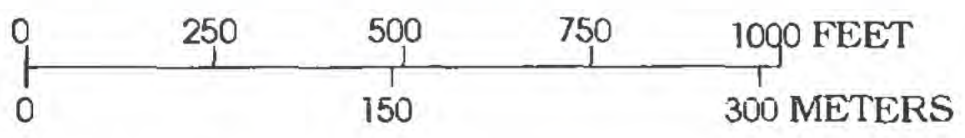

Contour interval $10 \mathrm{ft}$

EXPLANATION

- Existing monitoring wells

o Former testholes

A 604 West Johnson Avenue

B 30 Knotter Drive
C 25 Knotter Drtve

UP Upper pond

LP Lower Pond

Area of square-array resistivity survey

Figure 2. Cheshire study area, Cheshire, Connecticut. 
are included in appendix 1 . Wells and testholes are identified by local and USGS identifiers.

(2) Geologic investigations--Geologic investigations were carried out in the study area to delineate the extent and physical properties of the surficial materials and the lithology and structure of the underlying bedrock. All available exposures of surficial materials and bedrock were examined, and all lithologic logs from wells and testholes were analyzed. Geologic sections were constructed from this information.

(3) Well installation-Three deep bedrock wells (TH-1, TH-2, TH-3) and two shallow wells (SW-1 and SW-2) screened in unconsolidated material were installed by the USGS in the study area. This was done to obtain continuous bedrock core and split-spoon samples of unconsolidated materials, to provide sites for borehole-geophysical measurements, to provide additional water-level and water-quality measuring points, and to establish appropriate measuring points for hydraulic testing of the bedrock aquifer while pumping water from the existing domestic well (CS-221). The bedrock wells were installed by first augering to bedrock and casing off the unconsolidated materials with 5- or 6-in. inside-diameter (i.d.) PVC; casing was then cemented to the bedrock and grouted around the annular space. Bedrock was drilled by wire-line coring with a 4.5-in.-diameter diamond-embedded bit to a depth of about $100 \mathrm{ft}$ below land surface. This process produced an approximate 4.75 -in.diameter open borehole and 2.25-in.-diameter core. Sites for two bedrock wells were chosen along the direction of bedding strike to the north and south of the existing domestic well (CS-221). The other bedrock well was located to the east (along the dip direction) of the domestic well. Shallow wells were augered to refusal/bedrock, and 2.0-in.-i.d. PVC casing and slotted screens with 0.01 -in. openings were installed. The annular space around the casing/screen in both wells was filled with sand, and the upper few feet around the casing was grouted with bentonite.

(4) Borehole-geophysical logging-Borehole-geophysical logging was conducted to identify fractures and bedding planes that are water-bearing pathways in the bedrock, to measure flow and water quality of the borehole fluid, and to define bedrock lithology in the existing domestic well where no core was available. Borehole-geophysical logs were collected in bedrock wells $\mathrm{TH}-1, \mathrm{TH} \cdot 2$ and $\mathrm{TH}-3$, and CS-221. Types of logs collected include caliper, EM conductivity (formational resistivity), natural gamma, fluid resistivity (conductivity), fluid temperature, and heat-pulse flowmeter; data were recorded on paper and stored electronically in digital format. Acoustic -televiewer images were made in the field with a polaroid camera. Borehole television images were viewed on a color monitor during the logging and were recorded by a video-cassette recorder and stored on video tape. Copies of all recorded borehole logs are on file at the USG: Connecticut District office in Hartford, Conn.

The basic logging equipment and the procedures used in borehole logging are descrit ed by Keys (1990). More detailed information on the application of borehole-geophysical logs to geohydrologic investigations may be found in Keys (1990) and Hearst and Nelson (1985). Qualitative analysis of borehole logs collected at a site in New Jersey, where the bedrock geology is similar to that in Cheshire, is described by Williams and Conger (1990).

(5) Surface-geophysical survey-An azimuthal square-array, electromagnetic resistivity survey was done in the open field on W. Johnson Ave. east of CS-221. (See fig. 2.) This surface-geophysical technique is used to detect the presence and orientation of water-bearing zones in the fractured sedimentary bedrock aquifer. The drta are used to determine directions of anisotropy within the bedrock and can yield an estimate of the fracture porosity. Data were obtained and analyzed using the techniques described by Lane and others (1935).

(6) Aquifer tests-Four short-duratior aquifer tests were conducted to provide estimates of hydraulic properties of the fractured-bedrock aquifer and to determine its response to hydraulic stress. Aquifer tests also were done to better understand the hydraulics of the domestic well and the hydraulic connections between the water-bearing zones near the domestic well.

(7) Hydrologic measurements-Wate--level monitoring was conducted to determine groundwater levels, ground-water-flow directions in the study area, and responses of the ground-water system to natural or induced stress. Continuous waterlevel monitoring was conducted at 10 observation wells ( 6 bedrock wells and 4 wells screened in unconsolidated materials) for various lengths of 
time from December 1994 to July 1995. Water levels in observation wells were measured using a float-counterweight system connected to a punchtape recorder. Measurements were also made with a chalked steel tape with $0.01-\mathrm{ft}$ graduations to verify the accuracy of the automatic recorders. Hydrographs for the 10 wells are shown in appendix 3 . In addition, water levels were measured using an electric tape in 12 other observation wells and at the upper and lower ponds (fig. 2) for a synoptic waterlevel measurement on June 8 and during the aquifer tests in July 1995.

Stream discharge (current meter and weir measurements) was measured at two locations on Judd Brook and at one location on the Tenmile River (fig. 1). Computed stream discharges were checked and plotted to develop a rating curve for each gaging site. Stream stage and stream discharge were measured using established methods described by Buchanan and Somers (1969), Carter and Davidian (1968), and Rantz (1982). All streamflow records are on file at the USGS District office in Hartford, Conn.

(8) Conceptual modeling-Steady-state ground-water flow in the Cheshire area was simulated to determine characteristics of regional ground-water flow and to visualize the effect of geologic heterogeneity on local ground-water flow. Ground-water flow was simulated by using a numerical simulation code known as MODFLOW (McDonald and Harbaugh, 1988). The directional components of the average linear ground-water velocity were computed by use of the USGS program MODPATH (Pollock, 1994) and displayed by use of the program Tecplot ${ }^{1}$ (Amtec Engineering, Inc., 1994).

(9) Water-quality sampling-Water-quality sampling was conducted to assess water quality in the study area after drilling and installation of new wells and during aquifer testing.

\section{Overview of Water-Quality Degradation}

The quality and degradation of ground water has been investigated at several manufacturing facilities in the Cheshire study area since at least the 1980's. The results of several of these investiga-

\footnotetext{
${ }^{1}$ Use of tradenames is for identification purposes only and does not constitute endorsement by the U.S. Geological Survey.
}

tions were summarized for the USEPA in a report prepared by Metcalf and Eddy (1993). L ata presented in that report indicate that contamination in the study area is unlikely to have originated at manufacturing facilities outside the study area.

Ground-water contamination by volatile organic compounds has been documented at CS221 beginning in 1984. Contaminants identified include $1,1,1$-trichloroethane (TCA), tetrachloroethene (PCE), trichloroethylene (TCE), 1,1-cichloroethene (DCE), 1,1-dichloroethane (DCA), ethylbenzene, benzene, toluene, o-xylene, mxylene, and chloroform. Compounds detected at CS-221 in January 1986 include benzene, chloroform, TCA, carbon tetrachloride, and TCE at concentrations ranging from 0.1 to $27 \mu \mathrm{g} / \mathrm{L}$; compounds detected at CS-221 in Jure 1986 include styrene, ethylbenzene, isobutyl tenzene, chloroform, carbon tetrachloride, TCE, methylene chloride, and PCE at concentrations ranging from 0.1 to $27 \mu \mathrm{g} / \mathrm{L}$ (Metcalf and Eddy, 1993, p. 2-17). Ground-water samples analyzed by gas chromatograph during this investigation showed no detection of either PCE or TCE, but did show detections for DCE (0.6-1.2 $\mu \mathrm{g} / \mathrm{L})$ (S. Clifford, U.S. Environmental Protection Agency, written commun., 1994; 1995). CS-221 is completed in bedrock and probably was drilled before April 1960. The well was taken out of service as a domestic supply well in December 1987. Prior to our investigation, the last time ground-water samples were collected from the well was in August 1987.

Contamination at the $604 \mathrm{~W}$. Johns on Ave. property has been associated with a 10,000 -gallon underground No. 4 fuel oil storage tank formerly located near the two ponds (approximately $500 \mathrm{ft}$ north-northeast of CS-221) (Metcalf and Eddy, 1993). The No. 4 fuel oil tank had replaced a previously used tank at the site, which perhaps $\mathrm{r}$ ad contained No. 2 fuel oil (NUS Corporation, 1986a). Other possible sources of contamination include the lower pond on the property, into which wastewater effluent from manufacturing processes at the site was allegedly discharged prior to 1983 (Metcalf and Eddy, 1993, p. 2-3); an underground drain pipe that extends from two in-ground concrete pits inside the building to the lower pond (Met:alf and Eddy, 1993, p. 2-5); surface dumping that ray have occurred in areas surrounding the building as evidenced by stained soil (Metcalf and Eddy, 1993. 
p. 3-3); and an abandoned septic system under the parking lot on the property. The facility was placed on the public sewer system in 1983 (W. Curry, Phillips Automotive Electronics Corporation, oral commun., February 1996). Ground-water contamination north of W. Johnson Ave. was first documented in 1980 (Ground Water Associates, 1980). Ground water has been contaminated by various volatile organic compounds, including TCA, methylene chloride, DCA, DCE, PCE, heptane, and acetone, in addition to hydrocarbon contamination tentatively identified as No. 2 fuel oil. Previous studies have documented ground-water contamination only in unconsolidated deposits.

Contamination south of W. Johnson Ave. has been associated with a former 1,000-gallon underground storage tank and a former industrial leachfield (approximately $500 \mathrm{ft}$ south of CS-221) (Metcalf and Eddy, 1993). Waste oil, waste electrolytic solution, and spent solvents were stored in the underground storage tank between 1978 and 1983. The tank was removed in July 1986. During removal, two openings approximately 2 in. by $2.5 \mathrm{ft}$ were noted on each end of the tank, and a gray sludge at the bottom of the tank exhibited a characteristic solvent odor. A soil-vapor extraction system was operated at the site of the former underground storage tank from August 1991 through November 1993 to remediate volatile organic contamination of the unsaturated zone. Ground-water contamination by volatile organic compounds has been documented since July 1986. Contaminants identified in the unconsolidated deposits and bedrock include PCE, TCE, methylene chloride, chloroform, DCE, 1,2-DCE, TCA, and DCA. Contamination by PCE, TCA, DCE, and DCA also has been documented at well HOLO-5 (fig. 2). Concentrations greater than $10,000 \mu \mathrm{g} / \mathrm{L}$ PCE, 3,500 $\mu \mathrm{g} / \mathrm{L}$ TCE, and $5,000 \mu \mathrm{g} / \mathrm{L}$ chloroform have been found in ground water at 30 Knotter Dr. Concentrations of PCE and TCE in ground-water samples collected south of W. Johnson Ave. in February 1995 exceeded State and Federal maximum contaminant levels for drinking water at several wells (ALTA Environmental Corporation, 1995, p. 2-3).

On May 3, 1995, water samples were collected from wells SW-1, SW-2, TH-1, TH-2, TH-3, and CS-221. Samples were collected using a depthspecific bailer from $\mathrm{TH}-1$ at a depth of $60 \mathrm{ft}$; from
TH-2 at depths of 15,39 , and $85 \mathrm{ft}$; from TH-3 at a depth of $22 \mathrm{ft}$; and from CS-221 at depths of 49 and $64 \mathrm{ft}$. Samples were collected at SW-1 and SW-2 at an approximate depth of $15 \mathrm{ft}$. The depths in bedrock wells were selected to be adjacent to fractures in the wellbore as seen on the geophysical logs, and at mid-screen in the shallow wells. All samples were analyzed on site using a portable gas chromatograph (T.M. Spittler, U.S. Environmental Protection Agency, written commun., 1995). The pattern of peaks on the chromatograms for samples from SW-1 and SW-2 were observed in the field to be almost identical, indicating that perhaps the same history of degradation had taken place at both wells. The peaks on the chromatograms, which indicate concentration, were about three times higher in SW-2 than in SW-1. Analysis of samples from SW-1 on May 5, 1995, in the laboratory using gas chromatography/mass spectroscopy indicated the presence of a large number of complex aromatic molecules that are typical of light fuel oils, such as No. 2 or diesel fuel oil. There were no observable peaks on any of the chromatograms at the 100-ppt level, except for the sample from $\mathrm{TH}-1$, which had no observable peaks at the 100-ppb level. The sample from $\mathrm{TH}-1$ was not run at a higher sensitivity.

\section{Acknowledgments}

The authors thank D.M. Fusco, Cheshire, Connecticut resident, for permission to conduct investigations on her property; Kelly Meloy and Evan Glass, ALTA Environmental Corporation, for information on their ongoing investigations at the industrial facility at $30 \mathrm{Knotter}$ Dr. and assistance in measuring water levels during the synoptic waterlevel measurement of June 1995; and Jane Dolan, U.S. Environmental Protection Agency, for her assistance in the field. They also thank the following USGS employees: John Organek, for drilling and installing the bedrock wells; David Loos, for water-level monitoring and preparation of the hydrographs in this report; George Casey, for assistance with coring and preparation of digital coverages; Patrick Craft, for assistance with coring; Kevin Knutson and Richard Hodges, for boreholegeophysical logging; Bruce Hansen, for conducting aquifer tests; and John Lane, for surface-geophysical surveying. 


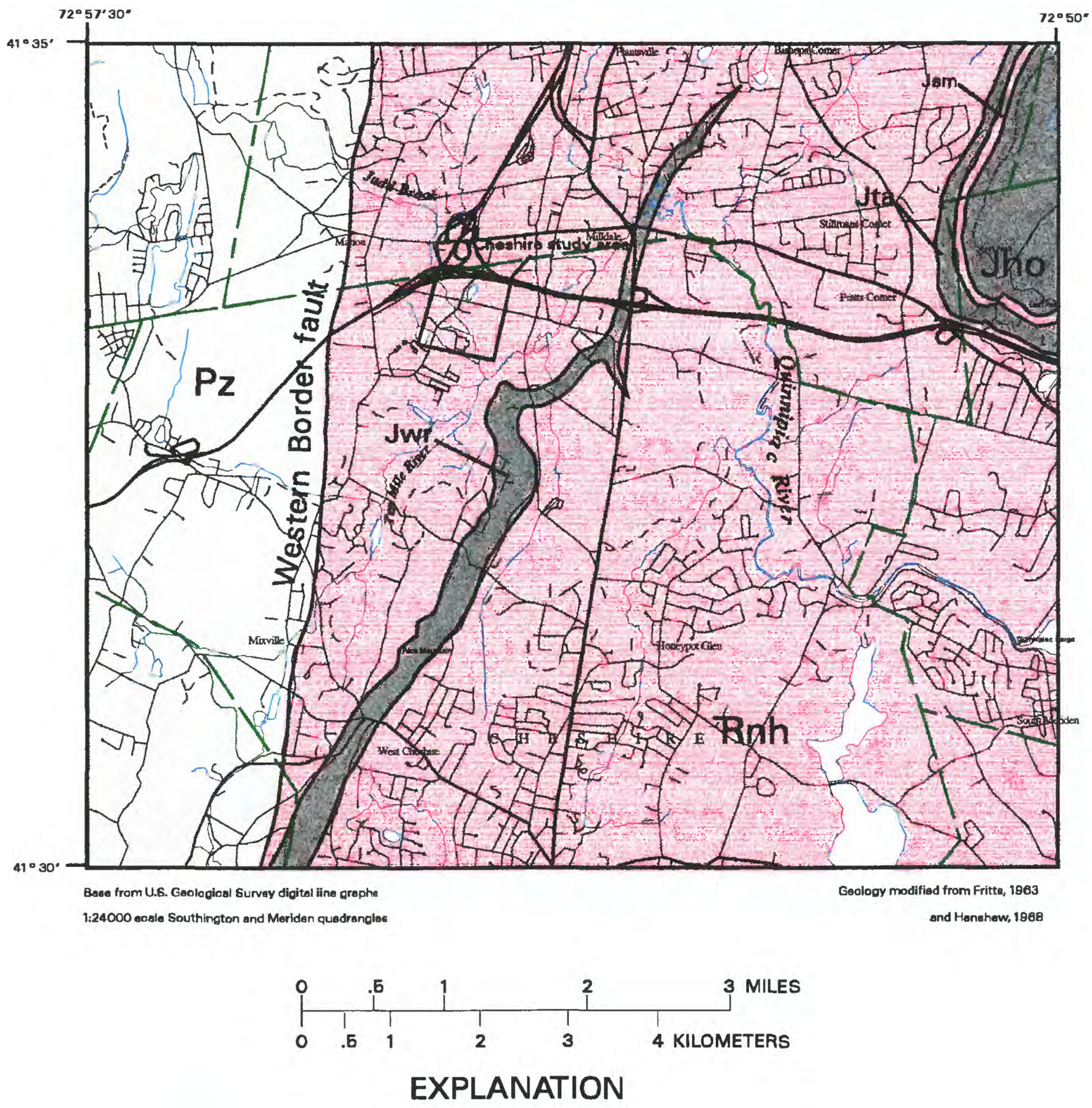

\begin{tabular}{|c|c|}
\hline ista. & Holyoke Basalt, Jurassic \\
\hline Jem & Shuttle Meadow Formation. Jurassic \\
\hline & Talcott Basalt, Jurassic \\
\hline Int & West Rock Diabase, Jurassic \\
\hline Finh & New Haven Arkose. Triassic \\
\hline$P_{z}$ & Crystalline bedrock, Paleozoic \\
\hline
\end{tabular}

Figure 3. Regional bedrock geology, Cheshire area, central Connecticut. 


\section{REGIONAL SETTING}

The regional area (fig. 1) is located in the central Quinnipiac River Basin. Basic hydrogeologic data for the area is presented in Mazzaferro (1973); Mazzaferro and others (1979); and Haeni and Anderson (1980). The regional bedrock geology has been described on published geologic maps (Fritts, 1963; Hanshaw, 1968; Rodgers, 1985). Detailed lithology and stratigraphy of two outcrops (more than 1,000 ft long) along Rt. 691 and Rt. 84 just north of the $604 \mathrm{~W}$. Johnson Ave. property are described by McInerney (1993) and Hubert and others (1978). Regional surficial geology has been described in published geologic maps (LaSala, 1961; Hanshaw, 1962; Stone and others, 1992) and in a report on the Quinnipiac Lowland (Stone and others, 1985).

\section{Physiography and Geology}

The regional area (fig. 1) is located near the western border of the Connecticut Valley Lowland, which is also known as the Hartford Basin, and is underlain by sedimentary and igneous rocks of Mesozoic age (fig. 3). The Quinnipiac River flows southward within a broad (4- to 8-mi wide), northsouth trending valley or lowland, called the Quinnipiac lowland. The Quinnipiac lowland is bounded to the west by the Western Highlands, which are underlain by crystalline rocks of Paleozoic age (fig. 3 ), and reach altitudes greater than $750 \mathrm{ft}$. The lowland is bounded to the east by linear traprock ridges (Jurassic-age basalt) that reach altitudes between 700 and $1,000 \mathrm{ft}$. The Quinnipiac lowland is underlain predominantly by Late Triassic-age sedimentary bedrock, which forms low hills at altitudes of 200 to $300 \mathrm{ft}$ above sea level and deep bedrock valleys, which are locally below sea level. The bedrock valleys are partially filled with thick glacial stratified deposits (stratified drift), laid down by glacial meltwater.

The Quinnipiac River is incised almost entirely into glacial stratified deposits (fig. 4). The Quinnipiac River and parts of tributary streams, such as Tenmile River and Judd Brook, occupy floodplain surfaces at altitudes between 120 and $140 \mathrm{ft}$. Bedrock valleys in the Quinnipiac lowland are glacially overdeepened and are filled with gla- cial deposits (principally stratified deposits) to altitudes of 150 to $200 \mathrm{ft}$ (see cross-section A-A', fig. 5).

The most extensive bedrock unit in the area is the New Haven Arkose, a red-brown to gray-brown siltstone, sandstone, and conglomerate of Late Triassic age (fig. 3). These sedimentary rocks are predominantly fluvial floodplain deposits, which include overbank mudstones that consist of redbrown sandy siltstone and silty sandstone, and channel sandstones that are gray-brown, coarser sandstone and pebble conglomerate. The mineral composition of sediments and cements of Hartford Basin sandstones, including the New Haven Arkose, has been described by Hubert and others (1992). The rocks are arkosic with subequal amounts of quartz and feldspar and lesser amounts of other rock fragments. The grains are stained by hematite (iron-oxide), which produces the pervasive red-brown color of this rock. Carbonate cement (principally calcite) and overgrowths on feldspar grains constitute an average 13 percent of the total rock volume; these contribute significantly to the relatively low primary porosity of the rock. Bedding strikes northward and dips eastward $10^{\circ}$ to $20^{\circ}$ in most exposures.

Bedrock in the northeastern part of the area consists of three stratigraphically younger units that are of Jurassic age: Talcott Basalt, Shuttle Meadow Formation, and Holyoke Basalt (fig. 3). The Talcott and Holyoke Basalts are east-dipping extrusive lava flow units consisting of dark gray tholeiitic basalt; the Shuttle Meadow Formation is a thin sedimentary unit between the basalts. A narrow zone in the central part of the area is underlain by the West Rock Diabase, which is an intrusive igneous rock unit similar in character to the basalt units. The western edge of the area is underlain by metamorphic crystalline rocks, which are gneisses and schists of Paleozoic age. All the bedrock in the area is extensively fractured.

The unconsolidated materials overlying bedrock in the area (fig. 4) consist predominantly of glacial sediments laid down during advance and retreat of the last (late Wisconsinan) ice sheet. A relatively thin layer of glacial till, deposited directly by glacial ice, discontinuously overlies the bedrock surface. In some places, till is absent and the bedrock surface is directly overlain by stratified 


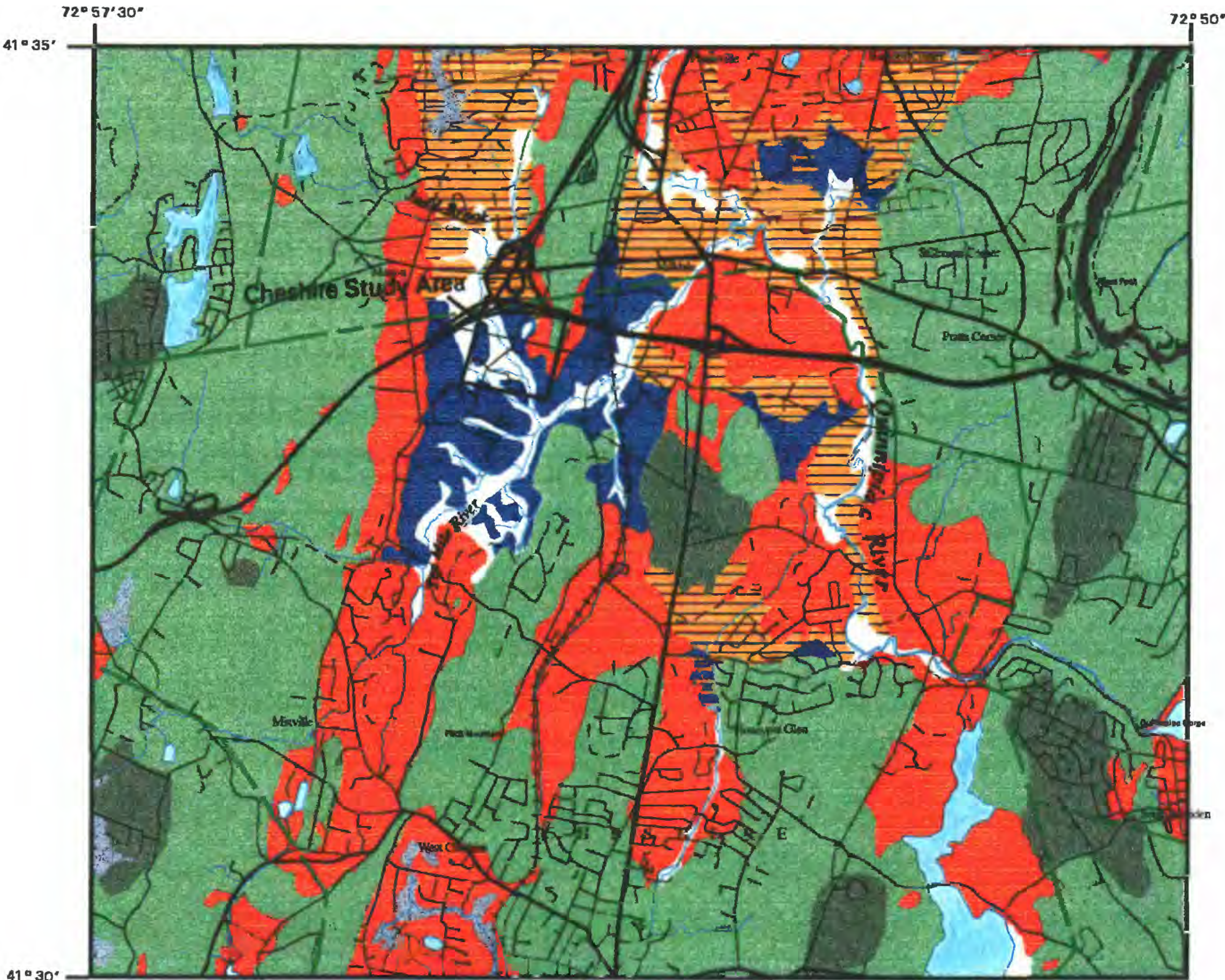

Buse from U.8. Oeologioel Burvey digital line grephe

Geologr modified from Stone and othern, 1992

1:24000 scele Bouthington and Meriden quedrengla

\begin{tabular}{|c|c|c|c|c|c|}
\hline 0 & & & 1 & 2 & 3 MILES \\
\hline & T & $T$ & T & 1 & 1 \\
\hline 0 & .6 & 1 & 2 & 3 & 4 KILOMETERS \\
\hline
\end{tabular}

Postglacial Depositg

Water body

Floodplain alluvium

Swamp deposits

Talue

Glacial Stratified Deposits

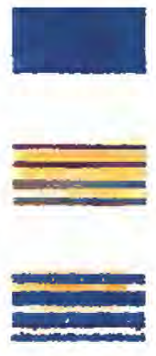

Fino-grained deposite, including Very Fine Sand, Silt, and Clay

Coarse-grained daposite overlying Fine-grained deposits

Fine-grained deposite overlying Coarbe-grained daposite

Glecial lca-laid Depoeita

Till, generally lees than 10-15 ft thick, includee areas of bedrock outcrops

Till, greater than 10-15 ft thick

Coarse-grained depoeite, including Gravel,

Sand and Gravel, and Sand

Figure 4. Regional surficial geology, Cheshire area, central Connecticut. 

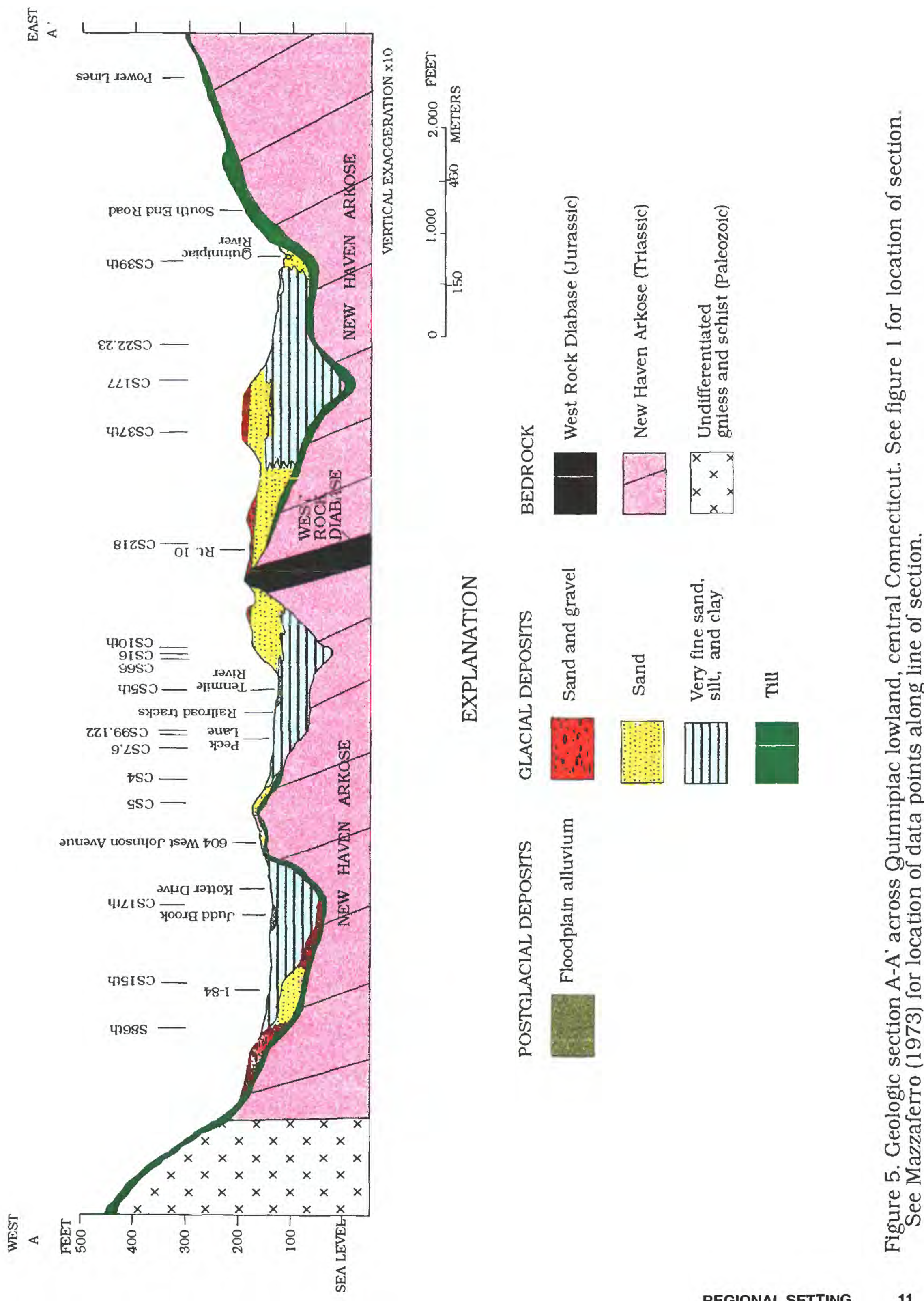

芯

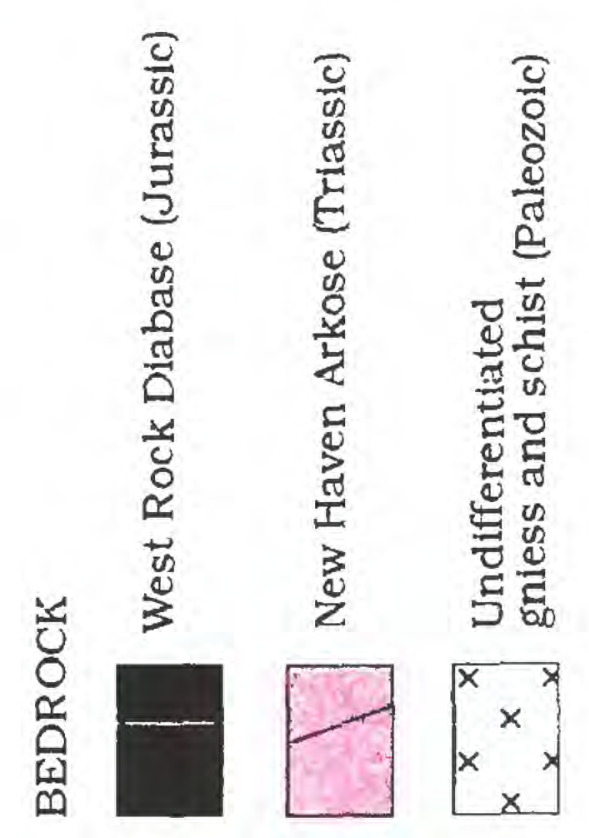

등

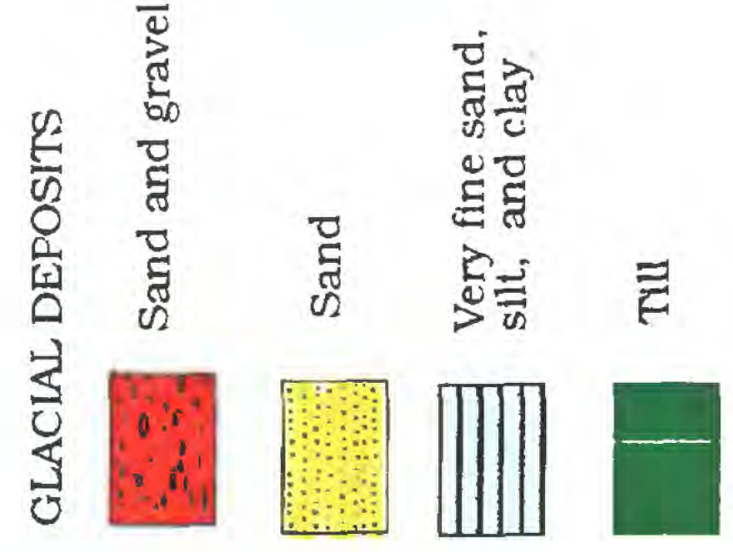

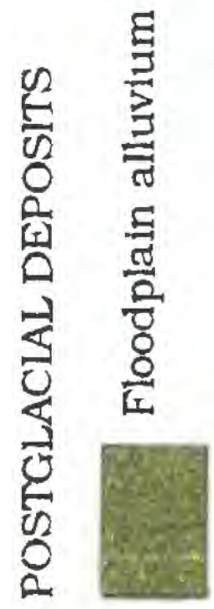


deposits (fig. 5). Till in the area was deposited predominantly as lodgment till beneath continental ice sheets during the late Wisconsinan and earlier (Illinoian) glaciations. Its color and lithology closely resemble the underlying sedimentary bedrock from which it was derived. The till is red-brown and consists of a nonsorted, nonlayered mixture of grain sizes with a matrix of 50 to 60 percent sand, 30 to 40 percent silt, and 10 to 15 percent clay; larger rock fragments (clasts) generally constitute 10 to 20 percent of the total volume of the material (Melvin and others, 1992a). This red-brown till is relatively hard, dense, and compact. This is partly due to its subglacial origin but also to its silt and clay content, which is higher than that of the gray tills of the eastern and western highland areas of Connecticut.

Stratified deposits are relatively thick and extensive in the Quinnipiac valley and the valleys of Tenmile River and Judd Brook (figs. 4 and 5). These deposits consist of both coarse-grained and fine-grained glaciolacustrine deposits. In this part of the Quinnipiac lowland, glacial Lake Southington controlled meltwater deposition of deltaic and lake-bottom sediments (Stone and others, 1985). The water level of the glacial lake was at an altitude of about $200 \mathrm{ft}$, and deltaic sands and gravels are present at this level in the area. Glacial lake-bottom surfaces, underlain by fine-grained sediments (very fine sand, silt, and clay), are at altitudes of 130 to $150 \mathrm{ft}$ in the Tenmile River, Judd Brook, and Quinnipiac River valleys. Coarse-grained stratified deposits in this area are commonly glacial-lake deltas consisting of thin sand and gravel overlying thicker sand; the sand overlies and interfingers with the fine-grained glaciolacustrine deposits. In some places, coarse-grained stratified deposits underlie fine-grained deposits and are related to ice-marginal deposition associated with older glacial meltwater sequences to the south in the valley. This is the case in the Honeypot Brook valley where the North Cheshire well field is located (fig. 1). Stone and others (1992) show a regional north-south geologic section that depicts the subsurface distribution of coarse- and fine-grained stratified deposits in this region.

\section{Hydrology}

The regional hydrology of a $363-\mathrm{mi}^{2}$ area in south-central Connecticut drained principally by the Quinnipiac River and six smaller rivers has been described by Mazzaferro and others (1979). Hydrologic data that are relevant to the Cheshire study area are available from that report, as well as in Mazzaferro (1973, 1975), Haeni and Anderson (1980), and Leggette, Brashears, and Graham (1992). Mean annual precipitation in the basin for the 1979 report reference period (October 1930 through September 1960) has been estimated to be 47.34 in. Mean annual runoff for the same period was estimated to be $25.98 \mathrm{in}$. (or $1.91\left(\mathrm{ft}^{3} / \mathrm{s}\right) / \mathrm{mi}^{2}$ of drainage area), and evapotranspiration, which is calculated as the difference between mean annual precipitation and mean annual runoff, is 21.36 in. Precipitation exceeds evapotranspiration in late autumn and winter, so that more water is stored in streams, impoundments, aquifers, and soils. Precipitation generally is less than evapotranspiration in late spring and summer, so less water is stored.

The Quinnipiac River, Tenmile River, Honeypot Brook, and Judd Brook drain land and receive discharge from the ground-water-flow system in the area. Judd Brook is a tributary to the Tenmile River; the confluence of Judd Brook and Tenmile River is about 3,000 ft south-southeast of the $604 \mathrm{~W}$. Johnson Ave. property (fig. 1). The headwaters of Judd Brook are lakes in the Western Highlands. Water is diverted from these lakes (Southington Reservoirs 1, 2, and 3) by the Southington Water District (Jim Geis, Southington Water Department, oral commun., 1994); these diversions may affect streamflow in Judd Brook. The Tenmile River joins the Quinnipiac River approximately $1.8 \mathrm{mi}$ northeast of the confluence of Judd Brook and Tenmile River.

Continuous streamflow records for the Quinnipiac River are collected at two USGS streamflowgaging stations outside the area-at Southington (USGS station $01195490 ; 1.5 \mathrm{mi}$ north of the area shown in fig. 1) and at Wallingford (USGS station $01196500 ; 3.5$ mi south of the area shown in fig. 1). Streamflows have been measured at the Southington gage since November 1987 and at the Wallingford gage since October 1930; records of daily discharge have been published in the annual series of USGS 
Table 1. Discharge at streamflow-gaging stations, Cheshire study area, Cheshire, Connecticut

[All discharge measurements are in cubic feet per second; USGS, U.S. Geological Survey;

D.A., drainage area, $\mathrm{mi}^{2}$, square miles; --, not measured]

\begin{tabular}{|c|c|c|c|}
\hline Date of measurement & $\begin{array}{l}\text { Judd Brook at W. } \\
\text { Johnson Ave. } \\
\text { (USGS 01196083; } \\
\text { site } 1 \text { on figure 1) } \\
\text { D.A. } 5.12 \mathrm{mi}^{2}\end{array}$ & $\begin{array}{c}\text { Judd Brook at } \\
\text { 30 Knotter Dr. } \\
\text { (USGS 01196085; } \\
\text { site } 2 \text { on figure 1) } \\
\text { D.A. } 5.59 \mathrm{mi}^{2}\end{array}$ & $\begin{array}{l}\text { Tenmile River at W. } \\
\text { Johnson Ave. } \\
\text { (USGS 01196095; } \\
\text { site } 3 \text { on figure 1) } \\
\text { D.A. } 16.9 \text { mi }^{2}\end{array}$ \\
\hline $07-20-94$ & 1.6 & 1.8 & 6.6 \\
\hline $09-08-94$ & 3.1 & 3.0 & 13 \\
\hline $10-20-94$ & 4.0 & 4.1 & 15 \\
\hline $01-25-95$ & 16 & - & -- \\
\hline $03-08-95$ & 12 & 12 & 44 \\
\hline $04-17-95$ & 7.6 & -- & -- \\
\hline $05-16-95$ & 6.9 & 6.5 & 29 \\
\hline $06-07-95$ & 4.7 & 3.5 & 12 \\
\hline
\end{tabular}

data reports titled "Water Resources Data for Connecticut." The mean annual flow determined for the gaging station at Southington for the period of record (water years ${ }^{2} 1988-94$ ) is $35.1 \mathrm{ft}^{3} / \mathrm{s}$; annual runoff during this period was 27.43 in. $\left(2.02\left(\mathrm{ft}^{3} / \mathrm{s}\right) / \mathrm{mi}^{2}\right)$, which is close to the basin average of 25.98 in. cited above. Streamflow at the Wallingford station is regulated by reservoirs and mills upstream of the station.

Three partial-record streamflow-gaging stations (fig. 1) were established in July 1994 to provide data on flow characteristics in the study area. Two stations were established on Judd Brook-one at W. Johnson Ave. (USGS 01196083) and one at the south end of the 30 Knotter Dr. property (USGS 01196085). The third station (USGS 01196095) is located on Tenmile River, about 3,500 ft below the confluence with Judd Brook. Drainage areas for the three stations are shown in table 1 . Using an average surface runoff value of $1.91\left(\mathrm{ft}^{3} / \mathrm{s}\right) / \mathrm{mi}^{2}$ for the Quinnipiac River Basin, mean annual streamflow

\footnotetext{
${ }^{2}$ Water year is the 12 -month period, October 1 through September 30 . It is designated by the calendar year in which it ends and which includes 9 of the 12 months. Thus, the year ending September 30 , 1988 is called the "1988 water year."
}

for the three stations is estimated to be $9.8 \mathrm{ft}^{3} / \mathrm{s}$ at station $01196083,10.7 \mathrm{ft}^{3} / \mathrm{s}$ at station 01196085 , and $32.3 \mathrm{ft}^{3} / \mathrm{s}$ at station 01196095 .

Several discharge measurements were made at these stations (table 1). Measured discharge at the two stations on Judd Brook ranged from 1.6 to $16 \mathrm{ft}^{3} / \mathrm{s}$ during the study. Measured discharge at the station on the Tenmile River ranged from 6.6 to $44 \mathrm{ft}^{3} / \mathrm{s}$ during the study; the higher discharge measurements on Tenmile River reflect the larger d-ainage area of the Tenmile River station than that of either Judd Brook station. Measured discharge was largest during January and March 1995 and smallest during July 1994. Because of the small difference in drainage areas between the two statiors on Judd Brook, it is difficult to conclude from the discharge data whether Judd Brook is gaining or lcsing over the reach between partial-record gages. Ground-water-level measurements, described later in the report, indicate that Judd Brook is an area of ground-water discharge and therefore, should be gaining over the reach. Whether or not Judd Brook is gaining or losing (or both, depending on the time of year), the data shown in table 1 indicate that this total gain or loss is likely to be relatively small and difficult to quantify. 
The primary source of recharge to the ground-water-flow system is precipitation; recharge from private septic systems may be a local secondary source. Recharge to glacial stratified deposits in the Quinnipiac River Basin has been estimated by Mazzaferro and others (1979) using streamflow records. The rate of ground-water outflow from drainage areas in Connecticut determined by streamflow analyses has been correlated to the percentage of total basin area underlain by glacial stratified deposits. Maximum rates of ground-water outflow, for basins underlain by 100 percent stratified deposits, have been estimated to be about 95 percent of total surface runoff, or, for the Quinnipiac River Basin, about 24.7 in. About 40 percent of the drainage basin of the two Judd Brook discharge stations is underlain by stratified deposits. Using the estimation technique described in Mazzaferro and others (1979), this would correspond to an annual ground-water outflow rate from the area drained by Judd Brook equal to 60 percent of annual surface runoff, or about 15.6 in. of natural recharge to the Judd Brook drainage basin per year. Natural recharge from precipitation directly to till and bedrock of the Quinnipiac River Basin is estimated to range from 7 to $10 \mathrm{in} / \mathrm{yr}$ (Mazzaferro and others, 1979) or about 27 to 38 percent of surface runoff for the period 1930-60.

Reported yields of 64 wells screened in stratified drift in the Quinnipiac River Basin range from 14 to $2,000 \mathrm{gal} / \mathrm{min}$, with a median yield of $500 \mathrm{gal} / \mathrm{min}$ (Mazzaferro and others, 1979). The median reported yield of 13 wells screened in stratified drift in the Cheshire study area is $100 \mathrm{gal} / \mathrm{min}$, but the range is 4 to $1,750 \mathrm{gal} / \mathrm{min}$. The yields of wells screened in till in Connecticut are low and typically are marginally adequate for the domestic needs of most households (Mazzaferro and others, 1979). Reported yields of 925 wells that tap sedimentary bedrock in the Quinnipiac River Basin range from 0 to $305 \mathrm{gal} / \mathrm{min}$, with a median yield for all wells of $10 \mathrm{gal} / \mathrm{min}$ (Mazzaferro and others, 1979). Reported yields of 31 wells that tap sedimentary bedrock in the regional area range from 1.5 to $75 \mathrm{gal} / \mathrm{min}$, also with a median yield of $10 \mathrm{gal} / \mathrm{min}$.

The hydraulic properties of glaciolacustrine deposits in the study area have not been previously measured. In the Quinnipiac River Basin, Mazza- ferro and others (1979, p. 41) report extimated hydraulic conductivities of $5 \mathrm{ft} / \mathrm{d}$ for very fine sand, silt, and clay. Stratigraphically lower glaciolacustrine sediments consist of varved silt and clay. Melvin and others (1992a) report mean hydraulic conductivities for varved clay, measured using laboratory methods, ranging from a vertical h.:draulic conductivity of $0.001 \mathrm{ft} / \mathrm{d}$ to a horizontal hy draulic conductivity of $0.82 \mathrm{ft} / \mathrm{d}$. Barlow (1994, p. 10) reported horizontal hydraulic conductivities of $1.6 \times 10^{-4}$ to $1.1 \times 10^{-3} \mathrm{ft} / \mathrm{d}$ and vertical h:draulic conductivities of $7.0 \times 10^{-5}$ to $1.0 \times 10^{-3} \mathrm{ft} / \mathrm{d}$ for three samples of glaciolacustrine deposits from Cape Cod, Mass., that consist of more than 91 percent silt and clay.

Coarse-grained stratified drift, consisting of sand and sand and gravel deposits, is present in the regional area both at the surface, and in the subsurface beneath glaciolacustrine silt and clay. Well records indicate that buried coarse-grained stratified deposits can produce significant y'elds of water. Horizontal hydraulic conductivity of coarsegrained stratified deposits estimated from available hydrogeologic information for the Quinnipiac River Basin and other areas in the glaciated northeastern United States is 100 to $650 \mathrm{ft} / \mathrm{d}$ (Mazzaferro and others, 1979; Randall and others, 1988; Leggette, Brashears, and Graham, Inc., 1992).

Well CS-216 (fig. 2), which is about $1,500 \mathrm{ft}$ southwest of the domestic well (CS-221), is screened in sand and gravel beneath $63 \mathrm{ft}$ of fine sand, silt, and clay. The well was under artesian conditions when first drilled and flowed at a rate of about $10 \mathrm{gal} / \mathrm{min}$; the reported yield of the well is $400 \mathrm{gal} / \mathrm{min}$ (R.J. Viselle, Sima Drilling Co., written commun., July 1994). Currently (February 1996), about 70,000 gal are pumped each w'ork day ( 5 days per week) over a 12-hour period; th? well is off during other times (Ray Roberts, Erickson Metals, oral commun., February 1996). Ground-waterlevel data collected in several wells in th e study area as part of this investigation and discus ed later in this report did not show any daily cyclic fluctuations, which might have been indicative of pumping at well CS-216. As shown on figure 4, the well most likely pumps from buried coarse-grained deposits that are recharged west of the well between the well and the Western Highlands. There are several reasons why pumping at well CS-216 is very unlikely 
to affect ground-water flow and contaminant transport at the study site. These include: the likely pinchout of buried coarse material between the well and the study site (figs. 4 and 5); the likely westward recharge area to the well; the lack of obvious response in water levels at wells within the study site to daily pumping cycles; and the large distance of the well from the area of contamination.

Melvin and others (1992a) summarized hydraulic properties of tills derived from sedimentary rocks of central Connecticut and west-central Massachusetts. They reported horizontal hydraulic conductivities of these tills of $7.9 \times 10^{-4}$ to $3.4 \mathrm{ft} / \mathrm{d}$ and vertical hydraulic conductivities of $5.1 \times 10^{-4}$ to $3.4 \mathrm{ft} / \mathrm{d}$. The hydraulic conductivity of till derived from sedimentary rocks is typically about $8.5 \times 10^{-3} \mathrm{ft} / \mathrm{d}$ (Melvin and others, 1992b). Values reported by Melvin and others (1992a; 1992b) agree with those cited by other investigators (Mazzaferro and others, 1979; Randall and others, 1988; Stephenson and others, 1988). Melvin and others (1992a; 1992b) also report a porosity of these tills that ranges from 18 to 40.1 percent, with a typical value of about 25 percent.

Estimates of the hydraulic properties of sedimentary bedrock similar to that in the study area were made in Durham, Conn. and indicate a range of transmissivity from less than 1 to about $1,700 \mathrm{ft}^{2} / \mathrm{d}$, a storativity generally of about $10^{-4}$, an intergranular porosity of about 5 percent, and fracture porosity estimated at two sites to be 1.1 and 2.7 percent (Melvin and others, 1995).

\section{Water Use}

Residences in the immediate vicinity of the study area, including the residence at the site of CS-221, receive public water from the South Central Connecticut Regional Water Authority (RWA). In addition, private wells operate in the area, including a large-capacity well (well CS-216, fig. 2) that pumps an average of about $70,000 \mathrm{gal} / \mathrm{d}$ for noncontact cooling at the Erickson Metals Corporation (Ray Roberts, Erickson Metals Corporation, oral commun., 1996). This well is screened in coarsegrained stratified drift. The RWA operates a cluster of five public-supply wells at the North Cheshire Well Field about 2 mi southeast of the study area (fig 1). These wells are screened in coarse-grained stratified drift and pumped an average of $1.53 \mathrm{Mgal} / \mathrm{d}$ during 1993 (Bob Toring, South Central Connecticut Regional Water Authority, written commun., 1994).

The Southington Water Department service area includes only a small part of the town of Cheshire; that area is located about 1 mi ncrthwest of the study area (Jim Geis, Southingtor Water Department, oral commun., 1994). The Scuthington Water Department operates a public-supply well (Southington \#2) about 1.7 mi northeast of the study area (fig. 1). An average of $0.63 \mathrm{Mgcl} / \mathrm{d}$ was pumped from this well during July 1992 through June 1993 (Jim Geis, Southington Water Department, oral commun., 1994).

Many, but not all, residences and commercial facilities along W. Johnson Ave. and Knotter Dr. are connected to the town sewer system. The property at $604 \mathrm{~W}$. Johnson Ave. was connected to the sewer system in 1983, and the property at 30 Knctter Dr. was connected in 1981 (Len Cunningham, Town of Cheshire Building Department, oral commun., 1996). There is no sewer connection at the site of the domestic well (CS-221); wastewater is discharged to a septic system at the back of the residence.

\section{GEOHYDROLOGIC CONDITIONS IN THE CHESHIRE STUDY AREA}

The Cheshire study area (fig. 2 ) is situated on the western side and at the southern end of a low bedrock hill in the Quinnipiac lowland; desp bedrock valleys filled with glacial lake sediments lie to the west, south, and east of this hill (Mazzaferro, 1975). To the west of the study area, Judd Brook flows through a broad, approximately 1-mi wide valley and joins the Tenmile River to the south of the study area. Several ponds are present in the study area. At 604 W. Johnson Ave., the lower pond (figs. 2 and 6) is in part natural, but it has been excavated and expanded from its original extent. The upper pond is about $7 \mathrm{ft}$ higher than the lover one and is an artificial impoundment. Geohydrologic units present in the study area include fine-grained glacial stratified deposits, glacial till, and fractured sedimentary bedrock. The geohydrology of the 


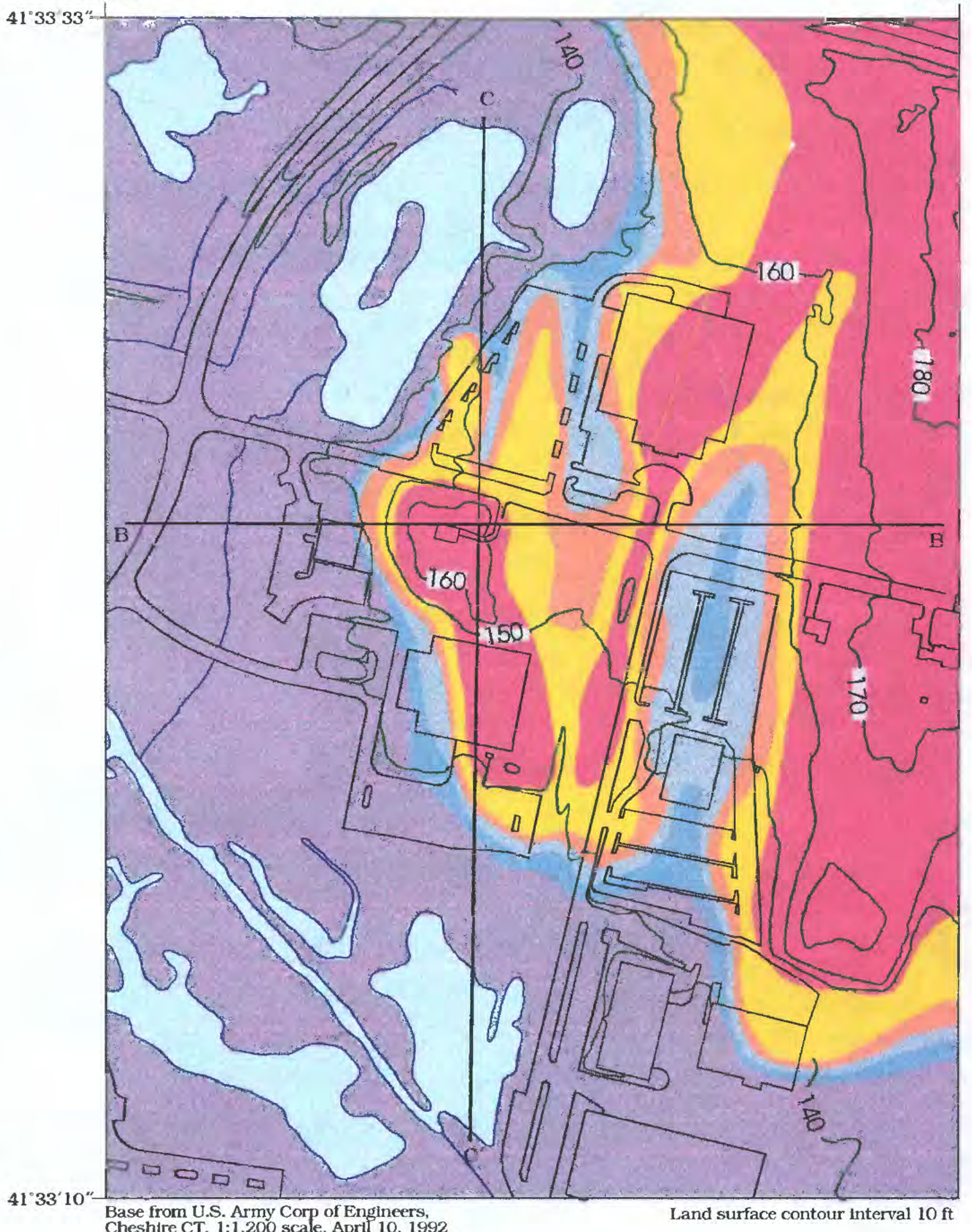

Cheshire CT, 1:1,200 scale, April 10, 1992

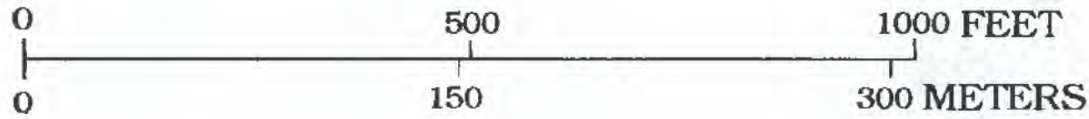

EXPLANATION

Thickness of unconsolidated materlals. In feet
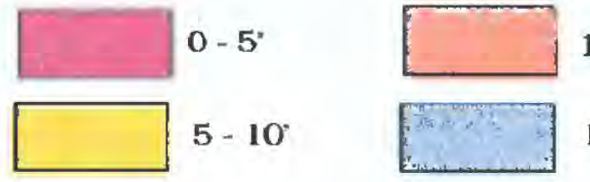

$10-15$

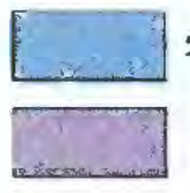

$20-25^{\circ}$

$15-20^{3}$

$>25^{\prime}$

Figure 6. Thickness of unconsolidated materials and location of section lines, B-B', C-C', Cheshire study area, Cheshire, Connecticut. All data points used to construct thickness map located on figure 2. See Appendix 1 for depths to bedrock. 
study area is complex, as a result of the lithologic and hydraulic properties of the unconsolidated materials and the sedimentary bedrock, and the location of recharge and discharge areas.

\section{Geologic Units}

\section{Unconsolidated Materials}

The low hill on which the study area is located is underlain by bedrock and covered by relatively thin unconsolidated glacial materials. Although the published surficial geologic map of the area (LaSala, 1961) shows till as the surface material at $604 \mathrm{~W}$. Johnson Ave., several exposures, as well as logs of well and test borings in the study area, indicate that the surficial material is fine to medium sand, silt, and clay of glaciolacustrine origin. The bedrock hill is below the former water level of glacial Lake Southington, and a thin mantle of fine-grained lacustrine sediments was deposited over the locally till-blanketed bedrock surface to an altitude of at least $170 \mathrm{ft}$. The upper glaciolacustrine sediments are somewhat coarser than the sediments in the lower part of the section; they consist predominantly of thin-layered, fine to medium sand and silt, whereas the lower sediments are principally rhythmically-laminated, thin, alternating layers of silt and clay (varves). Glacial till occurs as a thin surface unit only above an altitude of $170 \mathrm{ft}$ in the eastern part of the study area; glacial till occurs locally in the subsurface beneath glaciolacustrine sediments.

The thickness of unconsolidated material overlying bedrock in the study area is shown in figure 6. The glacial sediments thicken substantially to the west and south in the study area. Geologic sections B-B' and C-C' (figs. 7 and 8) show that most of the areas above an altitude of $140 \mathrm{ft}$ are underlain by a few to about $20 \mathrm{ft}$ of glaciolacustrine fine to medium sand overlying fine sand and silt. Surfaces at or below an altitude of $140 \mathrm{ft}$ are underlain by upper fine sand and silty sand that grades downward to varved silt and clay. Fine-grained stratified deposits beneath the broad Judd Brook and Tenmile River valleys are 25 to $100 \mathrm{ft}$ thick. Locally, in the valley in the western and southern part of the study area, coarse-grained sands and gravels underlie the finegrained silt and clay deposits and are related to ice- marginal deposition associated with glacial meltwater sequences to the south in the Tenmile River valley.

Several wells that tap glacial stratified deposits in the area penetrate silt and clay deposits and are screened in the underlying sand and gravel; examples are well CS-216 (fig. 2) with a reported yield of $400 \mathrm{gal} / \mathrm{min}$ and well A-5, which is screened in $3 \mathrm{ft}$ of gravel beneath $54 \mathrm{ft}$ of silt and clay and has a reported yield of $5 \mathrm{gal} / \mathrm{min}$. The upper sandy sediments in the study area are relatively permeable; however, the thick varved silts and clays beneath the Judd Brook valley have very low permeability and westward ground-water flow in these unconsolidated materials is significantly impeded.

\section{Bedrock}

\section{Lithology}

The study area is underlain by eastward dipping fluvial redbeds of the lower New Haven Arkose. The bedrock section beneath the study area is stratigraphically about $2,000 \mathrm{ft}$ above the base of the formation. The basal unconformity/western border fault, which separates the New Haven Arkose from older crystalline bedrock, is exposed about $1.2 \mathrm{mi}$ west of the study area. Detailed lithology and stratigraphy of a 1,200-ft-long exposure of bedrock along Route 691 at the north edge of the study area (see fig. 2) is described by McInerney (1993). USGS personnel also examined this exposure and made additional measurements of bedding strike and dip as well as orientations of high-angle fractures that cut the beds. Photographs from the Rt. 691 exposure are shown in figure 9. Continuous cores taken at TH-1, TH-2, and TH-3 show lithology and structure similar to that seen in outcrop (see core logs in appendix 2). As seen in the Route 691 exposure (fig. 9) and in cores, the bedrock consists of alternating units of two basic rock types:

(1) Channel sandstone units: gray-brown to pale red-brown medium to coarse sandstone and pebble conglomerate in 6- to 15 -ft-thick sequences, commonly fining upward; locally, channel sequences are stacked; sedimentary structures include planar beds, festoon cross-beds, and planar 


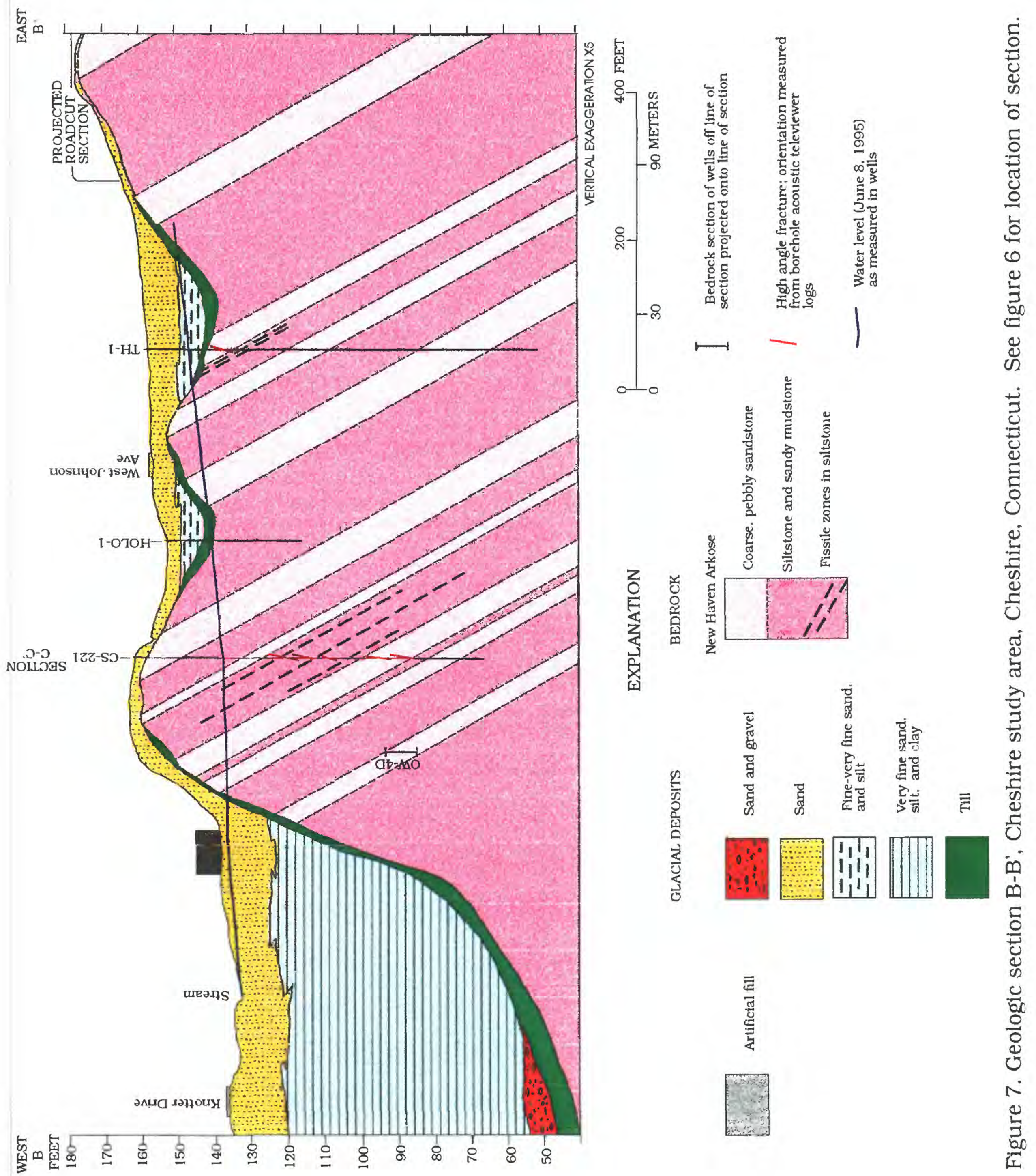




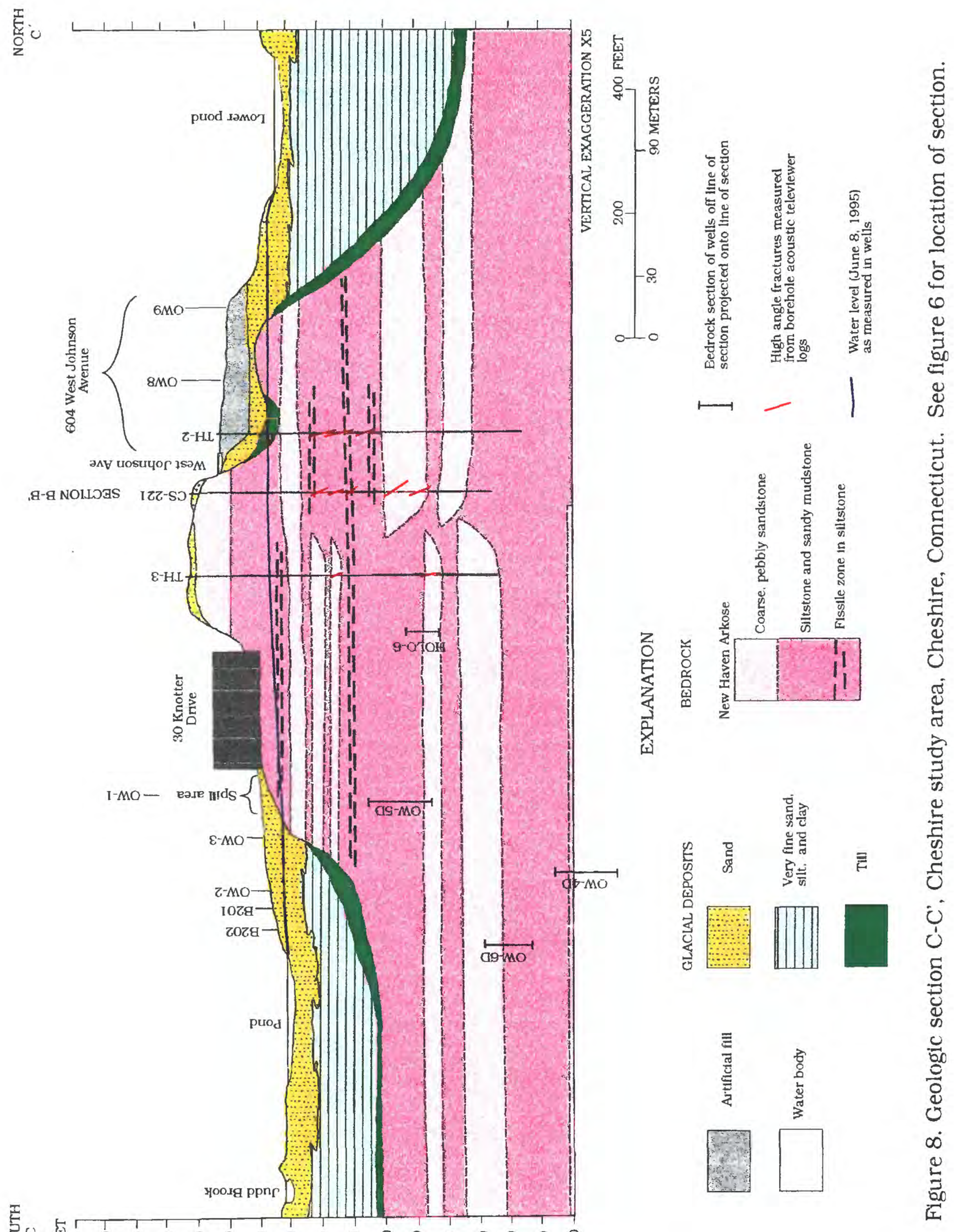


tangential cross-beds; sedimentary structures are commonly obliterated by bioturbation. (These units are the light colored layers seen in fig. 9.)

(2) Overbank mudstone units: red-brown mudstone (sandy siltstone and silty sandstone) with 1- to 3-ft-thick layers of red-brown fine sandstone; in 6- to 50-ft-thick sequences. Some mudstone layers display thin-bedded zones of siltstone that are particularly fissile. (These units are the dark red colored layers seen in fig. 9.)

Irregular, discontinuous, gray calcareous zones of caliche paleosol are common, especially within the mudstone units; these are ancient soil zones where there has been calcification as laminae, breccia, nodules, and vertically elongated nodules. In the most mature caliche zones, the rock is nearly all limestone. Also conspicuous are greenish gray patches within the red mudstone and sandstone where the hematite grain-coating was removed by reducing soil waters. The mineral composition of sandstone of the New Haven Formation has been described in general by Hubert and others (1992). These rocks are lithic arkose containing roughly equal percentages of quartz and feldspar (including quartz-feldspar rock fragments) and lesser amounts of other rock fragments, including quartzite, schist, and phyllite. Petrologic analysis of the Route 691 outcrop by McInerney (1993) indicates that the feldspar grains are dominated by plagioclase and plagioclase-gneiss rock fragments. Other rock fragments are quartzite and subordinate phyllite and schist. Principal cements in the rocks of the New Haven Arkose are albite, which is present as overgrowths on plagioclase grains, and ferroan calcite and calcite (Hubert and others, 1992).

A suite of borehole-geophysical logs was collected from each of the deep bedrock wells. These logs, along with lithologic logs from continuous cores, are included in appendix 2. Sample logs for $\mathrm{TH}-2$ are shown in figure 10. Comparison of the core $\log$ with formation resistivity and naturalgamma logs shows that these geophysical logs are excellent indicators of lithology in these rocks. Channel sandstone units have high electromagnetic-resistivity values (150-325 ohm-m) and relatively low gamma values (75-100 cps). Finergrained mudstone units have lower resistivity and higher gamma counts. In a few places, high gamma peaks occur in the channel sandstone units (see 55-ft depth in TH-2 gamma log, fig. 10); these are most likely related to the local presence of pebbles in the coarse-grained units that contain a high amount of potassium feldspar.

\section{Structure}

In the Rt. 691 outcrop, the average bedding strike is N. $3^{\circ} \mathrm{W}$., and the dip is eastward at about $20^{\circ}$. Projection along strike $900 \mathrm{ft}$ southward shows that layers underlying the hill on the eastern side of 604 W. Johnson Ave. are stratigraphically equivalent to the western half of the Rt. 691 outcrop. Rock units cored at TH-1, TH-2, and TH-3 and those present at CS-221 are stratigraphically 100 to $300 \mathrm{ft}$ below the units exposed along the highway; this relationship can be seen on geologic section B-B' shown in figure 7. Bedrock wells were drilled along the strike of bedding, $100 \mathrm{ft}$ to the north (TH-2) and $130 \mathrm{ft}$ to the south (TH-3) of the pre-existing domestic well (CS-221). Bedrock well TH-1 was drilled $420 \mathrm{ft}$ east of TH-2, TH-3 and CS-221 in the down-dip direction. Geologic section B-B' (fig. 7) is drawn in an east-west direction, through CS-221 and $\mathrm{TH}-1$, and shows the dip of bedding. Geologic section C-C' (fig. 8) is drawn in a north-south direction through TH-2, CS-221, and TH-3, and is along the strike of bedding where bedding planes are horizontal. In order to show unconsolidated materials as well as bedrock, sections B-B' and C-C' were both constructed using $5 \mathrm{X}$ vertical exaggeration. The actual $20^{\circ}$-bedding dip angle appears significantly steepened on section B-B' as a result of the vertical exaggeration. Section B-B' shows that beds penetrated at CS-221 are stratigraphically below those penetrated at $\mathrm{TH}-1$; there is no stratigraphic correlation between these wells. Section C-C' shows that there is good stratigraphic correlation of beds along strike in TH-2, CS-221, and TH-3; however, the lower channel sandstone units are discontinuous between CS-221 and TH-3. A fissile zone within a mudstone unit at an altitude of approximately $110 \mathrm{ft}$ (approximately 50-ft depth in $\mathrm{TH}-3$ and CS-221; approximately 40-ft depth in TH-2) appears to be continuous between all three wells. Another fissile zone, at an altitude of approximately $122 \mathrm{ft}$, is continuous between CS-221 and TH-2. 

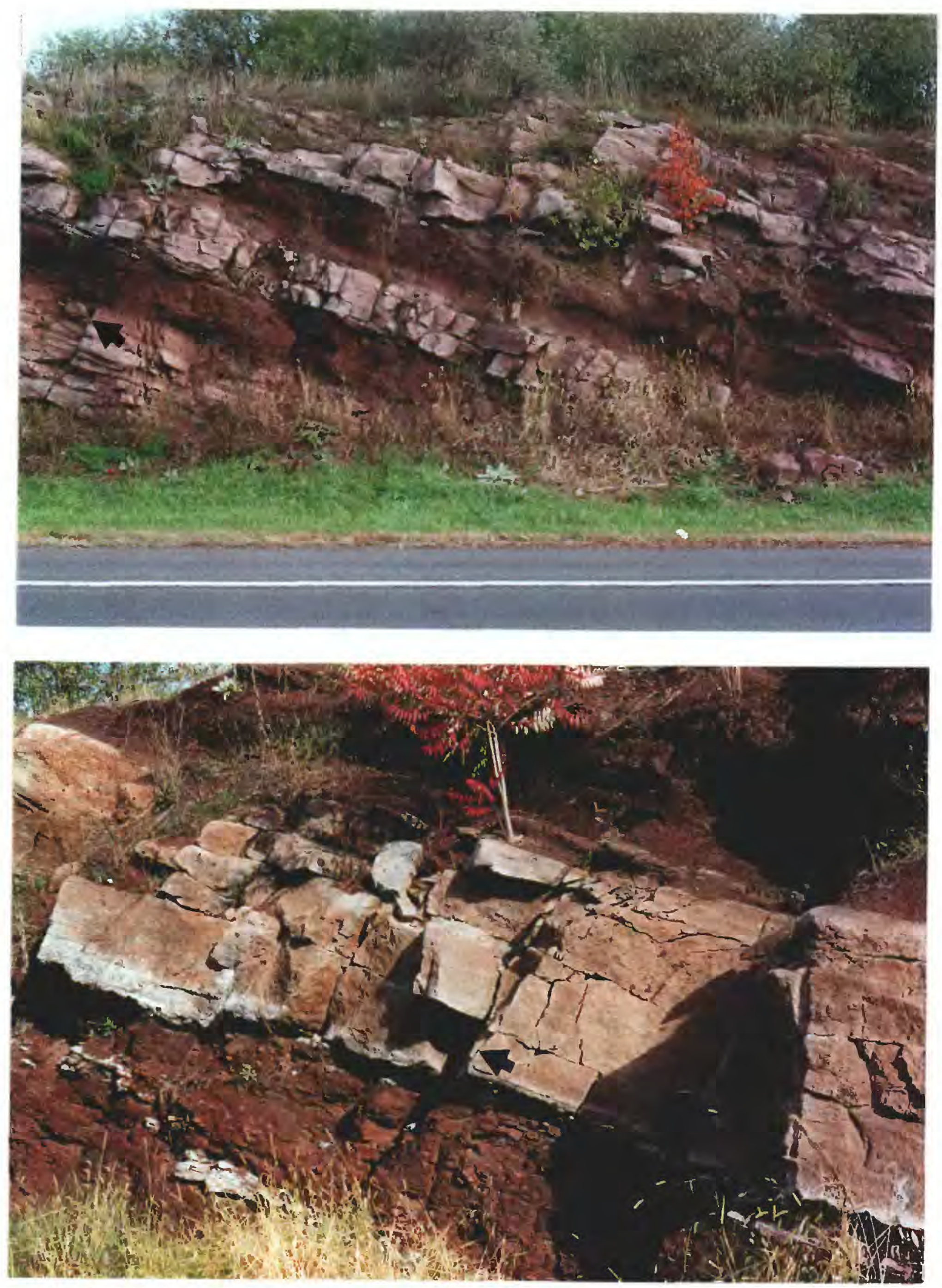

Figure 9. Bedrock outcrop at Rt. 691 roadcut showing east-dipping channel sandstone units (light color) and overbank mudstone units (dark red color).

Upper photo shows about $50 \mathrm{ft}$ of section horizontally and $15 \mathrm{ft}$ of section vertically. Lower photo taken closer to the outcrop has a shovel for scale in lower right; handle is $2 \mathrm{ft}$ long. Some of the small-scale fracturing (seen especially in the lower photo) and some widening of larger fractures are most likely due to blasting for this roadcut. Note the orthogonal relationship of high-angle fractures to bedding and that most high-angle fractures occur in sandstone units; arrows point to the few high-angle fractures that cut mudstone units as well. 
$\begin{array}{ll}\text { Wellname } & \text { TH-2 } \\ \text { Location } & \text { Cheshire } \\ \text { Altitude TOC } & 153.15 \\ \text { Date } & 05 / 04 / 95\end{array}$

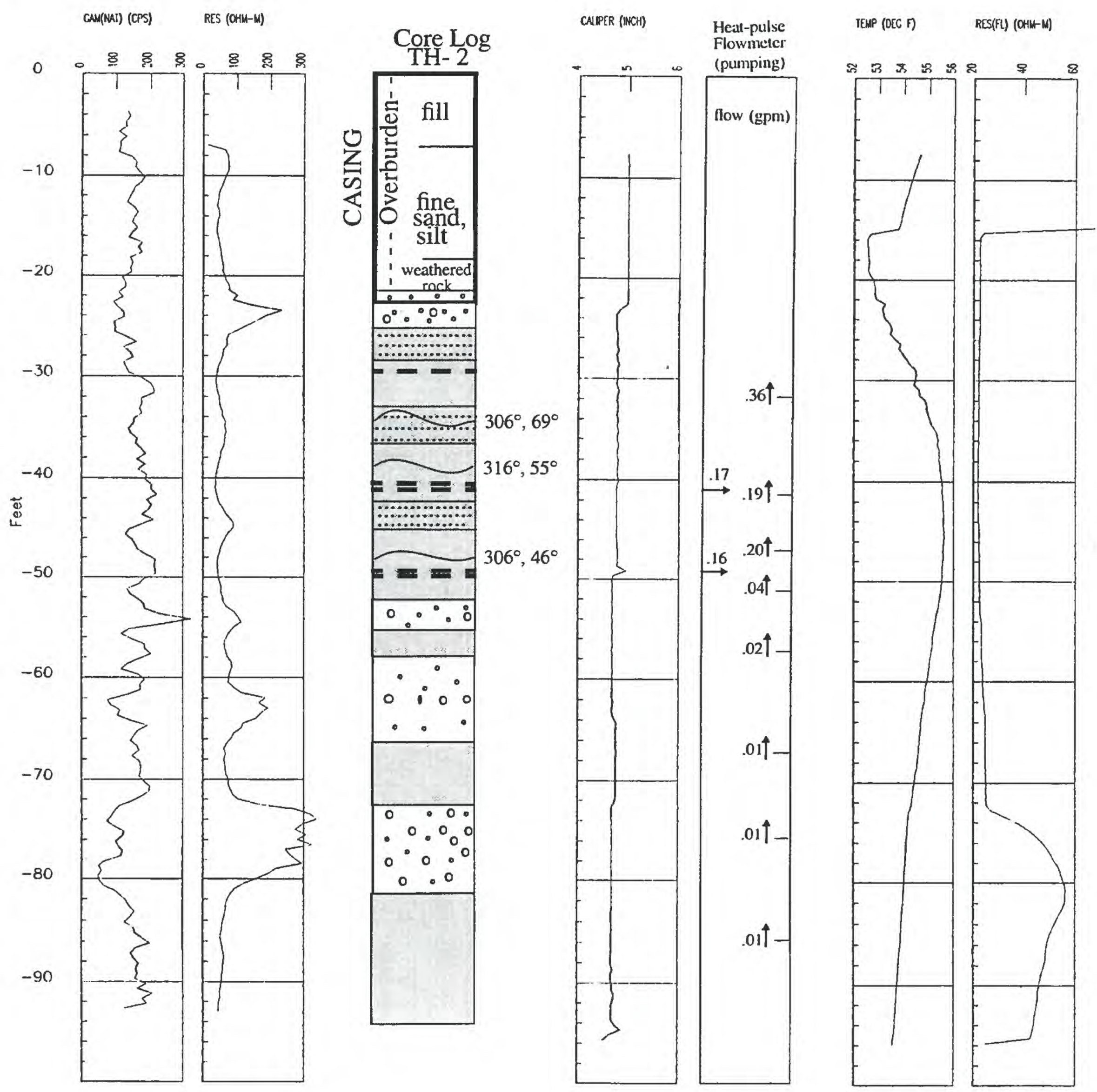

EXPLANATION FOR CORE LOG

\begin{tabular}{|c|c|}
\hline $\begin{array}{lll}0 & 0 & 0 \\
0 & 0 & 0 \\
\end{array}$ & Channel sandstone unit \\
\hline $306^{\circ}, 69^{\circ}$ & $\begin{array}{l}\text { high-angle fracture measured from acoustic televiewer log } \\
\text { numbers are dip azimuth and dip angle }\end{array}$ \\
\hline & $\begin{array}{l}\text { Overbank mudstone unit; dotted zones are fine sandston } \\
\text { heavy dashed lines indicate fissile zone in siltstone unit }\end{array}$ \\
\hline
\end{tabular}

Figure 10. Borehole=geophysical and core logs for TH-2, Cheshire study area, Cheshire, Connecticut. 
As seen in the Route 691 outcrop (fig. 9), the eastward dipping strata are cut by a consistent set of high-angle fractures. These fractures are present mostly in the channel sandstone units, where they are typically spaced 1 to $5 \mathrm{ft}$ apart and are oriented perpendicular to bedding (paleovertical orientation). Measurements of fracture orientations at the Rt. 691 outcrop show that this fracture set has an average strike direction of N. $23^{\circ} \mathrm{E}$. and average dip of $60^{\circ}$ to the WNW. The paleovertical orientation and northeast trend of these fractures indicates that they formed early in the history of the Hartford Basin while it was still subject to the northwestsoutheast extensional stress of rifting. Similar fracture sets have been observed elsewhere in the Hartford Basin (Hubert and others, 1992, fig. 25) and in similar rocks of the Newark Basin in New Jersey (Vecchioli and others, 1969; Morin and others, in press).

Rose diagrams of fracture and bedding strikes from the Rt. 691 outcrop and from borehole acoustic-televiewer logs in the deep bedrock wells are shown in figure 11. Also shown are lower hemisphere stereonet plots of poles to bedding and fracture planes that illustrate the orthogonal relationship between bedding planes and high-angle fractures. The slight difference in average orientations between features measured in outcrop and those measured from borehole logs can be attributed to the likely condition that the boreholes are somewhat deviated from vertical; measurements of dip angle are, therefore, apparent and somewhat less than the true dip.

Caliper, TV camera, and acoustic-televiewer $\operatorname{logs}$, as well as examination of cores, indicate that fissile zones parallel to bedding in the siltstone units are present in a number of places in the deep bedrock wells; these zones produce breakouts in the borehole wall that can be seen on caliper logs. Some breakouts also occur at the base of channel sandstone units. High-angle fractures also produce breakouts in the borehole wall; all locations where the orientation of high-angle fractures could be measured from the acoustic-televiewer $\log$ in the bed- rock wells are shown on figure 10 , in appendix 2 . On sections B-B' and C-C' (figs. 7 and 8), the highangle fractures are shown as red lines at their proper orientation projected onto the line of section. The distances to which these fractures extend beyond the borehole is not known. The orthogonal relationship between high-angle fractures and todding planes is not clear on the geologic sections tecause of the vertical exaggeration of the sections as well as resulting apparent dip due to projection. Heatpulse flowmeter measurements, borehole-fluid conductivity, and temperatures logs indicate that important water-bearing zones in these rocks include some, but not all, fissile zones that are parallel to the bedding plane and some high-angle fractures. The high fluid-resistivity values in the lower part of TH-2 (fig. 10) and TH-1 (appendix 2) are due to high sediment content in the water at these zones.

An azimuthal square-array resistivity survey was conducted in the open field immediately east of CS-221 (see location on fig. 2) to detect the presence and orientation of steeply dipping, saturated openings (fractures or bedding-parallel features) at depth in the bedrock. Composite resistivity values for 3-, 4-, and 6-m (shallow) and 9-, 13-, and 17-m (deep) arrays are shown in figure 12. All except the upper 3-m array show higher resistivity in a WNW/-ESE direction than in other directions. The primary anisotropy in the rock is therefore interpreted to trend in a NNE direction ( $15^{\circ}-30^{\circ}$ azimuth). This direction is consistent with the average st ike of high-angle fractures measured in outcrop and in the bedrock wells (fig. 11). A possible secondary fracture orientation can be interpreted from th e data having an azimuth of $330^{\circ}-345^{\circ}$; the effect of the secondary orientation on the data set is small. indicating a less steeply dipping, less numerous, less open, or less pervasive fracture set. Analysis of the data for the primary fracture set yields an est'mated fracture porosity in the rock of 0.02 with a standard deviation of 0.003 based on a specific condictance of ground water of $500 \mu \mathrm{S} / \mathrm{cm}$ (as measure 1 from borehole fluid-resistivity logs). 


\section{RT. 691 OUTCROP DATA}

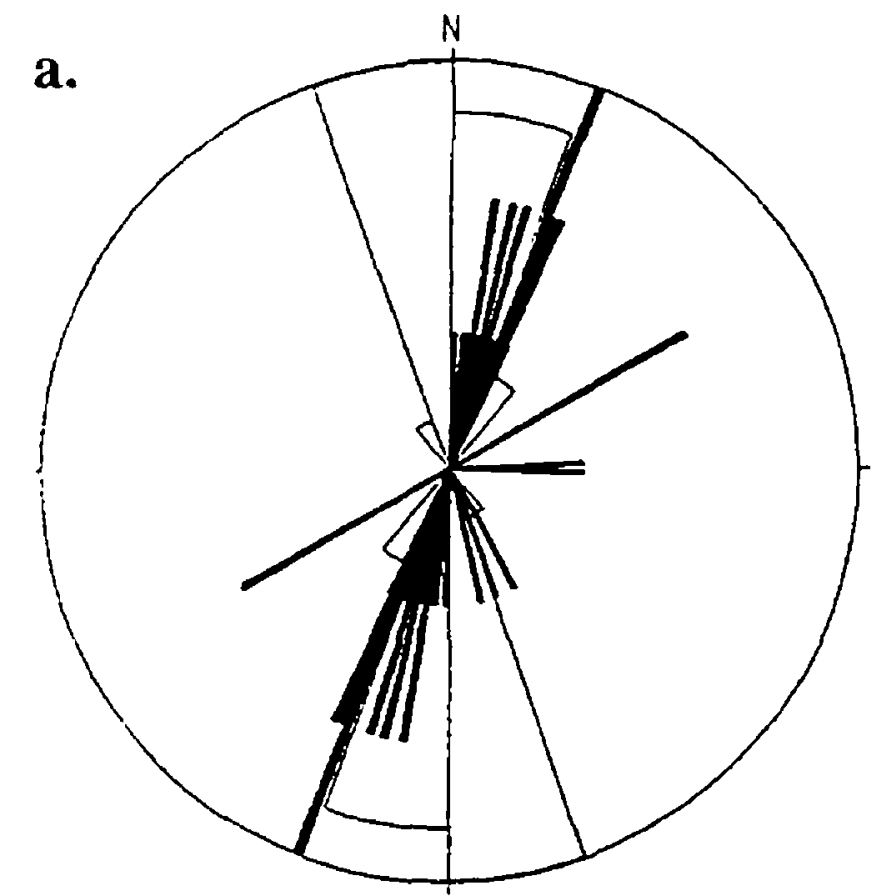

Fracture strike in $1^{\circ}$ classes, $n=32$ (longest ray represents 3 measurements)

Beddiing strike in $20^{\circ}$ classes, $n=18$ (longest ray represents 6 measurements) mean bedding $=358^{\circ}$

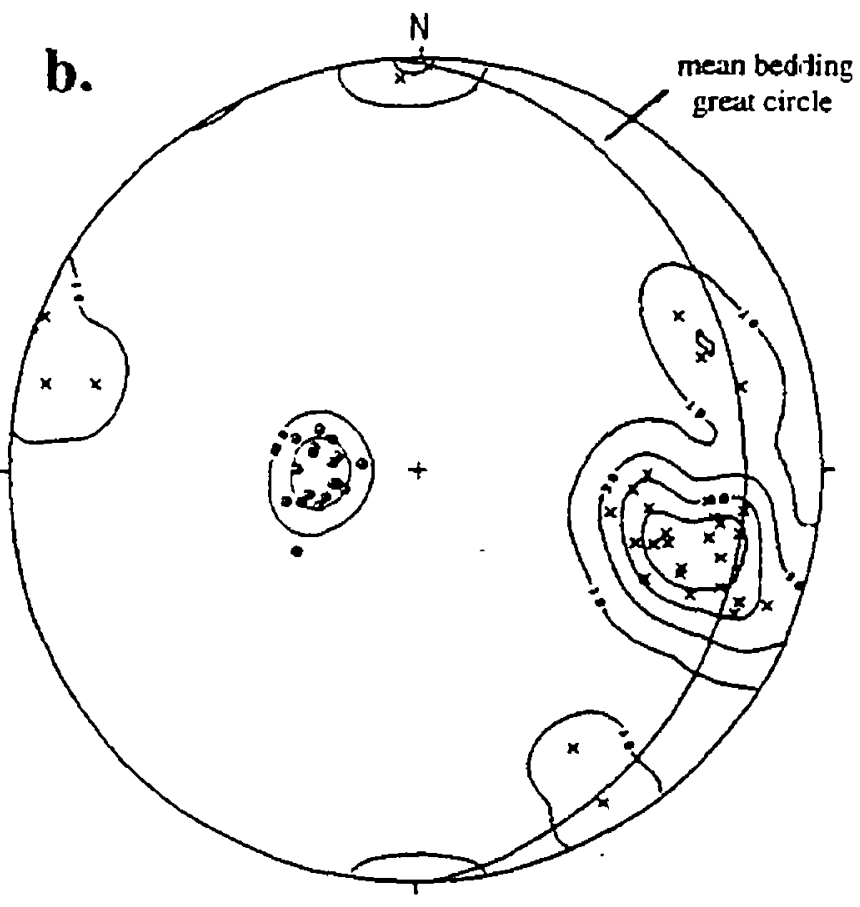

$x$ Poles to fracture planes, $n=32$

- Poles to bedding planes, $n=18$

\section{BOREHOLE ACOUSTIC TELEVIEWER DATA FROM BEDROCK WELLS}

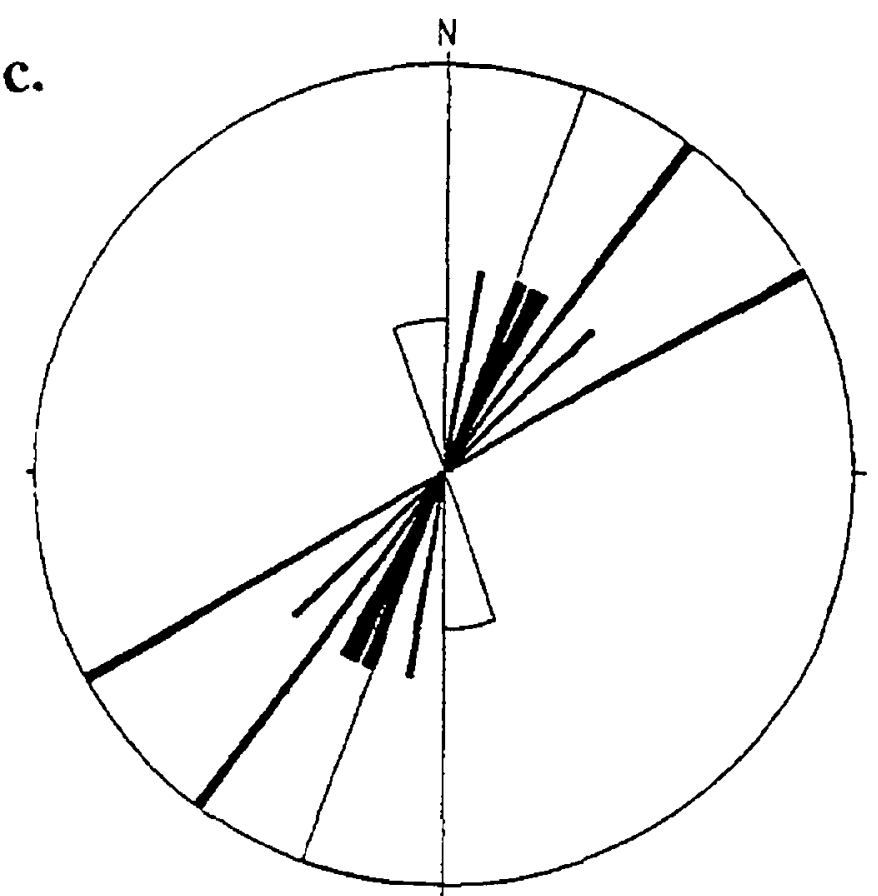

Fracture strike in $1^{\circ}$ classes. $n=12$ (Iongest ray represents 2 measurements)

Beddiing strike in $20^{\circ}$ classes. $n=10$ (longest ray' represents 4 measurements) mean bedding $=358^{\circ}$

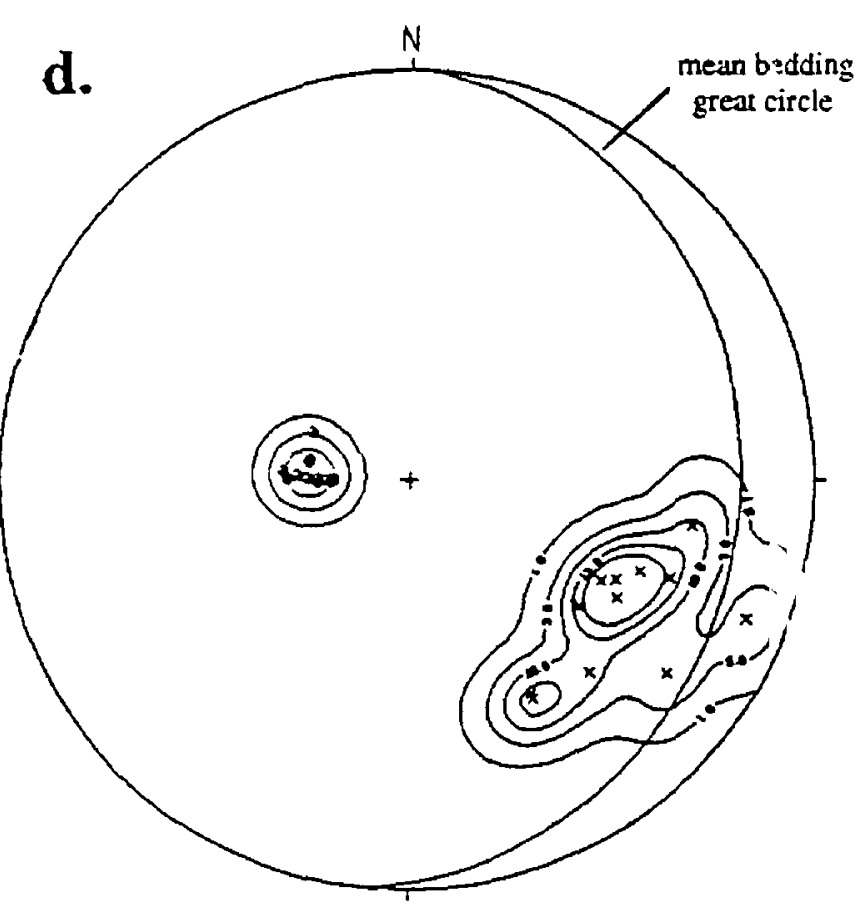

$x$ Poles to fracture planes. $n=12$

- Poles to bedding planes. $n=10$

Figure 11. Rose diagrams showing strike of bedding and fractures $(\mathrm{a}, \mathrm{c})$. Lower hemisphere stereo-net contoured plots of poles to bedding planes and fracture planes (b, d), Cheshire study area, Cheshire, Connecticut. (Note the orthogonal relation between bedding planes and fractures planes in Rt. 691 outcrop data and the borehole acoustic-televiewer data from bedrock wells.) 


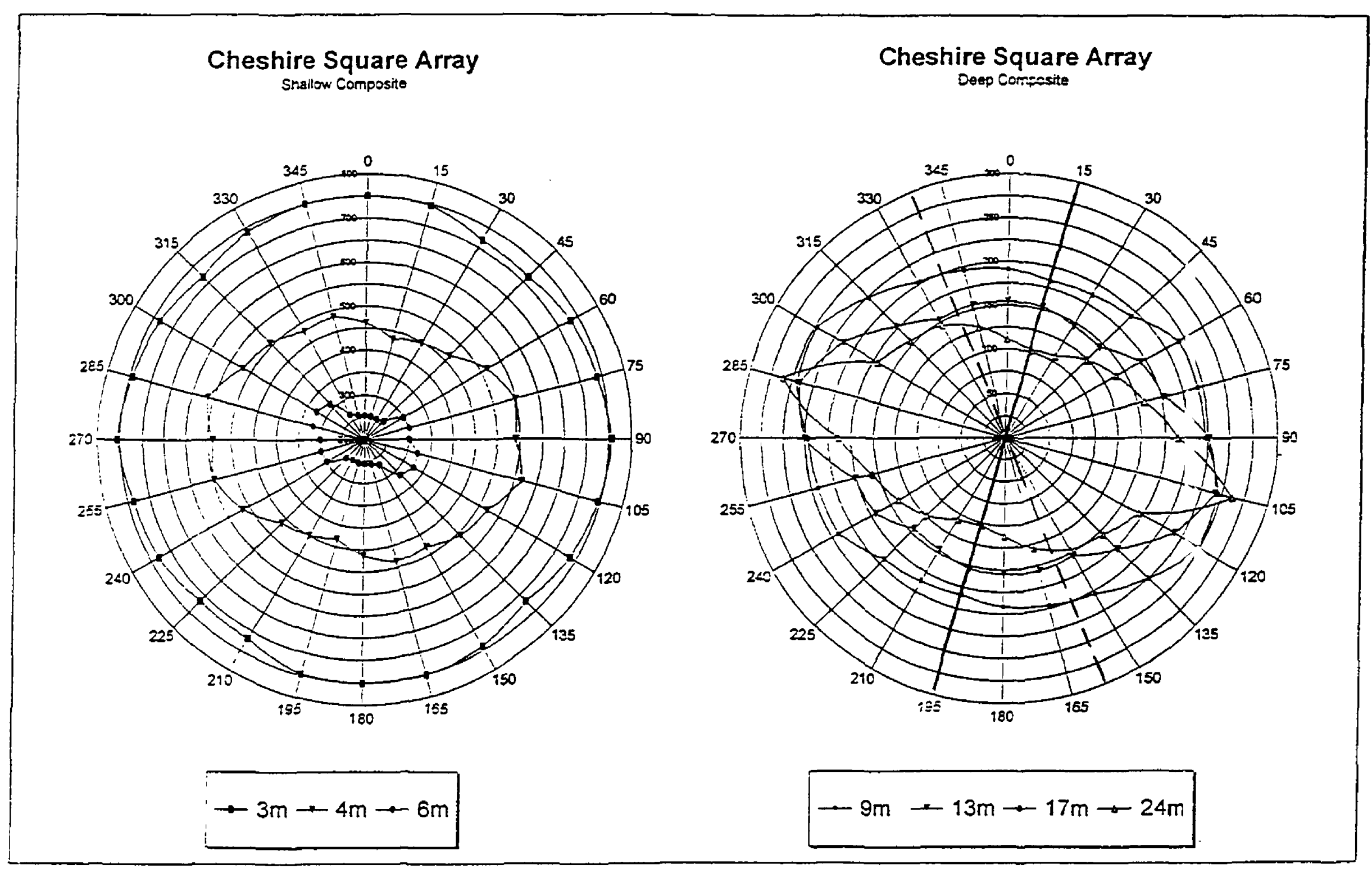

EXPLANATION

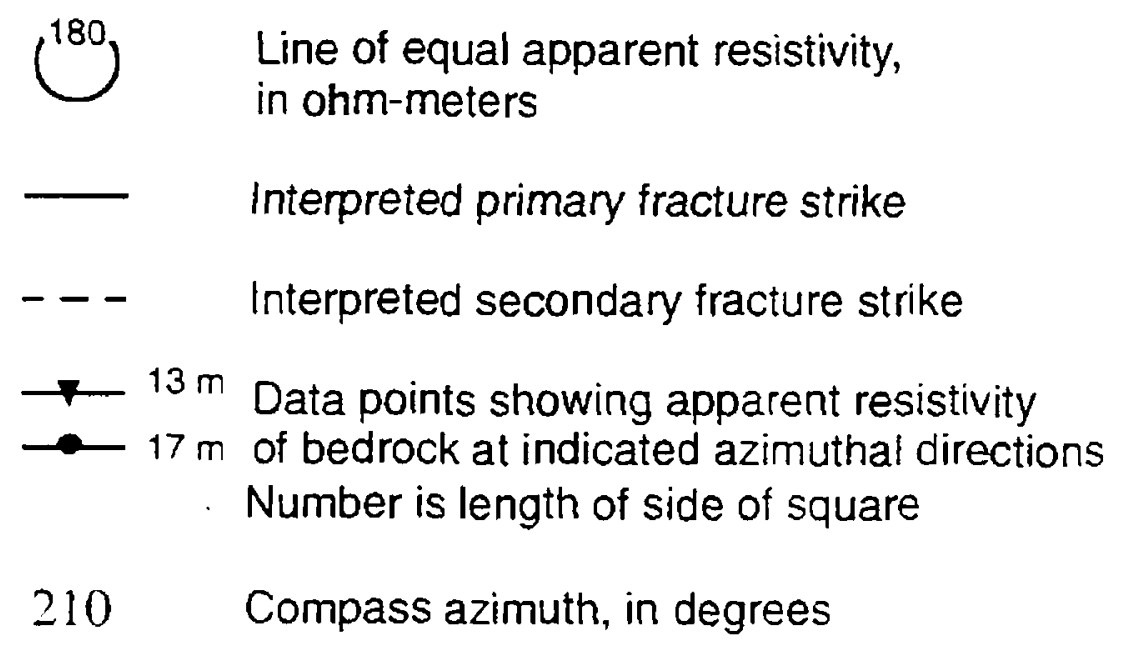

Figure 12. Azimuthal plots of magnitude and direction of resistivity, Cheshire study area, Cheshire, Connecticut. 


\section{Ground-Water-Flow System}

Ground-water and surface-water levels were monitored during the investigation to better understand the ground-water-flow system at the study area, including the interaction between the unconsolidated deposits and underlying fractured bedrock. In addition, hydraulic tests of the fractured bedrock, including four short aquifer tests and borehole heat-pulse flowmeter tests at wells CS-221, $\mathrm{TH}-1, \mathrm{TH}-2$, and $\mathrm{TH}-3$, were done to improve the understanding of the fractured-bedrock flow system.

Measurements of the yield and hydraulic conductivity of glacial deposits in the study area have been reported. Most well yields from unconsolidated (glacial) deposits reported by Ground Water Associates (1980) were $1 \mathrm{gal} / \mathrm{min}$, although one well (A-5), located near the lower pond at $604 \mathrm{~W}$. Johnson Ave., screened in $3 \mathrm{ft}$ of medium gravel at a depth of 54 to $57 \mathrm{ft}$ below land surface, yielded $5 \mathrm{gal} / \mathrm{min}$. These low yields likely result from the low hydraulic conductivities of the fine sand and silt and till deposits in the study area. The low yields might also have been caused by the type of pump used in the test or by well-construction techniques. Hydraulic conductivity of unconsolidated deposits at 30 Knotter Dr. was determined by use of slug tests (ALTA Environmental Corporation, 1994b, p. 7 and Appendix F). At well HOLO-4, which is screened in a silty sand layer, an average hydraulic conductivity of $2.73 \mathrm{ft} / \mathrm{d}$ is reported. Hydraulic conductivity at wells OW-5S, OW-6S, and OW-7, which are screened in a fine to medium sand layer, ranges from 0.37 to $1.58 \mathrm{ft} / \mathrm{d}$.

\section{Water Levels}

Continuous water-level records provide information on the response of the ground-waterflow system to precipitation and on the hydraulic connection between unconsolidated deposits and bedrock. Ground-water levels were monitored at 10 observation wells in the study area during the investigation. The 10 well sites at which water levels were monitored are CS-221, TH-1, SW-1, HOLO 1, A-2, A-5, SW-2, TH-2, TH-3, and OW-4D. Waterlevel records are shown in appendix 3 ; the locations of these 10 well sites are shown on figure 2 . Synoptic measurements of ground-water and pond levels also were made at 29 observation wells and 2 pond stations on June 8, 1995 to determine ground-water levels and flow directions throughout the study area at one point in time.

The longest period of continuous water-level monitoring was at well CS-221 - from late November 1994 through August 1995. This well is cased $14 \mathrm{ft}$ through unconsolidated materials and the upper part of bedrock and is an 82-ft open hole in the bedrock formation. The water-level records from this well and from observation well A-2, which is a 2-in. well screened near the water table in unconsolidated deposits, indicate that groundwater levels in both the unconsolidated deposits and fractured bedrock respond quickly to precipitation (fig. 13 and appendix 3), and that there appears to be good hydraulic connection between the urconsolidated deposits and underlying fractured bedrock. The latter point is evidenced by the corre'ation of water-level fluctuations between the urconsolidated deposits and fractured bedrock.

The largest fluctuation in ground-water levels during the investigation was nearly $12 \mathrm{ft}$ at $\mathrm{TH}-\mathrm{I}$ (appendix 3), which is cased to a depth of $18 \mathrm{ft}$ through the unconsolidated materials and is a $90-\mathrm{ft}$ open hole in bedrock. Smaller fluctuations of about $3 \mathrm{ft}$ took place during the investigation in observation wells screened in unconsolidated deposits. Generally, larger ranges in ground-water-level fluctuations were observed in bedrock wells than in wells screened in the unconsolidated deposits. These larger fluctuations likely result fom the lower storage capacity of the fractured bedrock than that of the unconsolidated deposits.

The synoptic measurement of grourd-water levels on June 8, 1995 was used to determine the distribution of ground-water levels and to better understand ground-water flow directions. As seen in the continuous water-level records (fig. 13; appendix 3), June 1995 was a period of relatively low ground-water levels in the study area. In fact, ground-water levels were below normal in June 1995 for this part of Connecticut (B.S. Davies, U.S. Geological Survey, written commun., 1995). Twenty-nine ground-water levels were measured at 22 sites; in addition, surface-water levels in the upper and lower ponds at $604 \mathrm{~W}$. Johnson Ave. were measured (see table 2 ). Of these 31 waterlevel measurements, 22 were used to construct a map of the water-table altitude on June 8, 1995 (fig. 14.) 


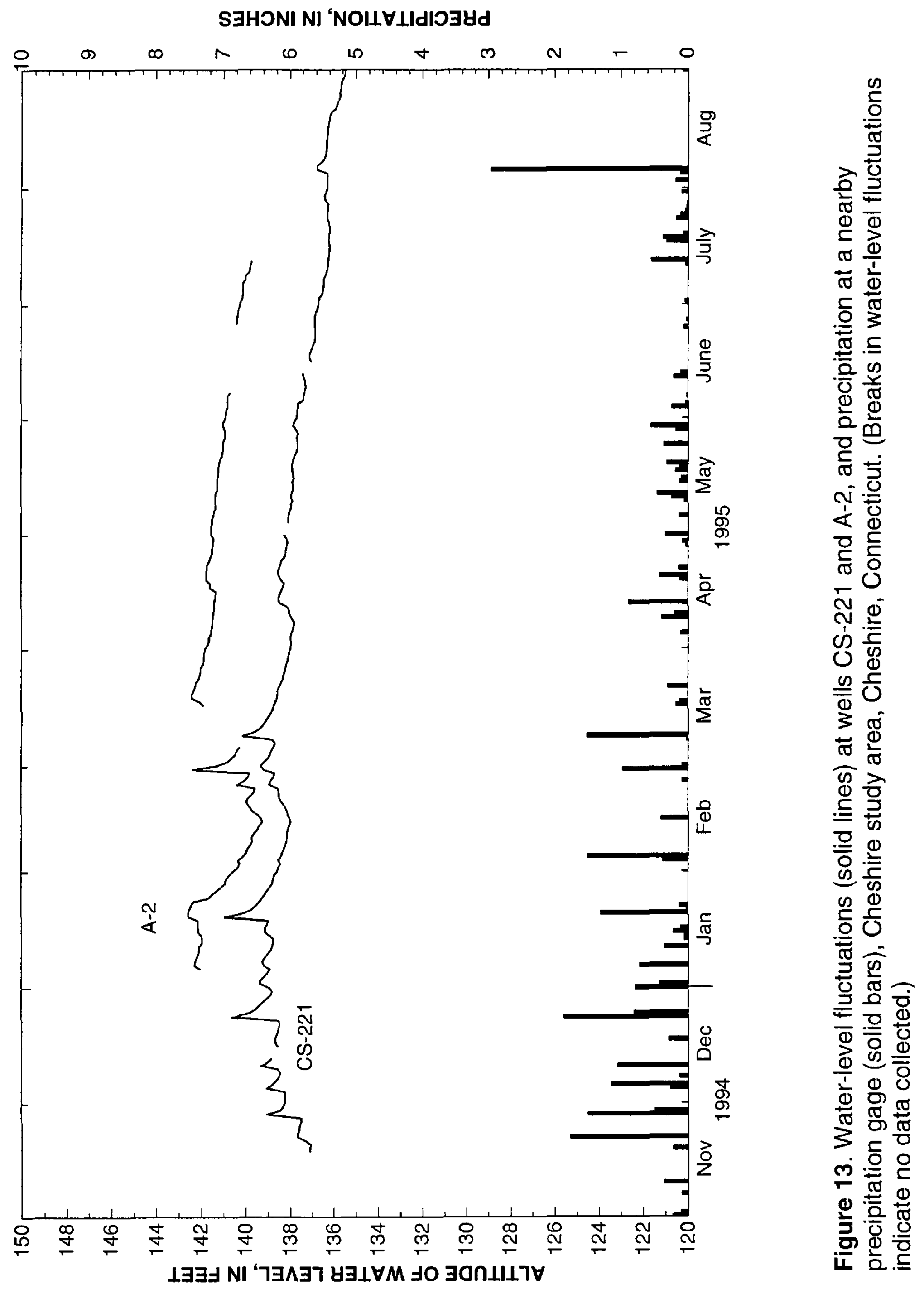


Table 2. Ground-water and pond-level measurements in the Cheshire study area on June 8, 1995

[USGS, U.S. Geological Survey; MP, measurement point; Altitudes to sea level datum; PVC, top of polyvinyl chloride casing; BR, bedrock, UC, unconsolidated deposits. Sources of data for unit and screened interval: 1. this investigation; 2. John Sima drilling company; 3. Ground Water Associates, 1980; 4. HRP Associates, 1987; 5. Haley and Aldrich, 1993; 6. ALTA Environmental,1994b; 7. ALTA Environmental, Fax to J. Dolan, U.S. Environmental Protection Agency, 5/23/95]

\begin{tabular}{|c|c|c|c|c|c|c|c|}
\hline $\begin{array}{c}\text { Well } \\
\text { number }\end{array}$ & MP & $\begin{array}{l}\text { Depth to } \\
\text { water, } \\
\text { in feet }\end{array}$ & $\begin{array}{c}\text { Altitude of } \\
\text { MP, } \\
\text { in feet }\end{array}$ & $\begin{array}{l}\text { Altitude of } \\
\text { water, } \\
\text { in feet }\end{array}$ & $\begin{array}{c}\text { Screened } \\
\text { unit }\end{array}$ & $\begin{array}{l}\text { Altitude of } \\
\text { screened } \\
\text { interval, } \\
\text { in feet }\end{array}$ & $\begin{array}{l}\text { Source of } \\
\text { data for } \\
\text { unit and } \\
\text { screened } \\
\text { interval }\end{array}$ \\
\hline HOLO-1 & Platform & 12.30 & 152.46 & 140.16 & BR & 138 to 118 & 4 \\
\hline HOLO-6 & PVC & 8.05 & 144.57 & 136.52 & $\mathrm{UC}$ & 138 to 118 & 5 \\
\hline HOLO-5 & PVC & 4.01 & 140.69 & 136.68 & UC & 134 to 114 & 5 \\
\hline OW-8 & PVC & 9.16 & 141.07 & 131.91 & $\mathrm{UC}$ & 137 to 120 & 5 \\
\hline OW-9S & PVC & 7.08 & 138.47 & 131.39 & $\mathrm{UC}$ & 136 to 126 & 6 \\
\hline OW-9I & PVC & 4.64 & 138.47 & 133.83 & UC & 90 to 80 & 6 \\
\hline OW-10S & PVC & 4.46 & 135.77 & 131.31 & $\mathrm{UC}$ & 133 to 123 & 6 \\
\hline OW-10I & PVC & 2.25 & 134.50 & 132.25 & $\mathrm{UC}$ & 96 to 86 & 6 \\
\hline OW-4S & PVC & 8.23 & 140.00 & 131.77 & UC & 135 to 120 & 5 \\
\hline OW-4I & PVC & 6.48 & 138.78 & 132.30 & $\mathrm{UC}$ & 110 to 100 & 6 \\
\hline$O W-4 D$ & PVC & 6.45 & 138.77 & 132.32 & BR & 95 to 85 & 7 \\
\hline OW-7 & PVC & 8.76 & 141.72 & 132.96 & UC & 126 to 116 & 5 \\
\hline OW-5S & PVC & 7.26 & 140.10 & 132.84 & $\mathrm{UC}$ & 132 to 122 & 5 \\
\hline OW-5D & PVC & 9.34 & 141.95 & 132.61 & BR & 114 to 104 & 7 \\
\hline OW-3 & PVC & 6.20 & 139.14 & 132.94 & UC & 136 to 122 & 5 \\
\hline OW-2 & PVC & 8.16 & 140.10 & 131.94 & $\mathrm{UC}$ & 135 to 120 & 5 \\
\hline HOLO-4 & PVC & 3.19 & 134.66 & 131.47 & UC & 134 to 119 & 4 \\
\hline OW-6S & PVC & 2.58 & 134.79 & 132.21 & $\mathrm{UC}$ & 109 to 99 & 5 \\
\hline OW-6D & PVC & 3.19 & 135.44 & 132.25 & BR & 96 to 86 & 7 \\
\hline HOLO-3 & PVC & 4.49 & 136.05 & 131.56 & $\mathrm{UC}$ & 135 to 116 & 4 \\
\hline HOLO-2 & PVC & 4.20 & 136.97 & 132.77 & $\mathrm{UC}$ & 130 to 110 & 4 \\
\hline $\mathrm{TH}-1$ & Platform & 12.46 & 158.85 & 146.39 & BR & 140 to 50 & 1 \\
\hline SW-1 & Platform & 12.30 & 158.70 & 146.40 & $\mathrm{UC}$ & 153 to 143 & 1 \\
\hline SW-2 & Platform & 15.85 & 155.00 & 139.15 & UC & 142 to 132 & 1 \\
\hline A-2 & Platform & 6.66 & 147.35 & 140.69 & $\mathrm{UC}$ & 131 to 126 & 3 \\
\hline A-5 & Platform & 2.60 & 140.33 & 137.73 & $\mathrm{UC}$ & 84 to $\varepsilon 1$ & 3 \\
\hline $\mathrm{TH}-2$ & Platform & 15.58 & 153.15 & 137.57 & $\mathrm{BR}$ & 130 to 56 & 1 \\
\hline CS-221 & Platform & 24.90 & 162.17 & 137.27 & $\mathrm{BR}$ & 138 to 66 & 1.2 \\
\hline $\mathrm{TH}-3$ & Platform & 25.75 & 162.80 & 137.05 & $\mathrm{BR}$ & 155 to 6.5 & 1 \\
\hline Upper pond & Bolt on tree & & & 142.34 & & & \\
\hline Lower pond & A-5 & & & 134.98 & & & \\
\hline
\end{tabular}




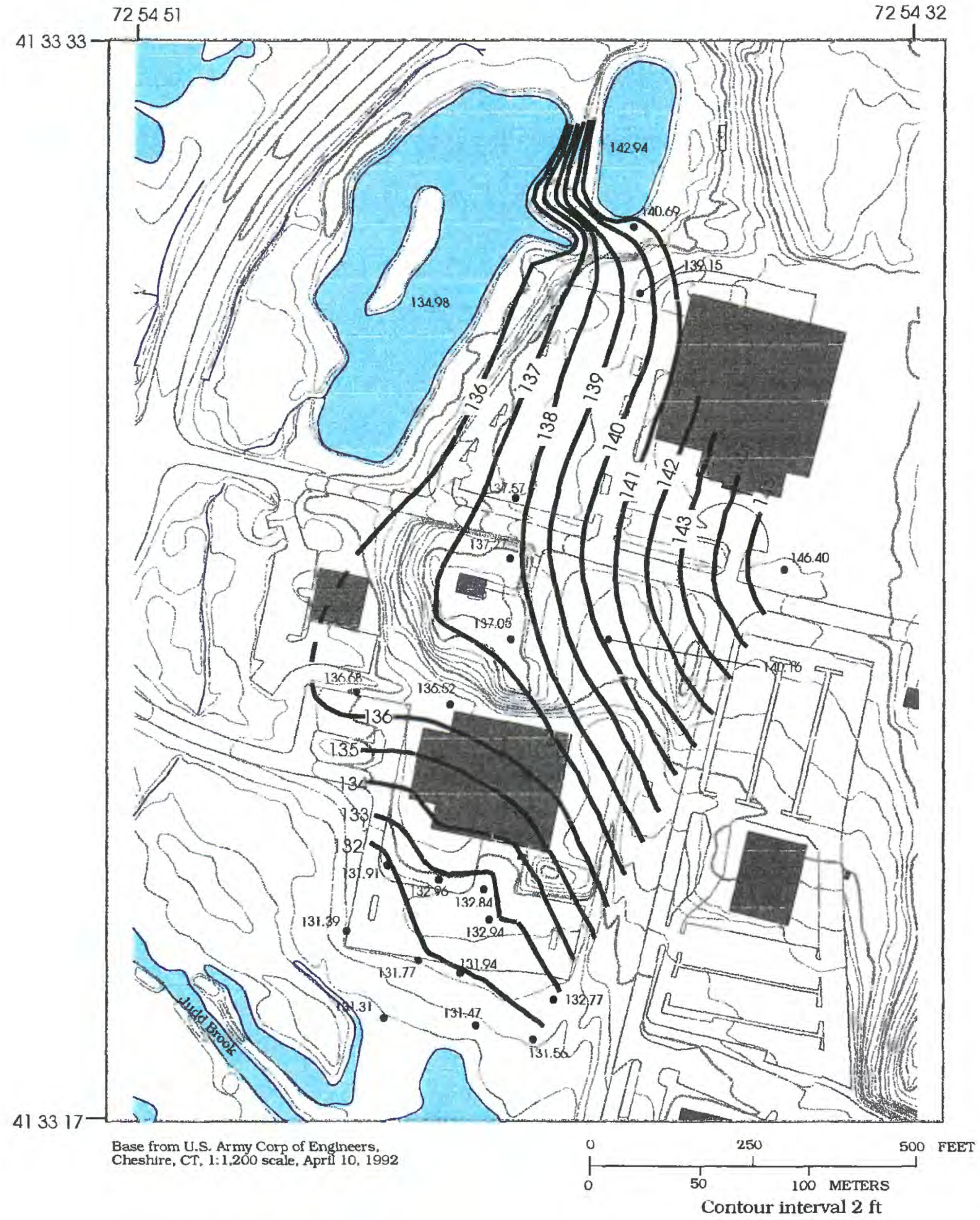

EXPLANATION

131.31 - WELL OR TESTHOLE -- Number is altitude of the water table in feet above sea level

- $136-\quad$ - WATER-TABLE CONTOUR - Altitude of water table in feet above sea level. Dashed where approximate. Contour interval $1 \mathrm{ft}$

Figure 14. Altitude of water table on June 8, 1995, Cheshire study area, Cheshire, Connecticut. 
These 22 measurements include 16 from observation wells screened in unconsolidated deposits at or within $10 \mathrm{ft}$ of the water table; 1 from observation well HOLO-1, open to $20 \mathrm{ft}$ of bedrock; 3 from wells CS-221, TH-2, and TH-3, open to 80 to $90 \mathrm{ft}$ of bedrock; and the 2 pond measurements. The four measurements made in bedrock wells were used with the assumption that vertical hydraulic gradients at these sites are small; this assumption is supported by the heat-pulse flowmeter data, which indicated that vertical-flow components in the wells were very small under ambient ground-water conditions. The map of water-table altitudes (fig. 14) indicates that the predominant ground-water flow direction is from the low bedrock hill on the eastern side of the study area to the west toward the lower pond at $604 \mathrm{~W}$. Johnson Ave. and southwest toward Judd Brook or the wetlands along Judd Brook. The lower pond receives ground-water discharge on its eastern side and is presumed to lose water to the surrounding aquifer on its western side. It is assumed that the upper pond also is connected hydraulically to the aquifer and receives ground-water discharges on its eastern side and loses water on its western side; however, the upper pond may be perched or poorly connected to the aquifer. The lower pond also is drained during parts of the year by an intermittent stream on its western side. During periods of low water levels, such as on June 8 , there is no direct outflow from the pond to the stream; however, the streambed was either moist or had standing water in it during all site visits, which indicates that the water table is not far below the streambed.
At the time of the synoptic ground-waterlevel measurements, the recharge area for ground water that flows past CS-221 was to the east-northeast. The water-table map also indicates a decrease in the hydraulic gradient of the water table downgradient from CS-221. This decreased hydraulic gradient may reflect an increase in the transmissivity of the aquifer in this area.

Ground-water-level measurements made near the lower pond and at several wells provide information on the vertical direction of ground-water flow in the study area. The ground-water level at well A-5 indicates that there is upward groundwater flow toward the lower pond, which is presumed to be a discharge area of the ground-waterflow system. Water levels in this well were above land surface during the time that it was monitored from December 1994 through July 1995 (appendix 3 ). There is also upward ground-water flow within the unconsolidated sediments and from the bedrock to the unconsolidated sediments at the southernmost wells (OW-9, OW-4, OW-6, and OW-10) (table 2). These upward gradients likely cause ground-water discharge into Judd Brook, the marshy area adjacent to Judd Brook, and the small pond at the southern end of property at $30 \mathrm{Knotter} \mathrm{Dr}$. This conclusion is supported by the results of a ground-water-flow model of the regional area (described later in this report). The model indicates that, at the regional scale, streams form hydrologic divides that separate the stream basins into hydrologically independent flow systems. 
Response of the Fractured-Bedrock Aquifer to Hydraulic Stresses

Four aquifer tests were done during the investigation to characterize the response of the fractured-bedrock aquifer to hydraulic stress. These tests were done to (1) improve an understanding of the hydraulic connections among fractures near CS-221, (2) estimate hydraulic properties of the bedrock aquifer near CS-221, and (3) improve an understanding of the hydraulics of this well. Only three of the four tests are reported here. One test was done on December 16, 1994, and two tests were done on June 15 and 16, 1995. During the test on June 16, measurements of borehole flow were made in TH-2 and TH-3 using a heat-pulse flowmeter. The test not reported here was done in May 1995 to aid in the design of the two tests done in June 1995.
The first test was done at CS-221 on Lecember 16,1994 to determine the relation between pumping rates and drawdowns at the well and to estimate the hydraulic properties of the bedrock aquifer at the well site. Three pumping rate: were used during the test: $2 \mathrm{gal} / \mathrm{min}$ for the first $50 \mathrm{~min}$ utes, $4 \mathrm{gal} / \mathrm{min}$ for the next 90 minutes and $6 \mathrm{gal} / \mathrm{min}$ for the final 60 minutes. Water-level recovery was measured in the well for 57 minutes following the cessation of pumping. The static water level at the well site was $23.5 \mathrm{ft}$ below top of casing. Drawdown and recovery of water levels at CS-221 during the aquifer test are shown on figure 15. Although water levels were also measured at well HOLO-1 and TH-1, no observable draw Jowns took place at these sites during the test.

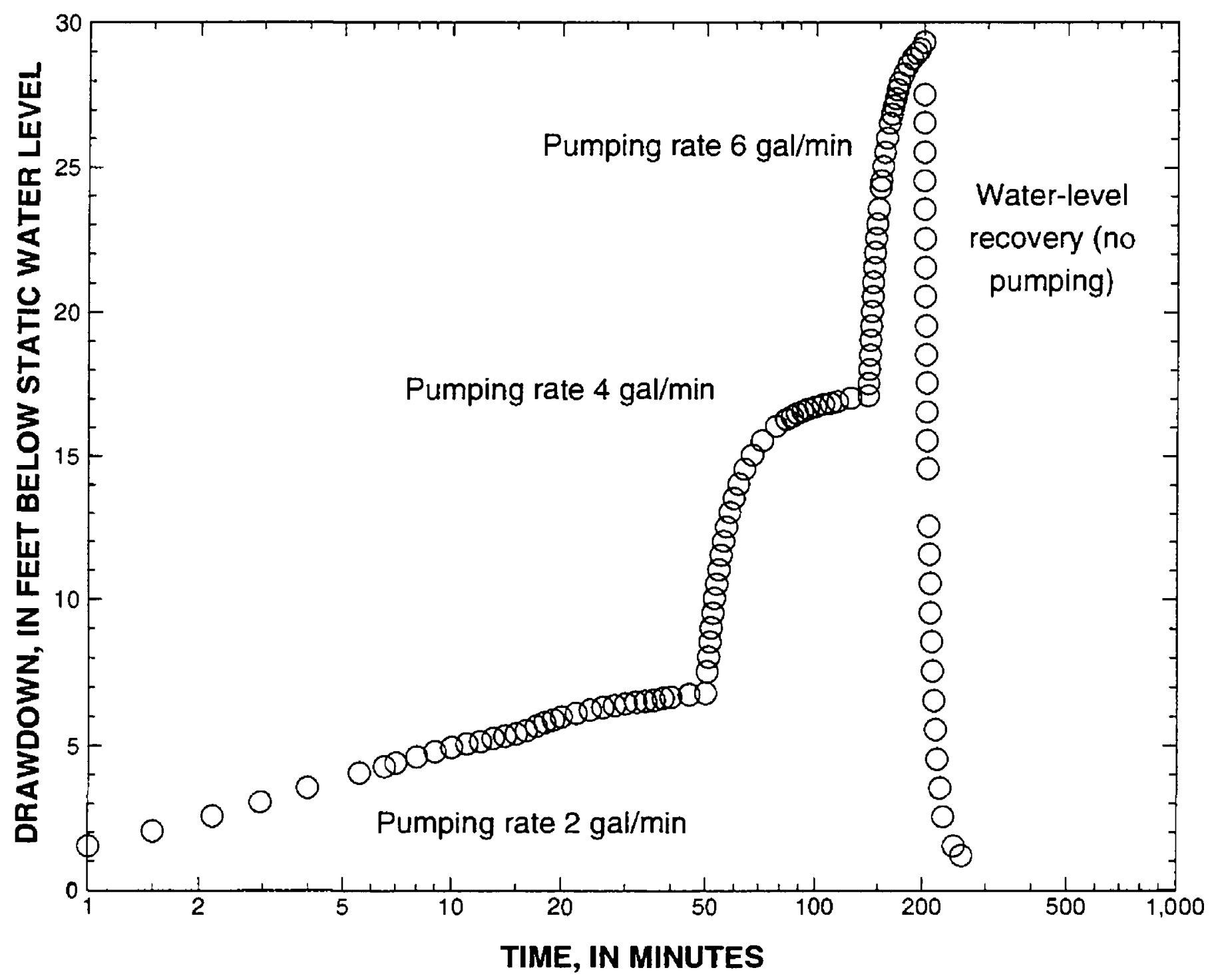

Figure 15. Drawdown of water level at CS-221 during aquifer test on December 16, 1994. [gal/min, gallons per minute] 
The maximum drawdowns measured at CS-221 during the aquifer test were $6.8 \mathrm{ft}$ for a pumping rate of $2 \mathrm{gal} / \mathrm{min}$ (after 50 minutes total pumping time), $17.1 \mathrm{ft}$ for a pumping rate of $4 \mathrm{gal} / \mathrm{min}$ (after 140 minutes total pumping time), and $29.3 \mathrm{ft}$ for a pumping rate of $6 \mathrm{gal} / \mathrm{min}$ (after 200 minutes total pumping time) (fig. 15). The specific capacity of CS-221 was calculated for each of the three pumping rates. Specific capacity of a well is its yield per unit of drawdown after a given time of pumping has elapsed (Driscoll, 1986). Pumping from a well in an unconfined flow system decreases specific capacity as the pumping rate increases, because the saturated thickness of the aquifer in the vicinity of the well is reduced by dewatering of the aquifer. Specific capacity of CS-221 was calculated at the end of each of the three pumping periods when drawdowns were maximum during the respective pumping periods. The specific capacities calculated for the well were $0.29(\mathrm{gal} / \mathrm{min}) / \mathrm{ft}$ when pumping at $2 \mathrm{gal} / \mathrm{min} ; 0.23(\mathrm{gal} / \mathrm{min}) / \mathrm{ft}$ when pumping at $4 \mathrm{gal} / \mathrm{min}$; and $0.20(\mathrm{gal} / \mathrm{min}) / \mathrm{ft}$ when pumping at $6 \mathrm{gal} / \mathrm{min}$.

Water levels recovered quickly after the pump was turned off; water levels recovered to within $1.19 \mathrm{ft}$ of static conditions after 57 minutes of recovery (fig. 15). Wellbore storage can significantly affect the drawdown response at a pumped well shortly after pumping begins. The water pumped from CS-221 shortly after each of the increases in pumping rate likely has two sources: (1) water pumped from storage within the wellbore and (2) water from the aquifer. If all water had come from storage within the wellbore, the rate of drawdown in the well for a pumping rate of $2 \mathrm{gal} / \mathrm{min}$ (for the $0.5-\mathrm{ft}$ wellbore) would have been $1.36 \mathrm{ft} / \mathrm{min}$. The actual observed rate of drawdown was only $0.49 \mathrm{ft} / \mathrm{min}$ during the first 10 minutes of pumping, indicating that most water pumped at the well originated from water released from the aquifer.

Ground-water samples were collected at CS-221 during the aquifer test on December 16 . Seven samples were collected from the pump discharge over the 3-hour duration of the test and were analyzed on site using a portable gas chromatograph with a photoionization detector (S. Clifford, USEPA, written commun., 1994). All samples were found to contain 1.1 DCE in a range of 0.60 to $0.96 \mu \mathrm{g} / \mathrm{L}$ and toluene in a range of 0.83 to $4.70 \mu \mathrm{g} / \mathrm{L}$. One sample collected during the middle of the test was analyzed at USEPA Region 1 laboratory using gas chromatography/mass spectroscopy that showed concentrations of $0.40 \mu \mathrm{g} / \mathrm{L}$ for both 1,1,1 TCA and 1,1 DCA.

Aquifer tests were conducted in the study area on June 15 and 16, 1994. CS-221 was pumped at $2 \mathrm{gal} / \mathrm{min}$ for 200 minutes on June 15 and at $4 \mathrm{gal} / \mathrm{min}$ for 270 minutes on June 16 . Wa er levels were measured at several observation wells prior to, during, and after the tests (figs. 16 and 17). The only wells at which drawdown caused by pumping could be clearly identified were CS-221, TH-2, and TH-3 (shown on fig. 16). Water levels at ot er wells showed little to no response to the short intervals of pumping, with the possible exception of FOLO-5, which is screened in unconsolidated deposits (fig. 17). The drawdown at wells CS-221, T.I-2, and TH-3 during the test of June 16 (pumping rate of $4 \mathrm{gal} / \mathrm{min}$ ) was nearly double that for the test of June 15 (pumping rate of $2 \mathrm{gal} / \mathrm{min}$ ), which indicates that there was a nearly linear resporse to the increase in pumping rates from the first to the second test.

Transmissivity, storage coefficient, and horizontal hydraulic conductivity of the bedrock aquifer near CS-221 were estimated using drawdown data from the two tests. The drawdown data were analyzed using two methods: the Theis curve-matching method and the Jacob semilogarithmic method, which is based on an approximation to the Theis method (Kruseman and de Ridder, 1991, p. 61-67, 223-225). Two assumptions were required in the application of the two methods to the analysis of the drawdown data. First, and perhaps most importantly, it was assumed that the bedrock aq"ifer can be represented by a porous medium. Borehole-geophysical logging done as part of the investigation indicates that ground water does not flow evenly through the aquifer, as it would in a porous medium. Instead, flow is through discrete zones occupied by high-angle fractures or fissile beds. These zones are sufficiently fractured that they are individually equivalent to a porous medium. Second, it was assumed that the change in saturated thick ness due to pumping was sufficiently small relative to the total saturated thickness so that equations that apply strictly to confined aquifers (in which the saturated thickness does not change) could be used. 


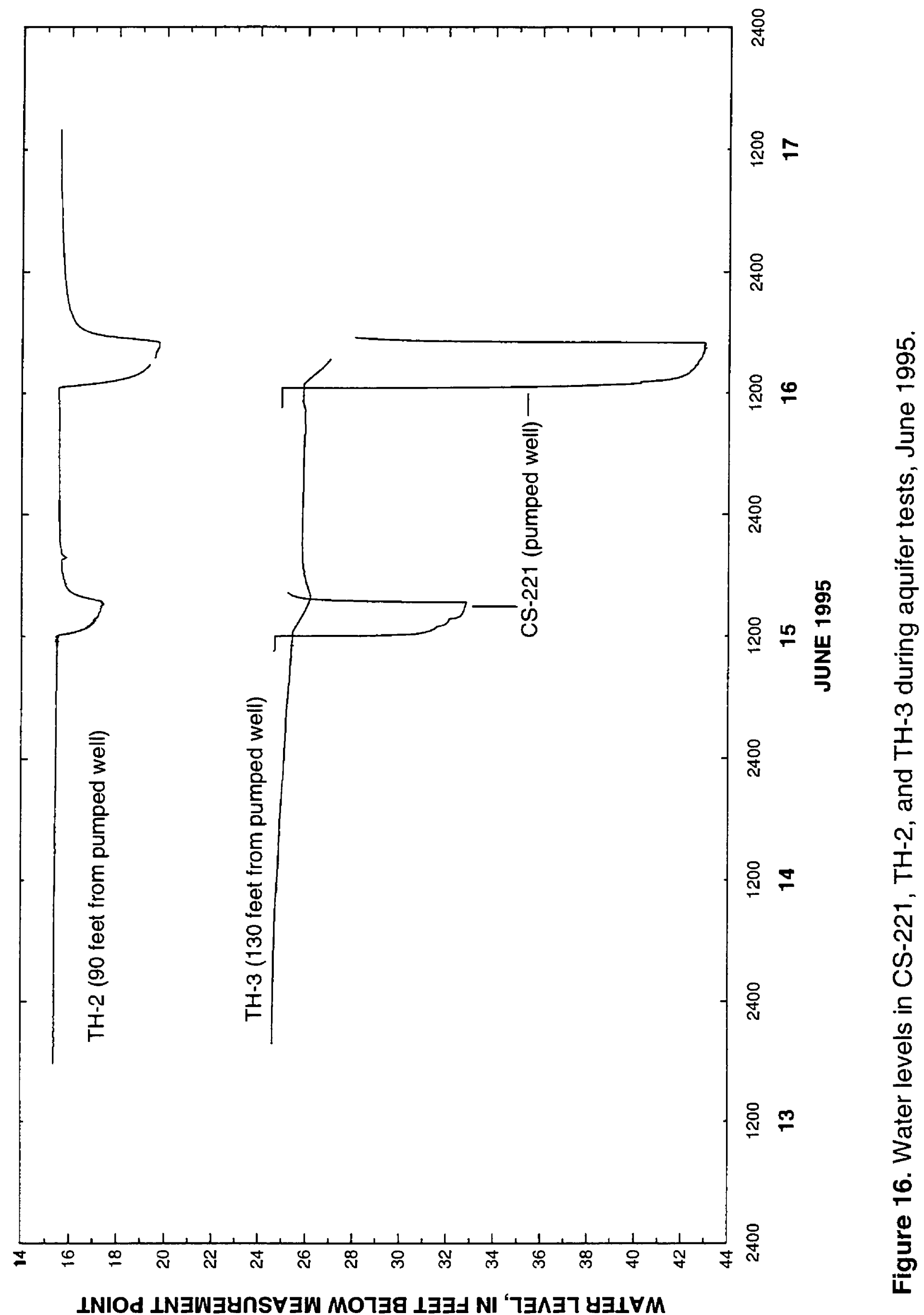



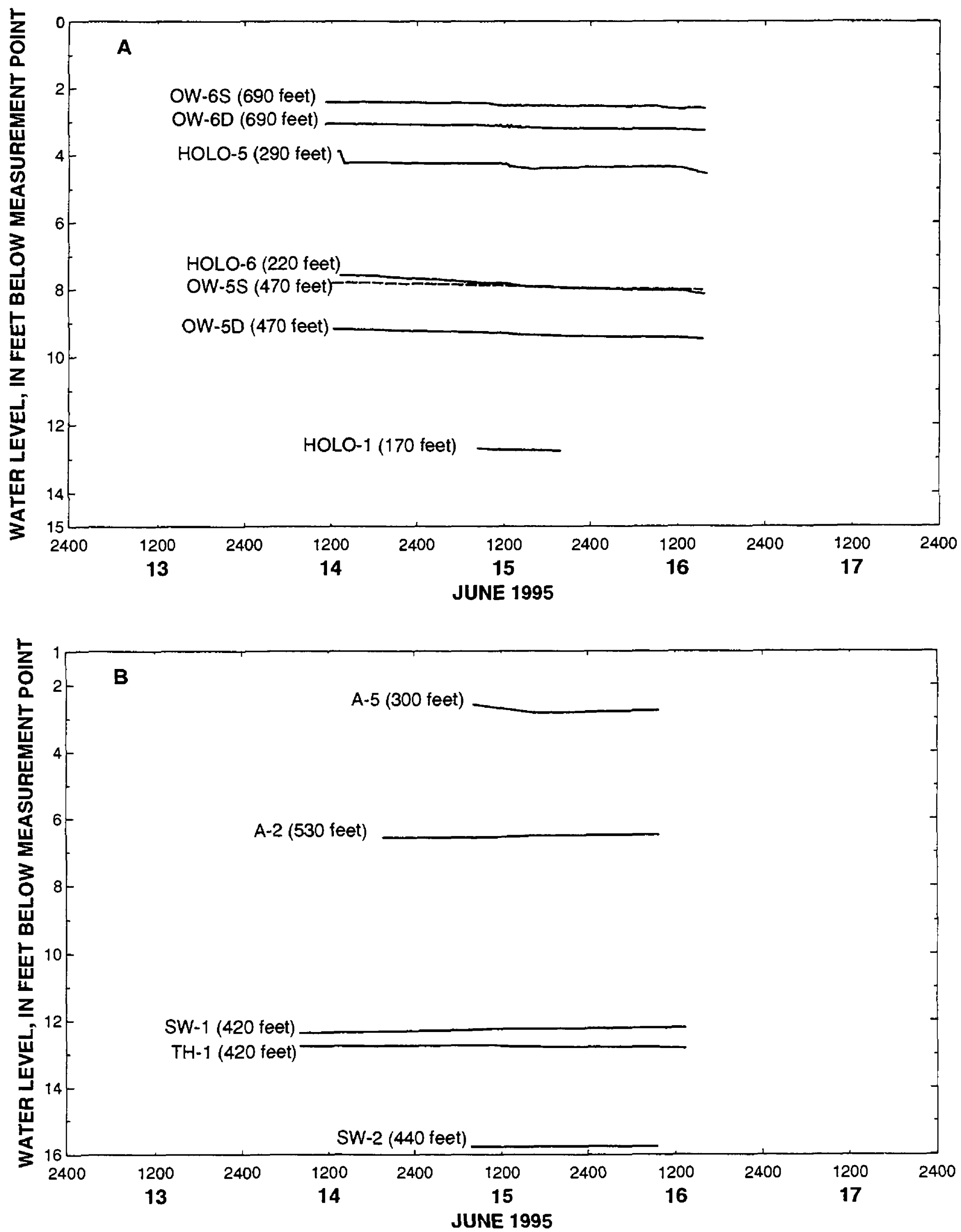

Figure 17 (A and B). Water levels in selected observation wells during aquifer tests, June 1995. [Number is distance from pumped well.] 
The Theis curve-matching method requires that the time-drawdown data be plotted on logarithmic axes. The data are then matched to a type curve (the Theis curve) that is widely available in textbooks on ground-water hydrology and a match point is determined from the overlay of the two graphs (Kruseman and de Ridder, 1991, p. 61-64). Four data values are determined from the match point: first, values of time $\left(t^{*}\right)$ and drawdown $\left(s^{*}\right)$ are read from the graph of time-drawdown data; second, values of the dimensionless coefficients $u$ and $W(u)$ are read from the type curve. The four data values are then used to determine transmissivity $(T)$ and storage coefficient $(S)$ of the aquifer from the following two equations:

$$
\begin{gathered}
T=\frac{Q}{4 \pi s^{*}} W(u) \\
S=4 T t^{*} \frac{u}{r^{2}},
\end{gathered}
$$

where $T=$ transmissivity of the aquifer, in feet squared per minute;

$Q \quad$ = pumping rate of the well, in cubic feet per minute;

$W(u)=$ a dimensionless parameter at the match point;

$$
\begin{aligned}
& \pi=3.14, \text { dimensionless; } \\
& s^{*}=\text { drawdown at the match point, in } \\
& \text { feet; } \\
& S=\text { storage coefficient of the aquifer, } \\
& \text { dimensionless; } \\
& t^{*}=\text { time at the match point, in mirntes; } \\
& u=\mathbf{a} \text { dimensionless parameter at the } \\
& \text { match point; and } \\
& r \quad=\text { radial distance of the observat:on } \\
& \text { well from the pumped well } \\
& \text { (CS-221), in feet. }
\end{aligned}
$$

The portion of the Theis curve that matches

\begin{tabular}{|c|c|c|c|c|c|c|c|}
\hline Well & $\begin{array}{c}\text { Radial } \\
\text { distance to } \\
\text { well } \\
\text { in feet }\end{array}$ & $\begin{array}{c}\text { Dimension } \\
\text {-less } \\
\text { coefficient } \\
u \text { at match } \\
\text { point }\end{array}$ & $\begin{array}{c}\text { Dimension } \\
\text {-less } \\
\text { coefficient } \\
W(u) \text { at } \\
\text { match } \\
\text { point }\end{array}$ & $\begin{array}{l}\text { Transmis- } \\
\text { sivity, } \\
\text { in feet } \\
\text { squared } \\
\text { per day }\end{array}$ & $\begin{array}{c}\text { Storage } \\
\text { coefficient, } \\
\text { dimension- } \\
\text { less }\end{array}$ & $\begin{array}{c}\text { Saturated } \\
\text { thickness } \\
\text { at } \\
\text { beginning } \\
\text { of test, } \\
\text { in feet }\end{array}$ & $\begin{array}{c}\text { Horizental } \\
\text { hydraulic } \\
\text { condu ntiv- } \\
\text { ity } \\
\text { in feet per } \\
\text { da. }\end{array}$ \\
\hline \multicolumn{8}{|c|}{ Test of June 15} \\
\hline $\mathrm{TH}-2$ & 90 & 0.02 & 0.10 & 30 & $1.0 \times 10^{-4}$ & 76.5 & 0.39 \\
\hline $\mathrm{TH}-3$ & 130 & .13 & .12 & 37 & $4.0 \times 10^{-4}$ & 70.5 & .52 \\
\hline \multicolumn{8}{|c|}{ Test of June 16} \\
\hline TH-2 & 90 & .02 & .045 & 27 & $9.4 \times 10^{-5}$ & 76.5 & .35 \\
\hline TH-3 & 130 & .13 & .065 & 40 & $4.3 \times 10^{-4}$ & 70.0 & .57 \\
\hline
\end{tabular}
each of the data curves is shown on figure 18 . Results of the Theis analysis for TH-2 and TH- 3 are summarized in table 3 . Values of $t^{*}=500$ minutes and $s^{*}=0.1 \mathrm{ft}$ were used in each of the four curve matches. Horizontal hydraulic conductivity of the bedrock aquifer was determined by dividing the calculated transmissivity by the saturated thickness of the aquifer at each well. A lower bound on the horizontal hydraulic conductivity was determined by using a saturated thickness at each well eaual to that at the beginning of each test.

Table 3. Results of Theis analyses for aquifer tests on June 15-16, 1995 

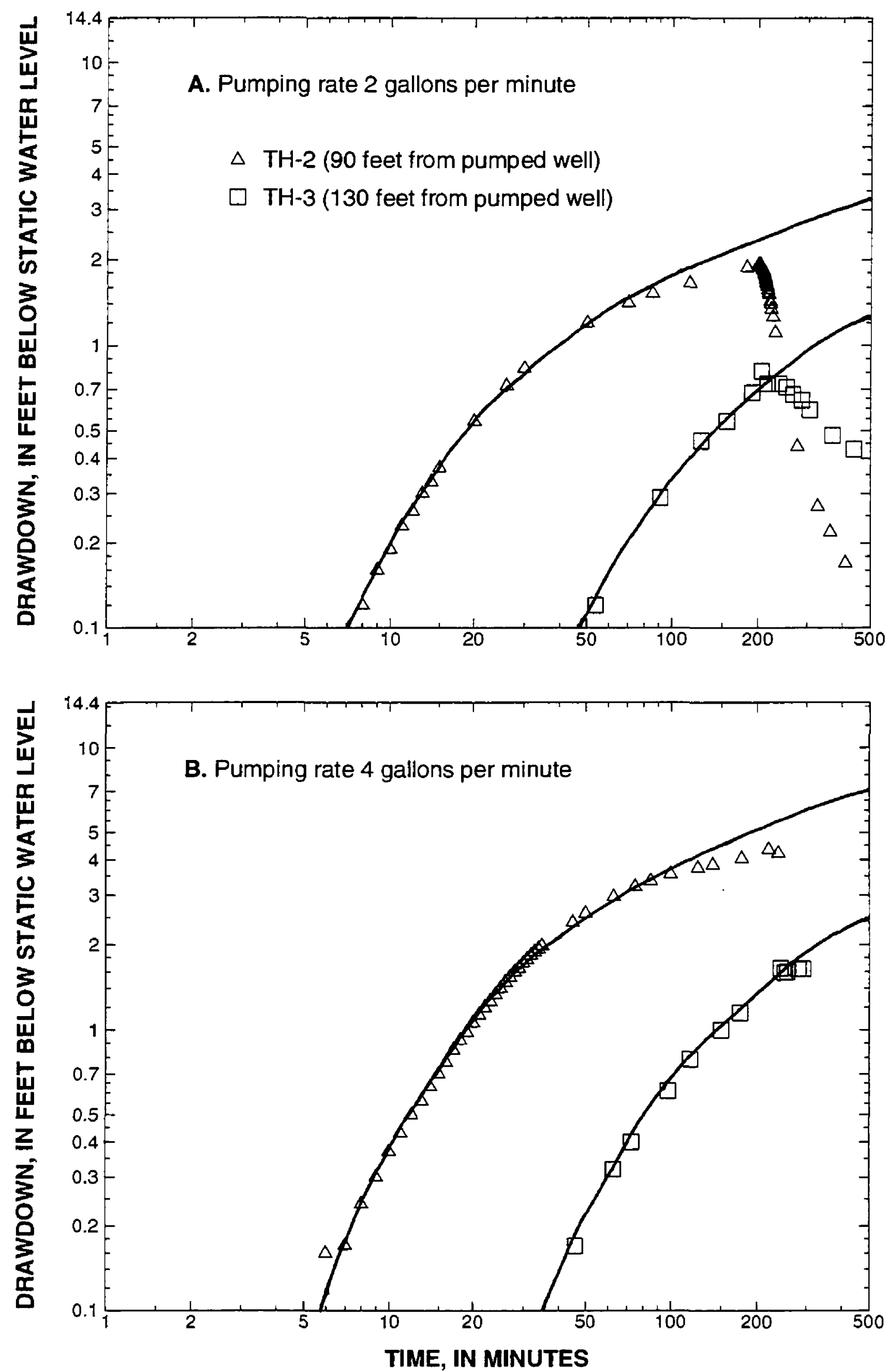

Figure 18. Drawdown of water level at $\mathrm{TH}-2$, and $\mathrm{TH}-3$ during aquifer tests $\mathrm{cf}$ June 15 (A) and June 16, 1995 (B). Solid lines are Theis curves (see text). 
The Jacob semilogarithmic method consists of plotting drawdown data against the logarithm of time and finding a period of time during which the data points follow an approximately straight line. As seen on figure 19, data for wells CS-221 and TH-2 follow approximately straight lines during parts of each test. For the test of June 15, drawdown data at CS-221 and $\mathrm{TH}-2$ follow approximately straight lines from about 10 minutes after the start of pumping until the end of pumping at $200 \mathrm{~min}$ (fig. 19A). Drawdown data at TH-3 also appear to follow a straight line after about 90 minutes of pumping (fig. 19A). For the test of June 16, drawdown data at CS-221 and TH-2 follow approximately straight lines after about 20 minutes of pumping and those at $\mathrm{TH}-3$ after about 100 minutes of pumping. After about 150 minutes of pumping, the rate of drawdown at CS-221 and TH-2 appears to decrease. This decrease in the rate of drawdown, which is similar to the response of a leaky-confined or unconfined aquifer, may be the result of leakage from the unconsolidated deposits that overlie and bound the bedrock or from fractures within the bedrock aquifer that are beyond the immediate connection between CS-221 and TH-2 and TH-3.

The period of the tests during which the data follow approximately straight lines are used in the analysis of transmissivity, storage coefficient, and horizontal hydraulic conductivity. Transmissivity and storage coefficient of the aquifer are calculated from (Kruseman and de Ridder, 1991, p. 66):

$$
\begin{gathered}
T=2.30 \frac{Q}{4 \pi \Delta s} \\
S=\frac{2.25 T t_{o}}{r^{2}},
\end{gathered}
$$

where $\Delta s=$ drawdown on the semilogarithmic plot for one logarithmic cycle of time, in feet (fig. 19); and

to $=$ time at which the straight lines intersect the time- (or $\mathrm{x}$-) axis on figures $19 \mathrm{~A}$ and $19 \mathrm{~B}$, in minutes.
The Jacob semilogarithmic method is a mathematical approximation to the Theis equation that is valid only after a sufficient period of pumping has elapsed and is dependent on several factors, such as the distance to the observation well. The criteria that were used to determine a length of time that was sufficient for each test were based on tho e provided by Kruseman and de Ridder (1991, p. 67 and 223). These criteria are often used in the anal' sis of aquifer-test results. For observation well TH-2, the time criterion used was (Kruseman and de Fidder, 1991, p. 65):

$$
t_{\text {min }}>\frac{r^{2} S}{4 T u}
$$
where $t_{\text {min }}=$ time (in minutes) beyond which the Jacob semilogarithmic analysis is valid, and
$u=0.1$.

Kruseman and de Ridder (1991, p. 67) state that the error between use of the semilogarithmic analysis and that of the Theis equation for a value of $u$ of 0.1 is less than 5 percent. For the pumper well itself, CS-221, the time criterion (based on $c$ more stringent value of $u=0.01$ ) used was (Kruseman and de Ridder, 1991, p. 223):

$$
t_{\min }>\frac{25\left(r_{c}\right)^{2}}{T}
$$

where $\quad r c=$ radius of the unscreened part of the well where the water level is changing (about $0.25 \mathrm{ft}$ for CS-221).

Results of the four analyses from CS-221 and TH-2 are shown in table 4 . Although analyse: were attempted for the results at $\mathrm{TH}-3$ for both aquifer tests, the pumping period did not meet the crit ria of equation 5 and are not reported. Horizontal hydraulic conductivity was determined by dividing the calculated transmissivity by the saturated thickress of the aquifer at each well at the beginning of each test. 

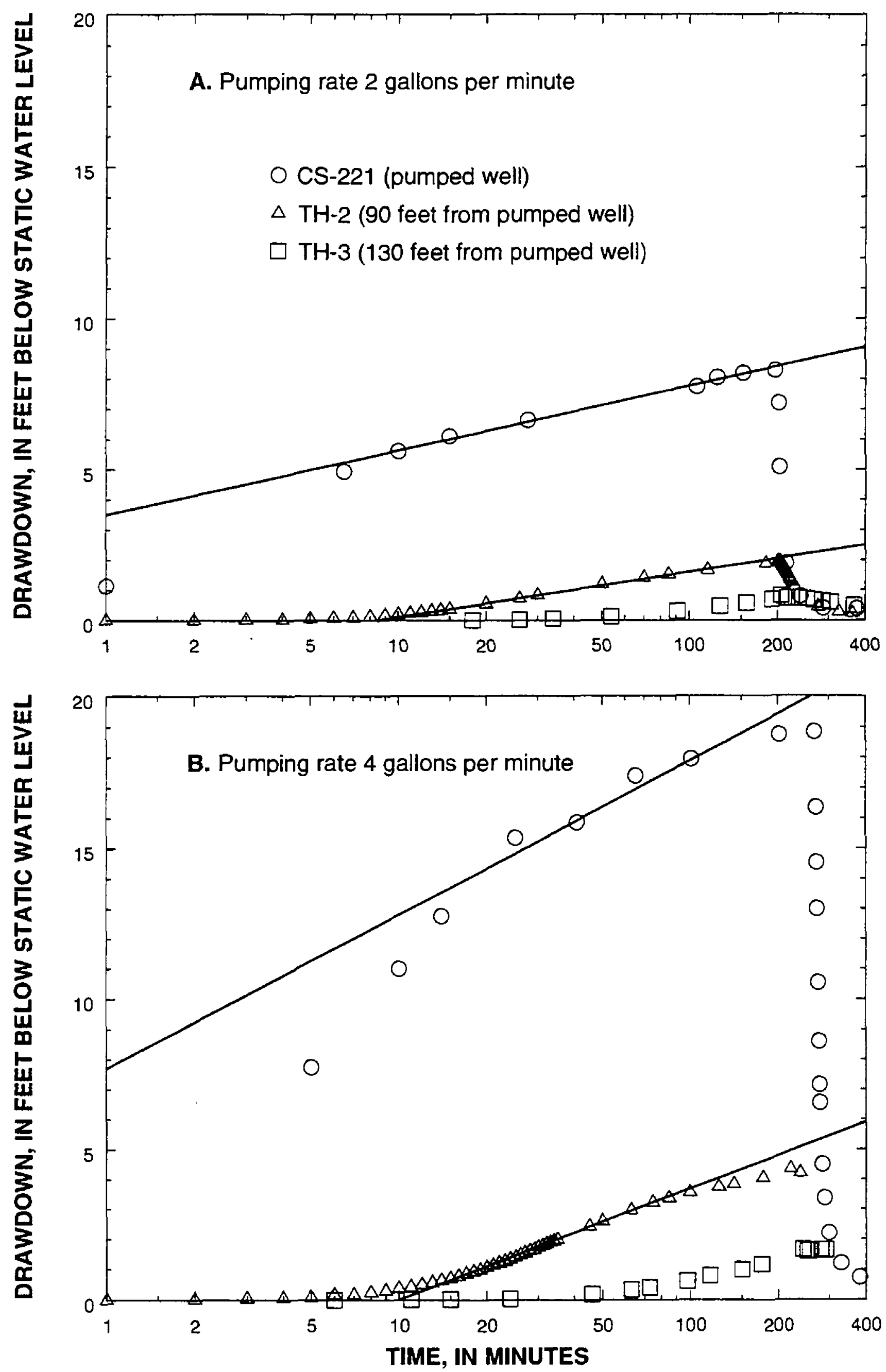

Figure 19. Drawdown of water level at $\mathrm{CS}-221, \mathrm{TH}-2$, and $\mathrm{TH}-3$ during aquifer tests of June 15 (A) and June 16, 1995 (B). Straight lines through data are for semilogarithmic determination of transmissivity. 


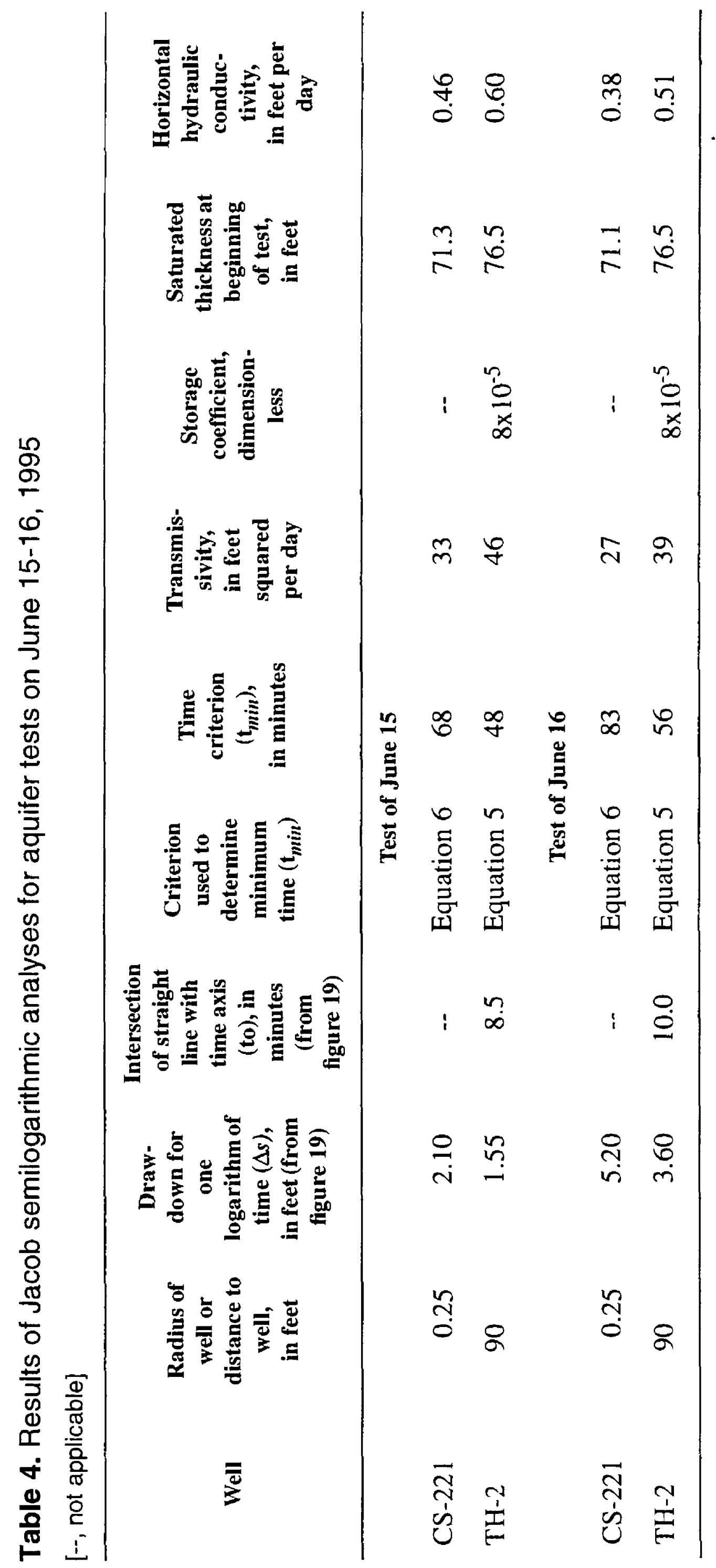


The eight calculated values of transmissivity range from 27 to $46 \mathrm{ft}^{2} / \mathrm{d}$, and the storage coefficients range from $8 \times 10^{-5}$ to $4.3 \times 10^{-4}$. Horizontal hydraulic conductivities of the aquifer over its entire saturated thickness range from 0.35 to $0.60 \mathrm{ft} / \mathrm{d}$. Actual fracture-zone widths are on the order of $0.5 \mathrm{ft}$; therefore, hydraulic conductivities of these zones range from 54 to $92 \mathrm{ft} / \mathrm{d}$ and are higher for zones less than $0.5 \mathrm{ft}$ thick. Estimates of the two properties are fairly consistent between the two tests and between the two analysis techniques. The estimates of transmissivity fall within the range of transmissivity reported for similar sedimentary rocks at a site of ground-water contamination in Durham, Conn. (Melvin and others, 1995, p. 51) and are similar to those reported by others for similar sedimentary rocks (mudstones, siltstones, and sandstones) of the Passaic Formation of New Jersey (Morin and others, in press).

Ground-water samples were collected in the study area during the aquifer-testing period, the week of June 13-17, 1995. On June 13-14, before pumping at CS-221 began, water samples were collected at TH-1, TH-2 (two samples at depths of 25 and $40 \mathrm{ft}$ below top of casing), TH-3, CS-221 (at a depth of $50 \mathrm{ft}$ below top of casing), HOLO-1, HOLO-5, HOLO-6, SW-1, SW-2, A-2, A-3, and A-5. Samples were collected using a teflon bailer and analyzed using a portable gas chromatograph equipped with a photoionization detector (S. Clifford, U.S. Environmental Protection Agency, written commun., 1995). Most samples contained no detectable contaminants. However, a water sample from HOLO-5 contained a DCE concentration of $0.8 \mu \mathrm{g} / \mathrm{L}$ and a PCE concentration of $3.9 \mu \mathrm{g} / \mathrm{L}$; a water sample from SW-1 had a toluene concentration of $0.3 \mu \mathrm{g} / \mathrm{L}$; and a water sample from A-5 had a toluene concentration of $30 \mu \mathrm{g} / \mathrm{L}$. Also, a strong petroleum odor and an oily sheen on the surface of the standing water was noted at well A-5. One water sample was collected from CS-221 during the aquifer test on June 15, and three samples were collected during the aquifer test on June 16. In all four samples, DCE was found at concentrations of 0.8 to $1.2 \mu \mathrm{g} / \mathrm{L}$. Two water samples were collected at well TH-3 before and after the aquifer test of June 16. Two samples also were collected at well TH-2 after the aquifer test of June 15 and during the aquifer test of June 16. No volatile organic constituents were detected in the samples collected from these two wells.

Heat-pulse flowmeter measurements were made in TH-1, TH-2, TH-3, and CS-221 under nonpumping and single-well pumping conditions. Measurements made under nonpumping conditions indicated that there was virtually no consistent, measurable flow in the boreholes; thus, the vertical hydraulic gradient was very low in those wells. Measurements made in each well as the well was being pumped (single-well pumping conditions) indicated that flow occurred in fissile zones and high-angle fractures. Fissile zones and high-angle fractures usually are indicated on caliper logs by an abrupt increase in borehole diameter. Fissile zones and high-angle fractures were distinguished from each other using continuous cores, boreho'e television, and acoustic televiewer logs. All measurable borehole flow in CS-221 occurred at a high-angle fracture (fig. 20). Flow in TH-1 was associated with a highly broken (perhaps weathered) zone near the top of the well (fig. 21). Flow in TH-2 was associated with two fissile zones (fig. 22). Although the upper fissile zone in TH-2 is not well defined on the caliper $\log$, it was present in the core and visible on the television log. When TH-3 was pumped at the same rate as $\mathrm{TH}-2$ or CS- $221(0.5$ to $1.0 \mathrm{gal} / \mathrm{min})$, the water level in the well did not stabiliz:, consequently the pumping rate was lowered to about $0.25 \mathrm{gal} / \mathrm{min}$. Even at this reduced pumpirg rate, a fissile zone which probably contributed to flow was located above the water level in the we"! during pumping and could not be measured. Mcst of the flow entered the well from a fissile zone at an altitude of about $110 \mathrm{ft}$ (fig. 23). The flowmeter tests during pumping indicate a lower specific capacity at $\mathrm{TH}-3 \quad(0.018(\mathrm{gal} / \mathrm{min}) / \mathrm{ft})$ than at $\mathrm{TH}-2$ $(0.053(\mathrm{gal} / \mathrm{min}) / \mathrm{ft})$.

Hydraulic testing of wells $\mathrm{TH}-2, \mathrm{TH}-3$, and CS 221 indicates that the hydraulic properties of the aquifer near the boreholes differ from well to well. A higher rate of borehole flow was observed in TH-2 than in TH-3 during the June 15-16 aquifer test. This may indicate that the hydraulic connection is better between TH-2 and CS-221 than between TH-3 and CS-221. Also, it was noted that the specitic capacity of TH-2 is higher then that of TH- 3 by a factor of three. The specific canacity of 
both wells is lower than that of CS-221 by a factor of ten, possibly because of differences in the drilling method or because the water in CS-221 flows from a high-angle fracture, which intersects several fissile zones.

Heat-pulse flowmeter measurements made in observation wells $\mathrm{TH}-2$ and $\mathrm{TH}-3$ during the June aquifer test (multi-well heat-pulse flowmeter logs on figs. 22 and 23) showed that the aquifer system is formed by connected fissile zones and high-angle fractures. While CS-221 was pumped, water entered $\mathrm{TH}-2$ at the upper fissile zone, flowed downward through the borehole, and flowed out at the lower fissile zone (fig. 24). Under the same pumping conditions, water entered $\mathrm{TH}-3$ at the upper fissile zone, flowed downward through the borehole, and flowed out at the lower fissile zone (fig. 24). No measurements of borehole flow were made in CS-221 during the aquifer test because the well was not large enough to accommodate the pump, discharge line, and the heat-pulse flow meter; however, the only source of water to CS-221 under single-well pumping conditions was the higl -angle fracture (fig. 20) and the same flow condition spobably existed during the aquifer test, even though the test was conducted at a higher pumping rate ( $2 \mathrm{gal} / \mathrm{min}$ ) than the single-well test $(1 \mathrm{gal} / \mathrm{min})$. Water must enter the high-angle fracture in the area between CS-221 and TH-2 and between CS-221 and TH-3 where it intersects the water-bearing fissile zones present in TH-2 and TH-3 (fig. 24). The total volumetric flow measured in $\mathrm{TH}-2$ $(0.047 \mathrm{gal} / \mathrm{min})$ was three to four times greater than that in TH-2 $(0.014 \mathrm{gal} / \mathrm{min})$. 


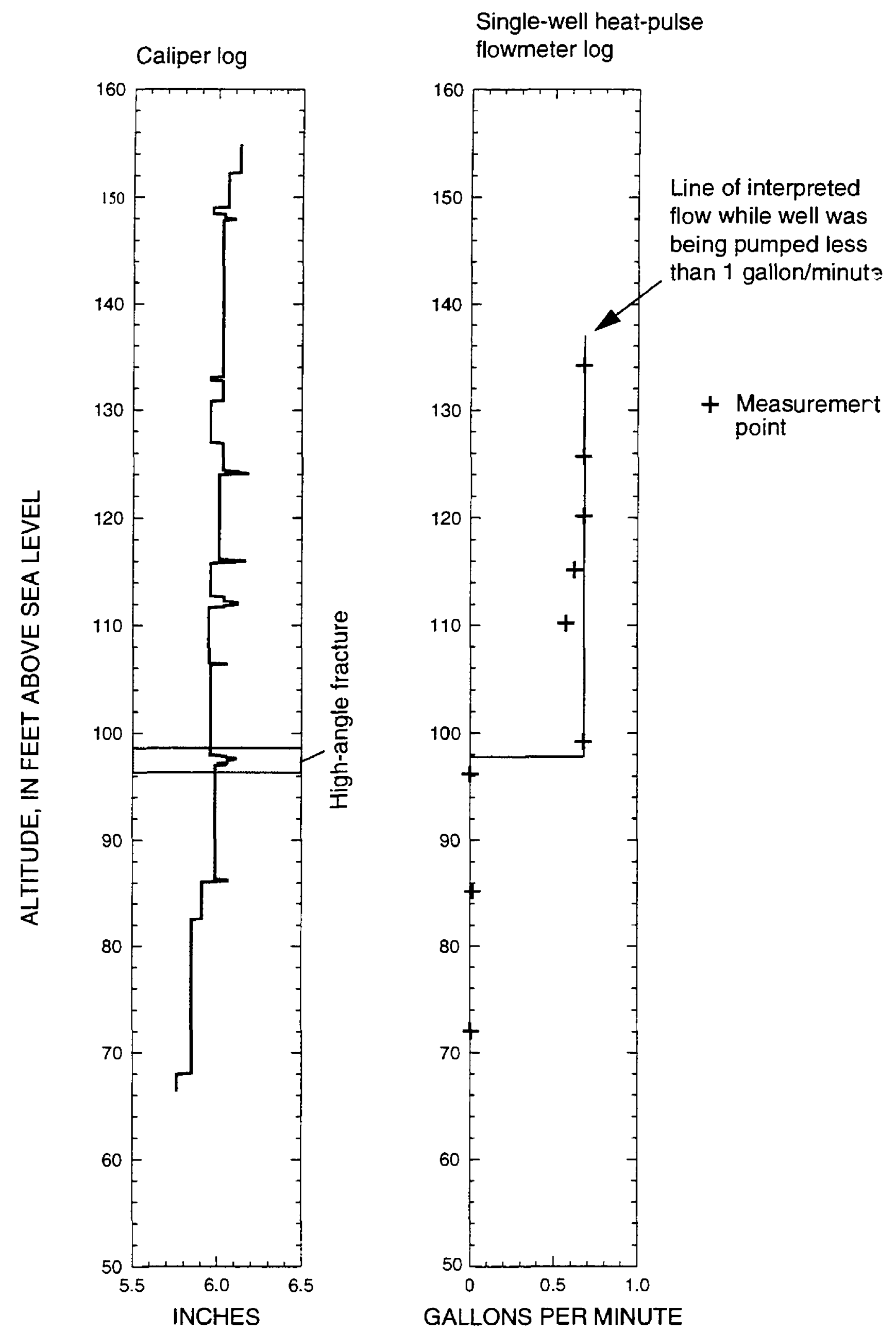

Figure 20. Caliper log and single-well heat-pulse flowmeter log at well CS-221, Cheshire, Connecticut 


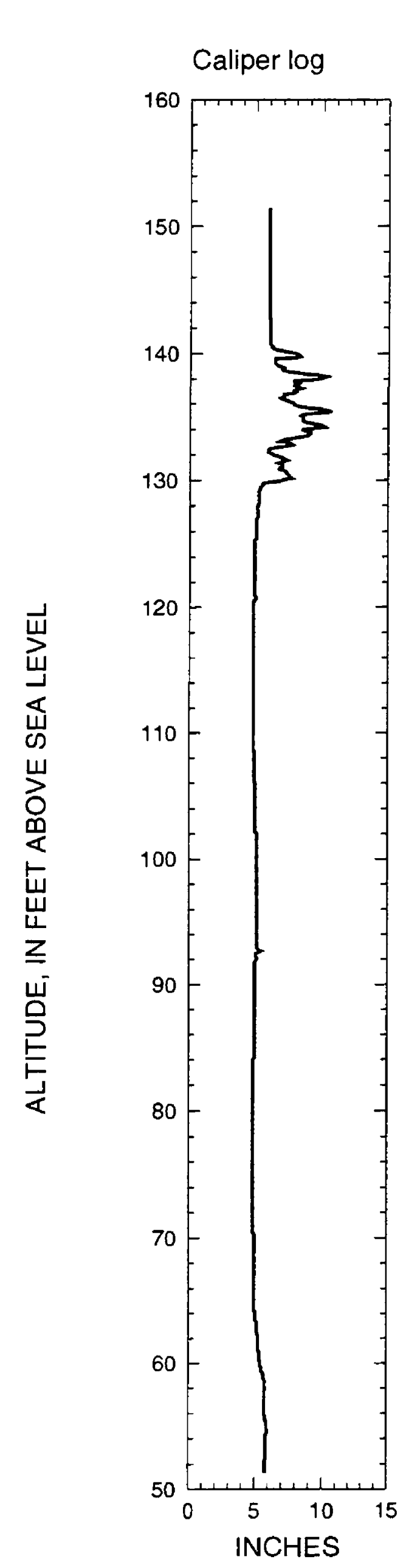

Single-well heat-pulse flowmeter log

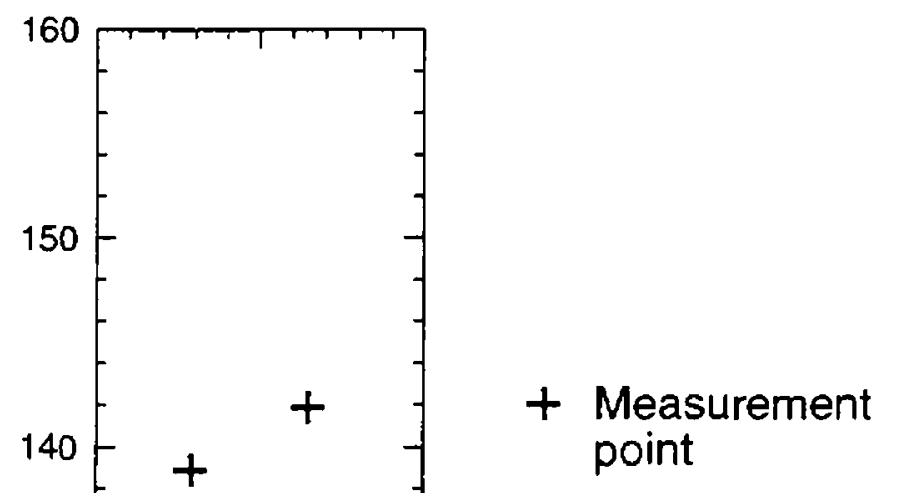

Figure 21. Caliper log and single-well heat-pulse flowmeter log at well $\mathrm{TH}-1$, Cheshire, Connecticut. 


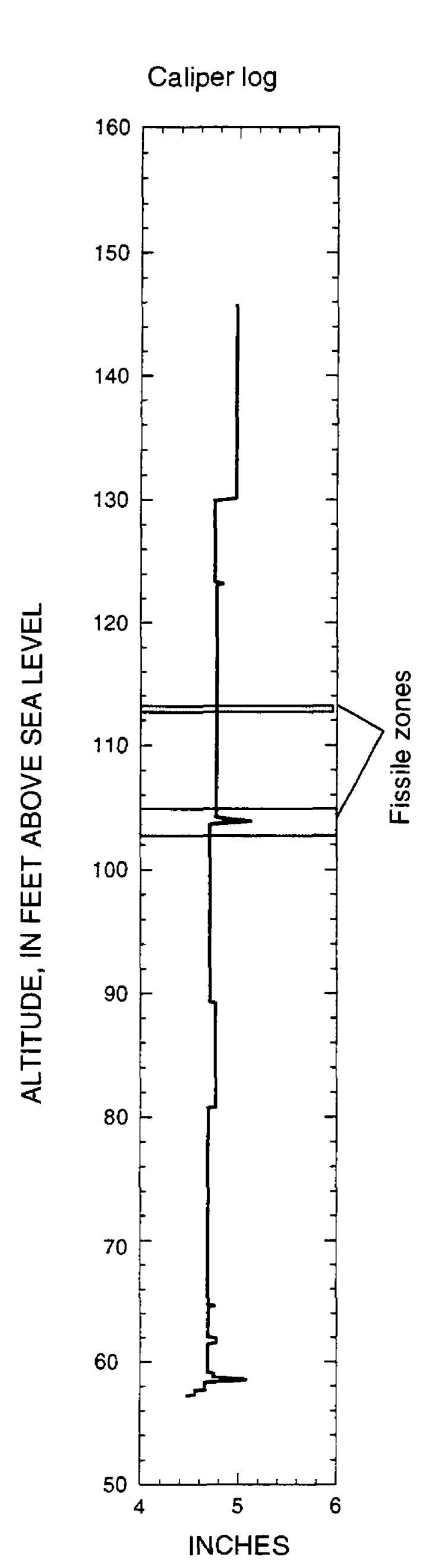

Single-well heat-pulse flowmeter log

Multi-well heat-pulse flowmeter log
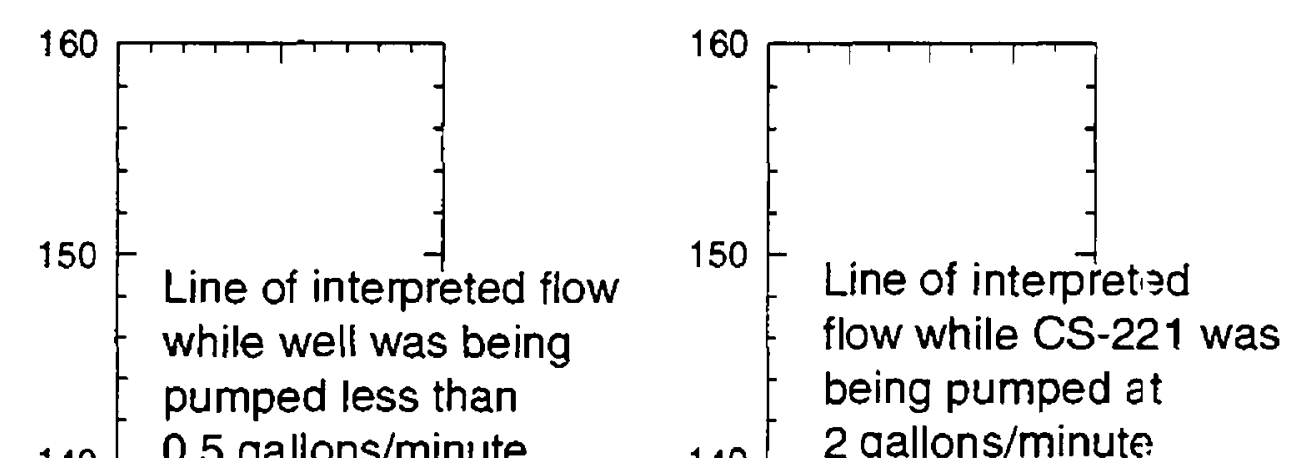

140 while well was being pumped less than 0.5 gallons/minute

+ Measurement point
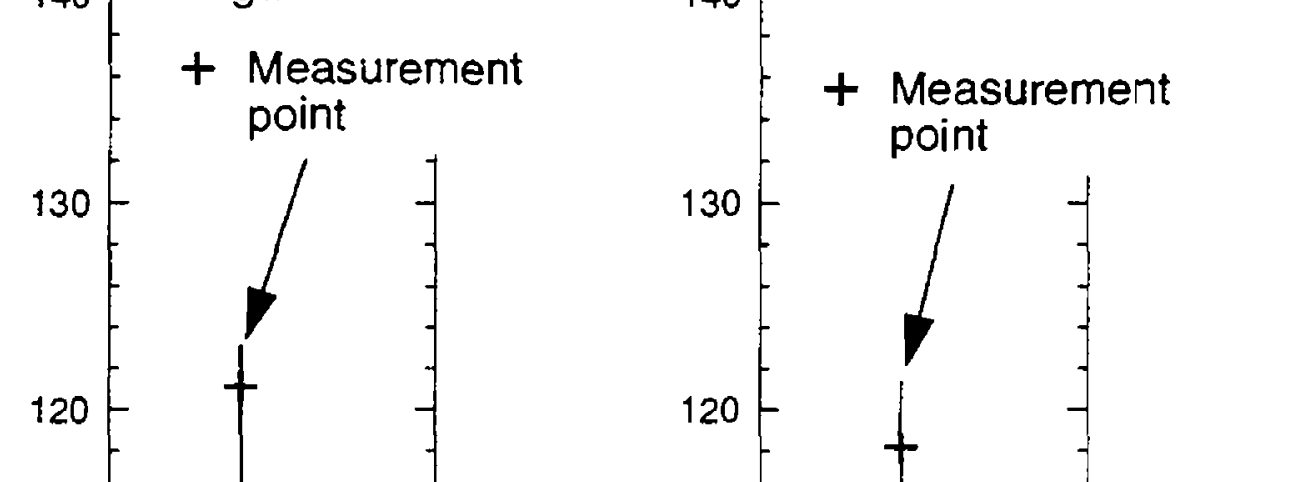

Figure 22. Caliper log and single-well and multi-well heat-pulse flowmeter logs at well TH-2, Cheshire, Connecticut. 

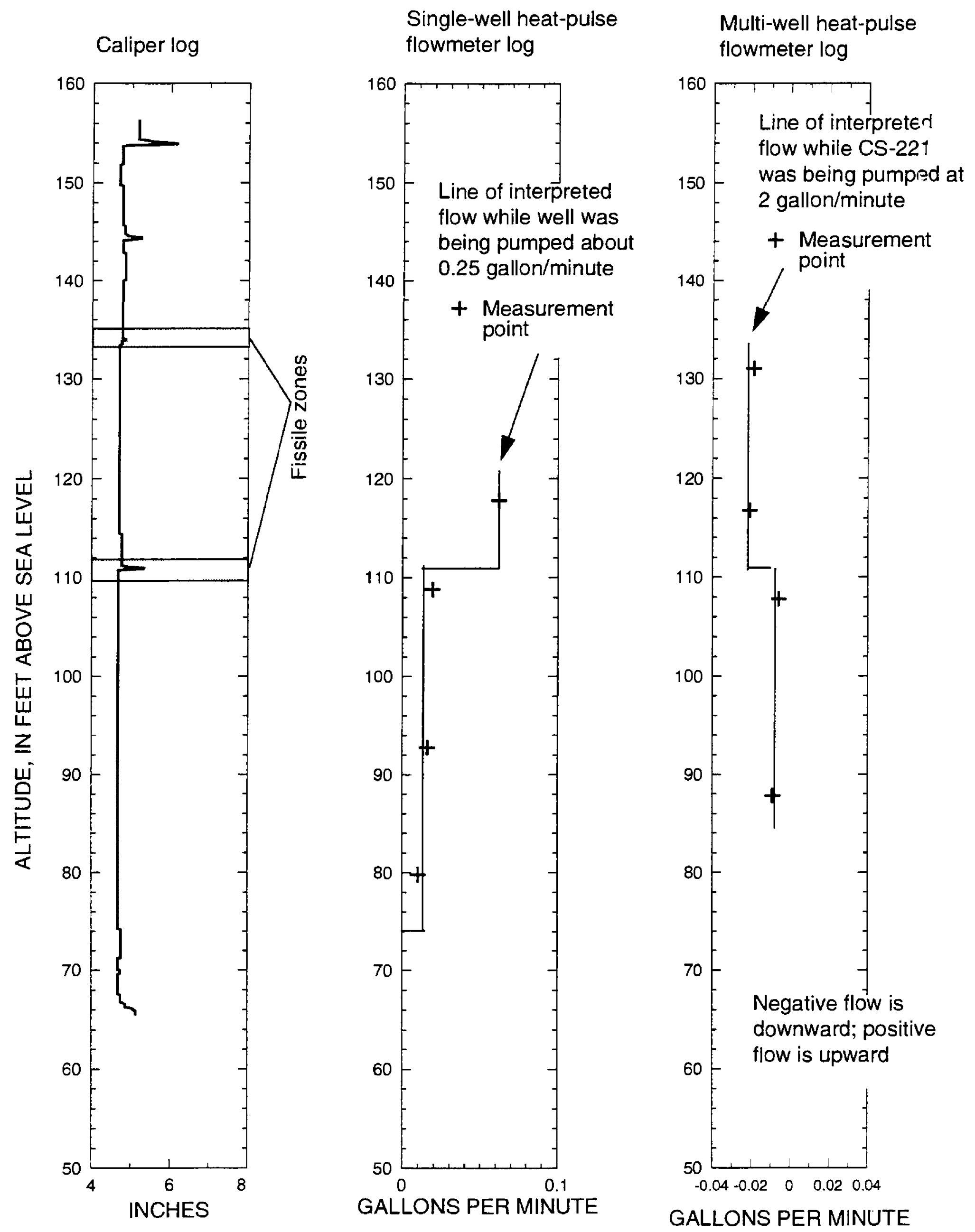

Figure 23. Caliper log and single-well and multi-well heat-pulse flowmeter logs at well TH-3, Cheshire, Connecticut. 


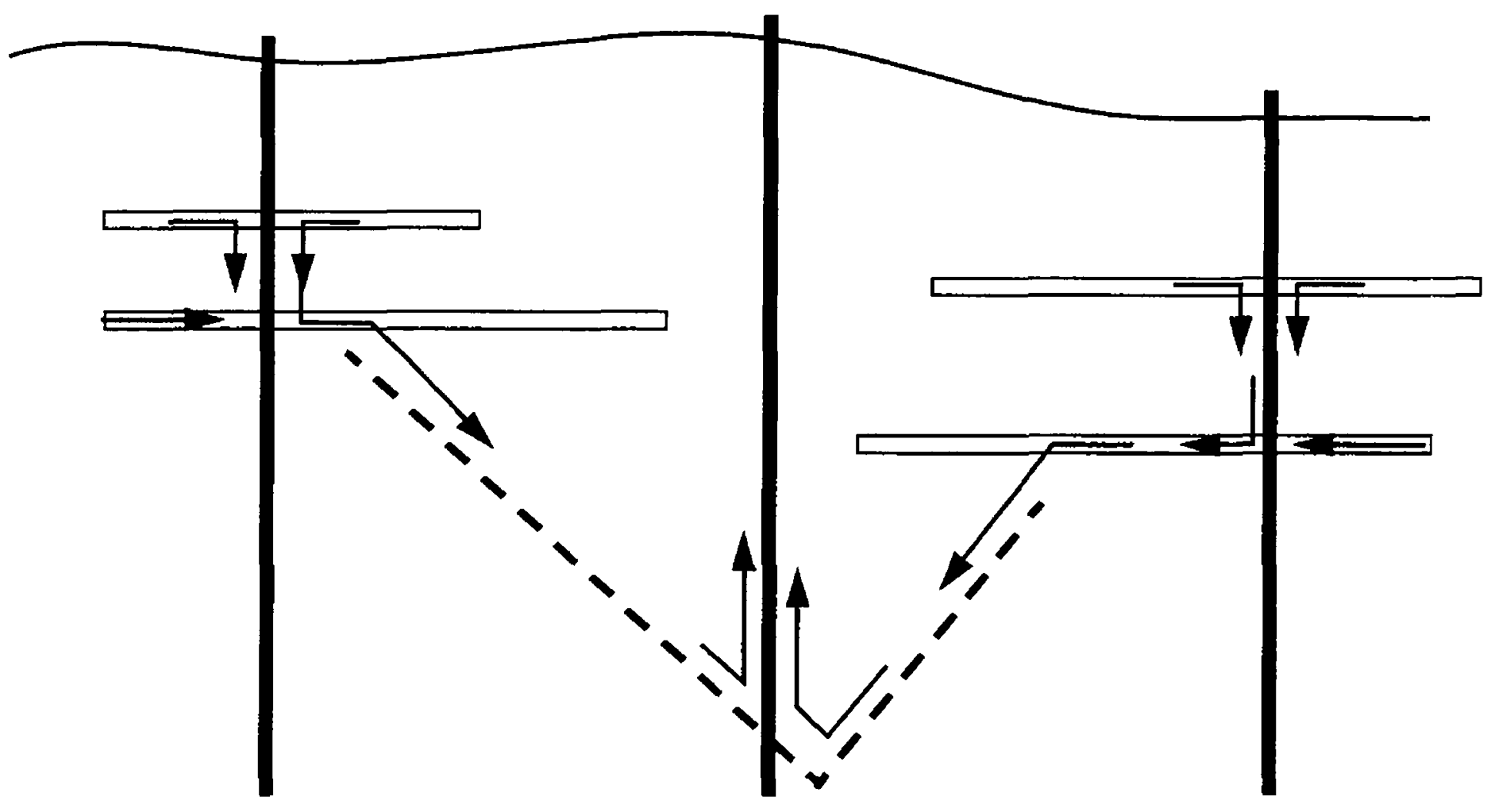

NOT TO SCALE

\section{EXPLANATION}

Fissile zone, broken where no hydraulic connection can be inferred from flowmeter logs

Plane of high-angle fracture, projected onto

- $\ldots$ line of section

Ground-water-flow direction inferred from heat-pulse flowmeter measurements

(figs. 20-23)

Figure 24. Schematic section showing ground-water flow during pumping of CS-221, Cheshire, Connecticut. 


\section{CONCEPTUAL MODEL OF GROUND- WATER FLOW}

Three scales of ground-water flow have been identified for areas of the Quinnipiac River Basin by Mazzaferro and others (1979). The first scale consists of local flow systems, which are small ground-water-flow systems that develop around ponds, small streams, and swamps and are in existence only a few months of the year. The second scale consists of subregional flow systems that are moderately large systems generally confined to areas drained by perennial streams, including Judd Brook, Tenmile River, and the Quinnipiac River. Mazzaferro and others (1979) characterize these subregional systems as those that extend vertically downward to depths at which the bedrock has no interconnected fractures. These subregional flow systems are the most significant with respect to hydrologic analyses and are the ones most frequently tapped for ground-water supplies. A third, deeper (or regional) flow system is defined by ground-water flowpaths that extend under one or more major surface-water drainage divides.

Steady-state ground-water flow in bedrock and fine-grained unconsolidated deposits in the Cheshire regional area was simulated to (1) determine if existing estimates of hydraulic conductivity and recharge are compatible with the subregionalflow-system concept of Mazzaferro and others (1979), (2) determine the lateral extent and depth of subregional ground-water flowpaths, (3) estimate the rate and direction of ground-water flow along subregional flowpaths, and (4) visualize the effect of geologic heterogeneity on ground-water flow. The approach used to meet the first three objectives was to simulate ground-water flow over a large area (the regional model), using a numerical simulation code known as MODFLOW (McDonald and Harbaugh, 1988). To meet the fourth objective, flow was simulated over a much smaller area (the generalized local-scale model).

\section{Regional-scale model}

The regional model area (fig. 25) is similar in extent to the regional study area (fig. 1). The regional model was based in part on two hypotheses: (1) the average hydraulic conductivity and recharge is the same everywhere in the region; and (2) that a large enough block of aquifer (called a Representative Elementary Volume, or REV) is sufficiently fractured for the fracture system to act as a porous medium, and ground-water flow can be described by Darcy's Law. The first hypothesis was assumed to be true because the rocks through out the regional area are geologically similar, except for the West Rock Diabase. The diabase is not areally extensive (see figs. 3 and 5) and is unlikely tc affect average regional properties, even though it might have an effect on ground-water flowpaths in the south-central part of the model grid. It would be difficult to prove the second hypothesis; however, if the results of the regional simulation were extremely unreasonable, the hypothesis woult most likely not be valid.

The model grid and boundary conditions were selected to be consistent with the amcunt of available data, time constraints on the study, and the stated purposes of the study. The model grid has 100 columns, 100 rows, and 4 layers. The column and row spacing represents a uniform $250 \mathrm{ft}$, and the layer spacing represents a uniform $100 \mathrm{ft}$, except the top layer (layer 1), which is a wate--table layer and has a variable thickness. The bottom of layer 1 is at a uniform altitude of $100 \mathrm{ft}$; the $\mathrm{t}$ ottom of the layer 2 is at sea level, and so on through the remaining layers. Materials present above sea level (layers 1 and 2) include coarse-grained glacial deposits, fine-grained glacial deposits, and bedrock (fig. 5). In this study, coarse-grained glacial deposits were not simulated. The typical horizontal hydraulic conductivity of coarse-grained glacial deposits is approximately one hundred times the hydraulic conductivity of fine-grained glacial deposits and sedimentary rock. Because of th's contrast, ground-water flowpaths in the coarse-grained glacial deposits would tend to be horizontal and to discharge to perennial streams rather than into bedrock or fine-grained glacial deposits. For example, ground-water flow in the large sand deposit near Route 10 (fig. 5) is probably horizontal toward Tenmile River and the Quinnipiac River. Thus, the flow system in most coarse-grained glacial depcsits is superimposed on deeper flow systems and can be omitted for the purposes of this study. Other coarsegrained glacial deposits, such as the sand and gravel west of I-84 (fig. 5), are thin and small ir areal extent relative to the scale of the simulated area and also can be omitted. Fine-grained glacial deposits (including till) and bedrock were combined for layers 1 and 2 because their hydraulic properties are similar. Layers 3 and 4 represent only bedrock. 


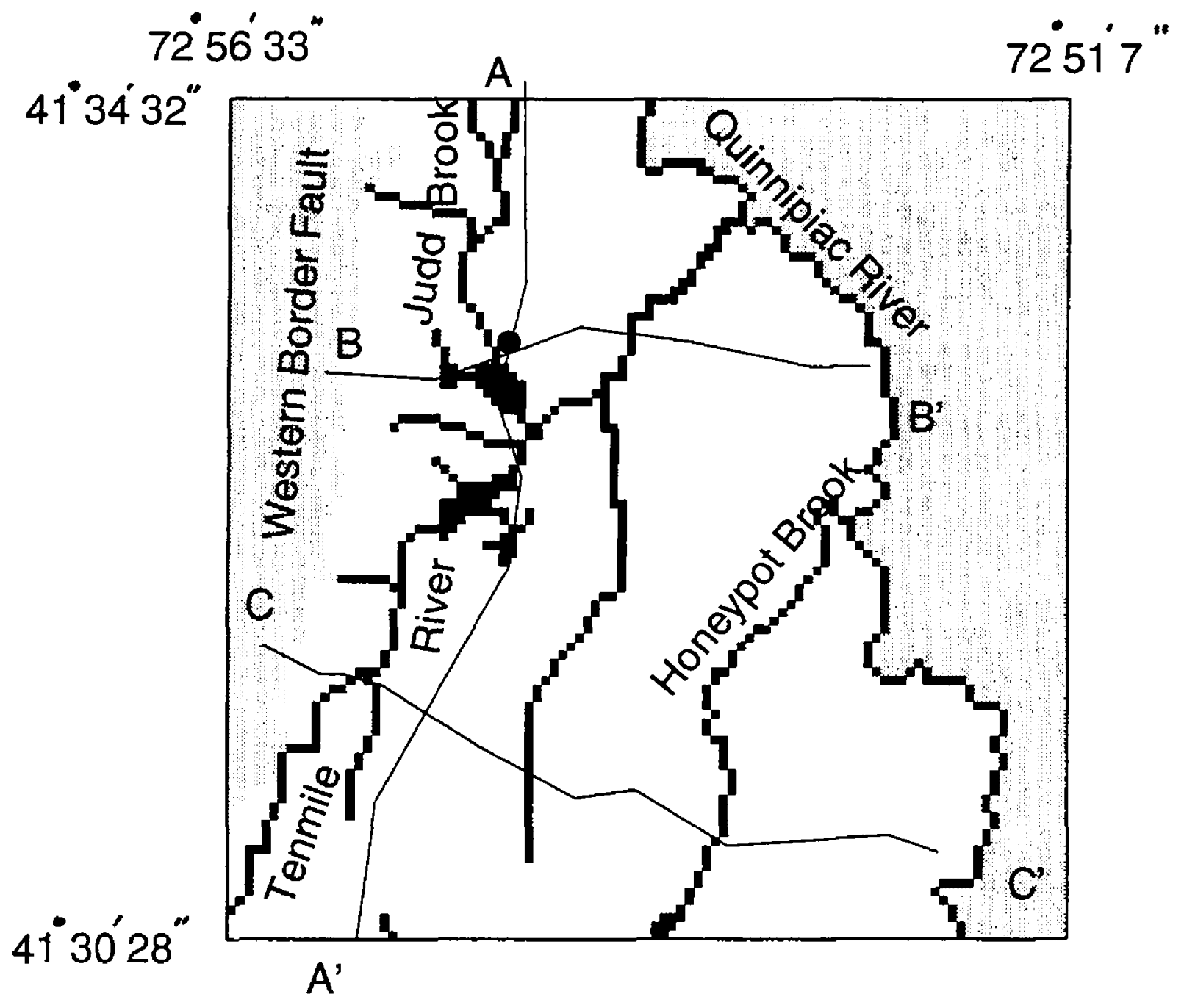

EXPLANATION

Active model grid cell

Inactive model grid cell

D Constant-head cell

Cheshire site

Figure 25. Model grid and boundary conditions for the regional model at the Chsshire study area, Cheshire, Connecticut. 
The active model grid extends from the western border fault to the Quinnipiac River (fig. 25) and from the headwaters of Judd Brook to the north and Tenmile River to the south. These boundaries roughly approximate the drainage areas of Judd Brook, Tenmile River, Honeypot Brook, and an unnamed tributary of Tenmile River (fig. 25) that are underlain by sedimentary rocks. The groundwater basin was assumed to have a similar areal extent, with the following exception. An area that is underlain by crystalline bedrock west of the western border fault was excluded from the model for two reasons. First, much of the area underlain by crystalline rock is very steep and has a thin cover of till; thus, recharge would be much smaller than in areas underlain by sedimentary rock, which tend to be much flatter. Second, much of the area underlain by crystalline rock drains internally into lakes and (or) impoundments that are local ground-water discharge areas. The western border fault, which separates the two rock types, is considered to be essentially a no-flow boundary. The north and south model boundaries, which approximate groundwater flowpaths, also are considered to be no-flow boundaries.

The source of ground water to the region is recharge from precipitation; the discharge of ground water is primarily to streams that drain the area. A uniform recharge rate of $8 \mathrm{in} / \mathrm{yr}$ was applied to the entire modeled area. This rate reflects estimated recharge rates in till and bedrock settings in Connecticut (Melvin and others, 1995). In areas underlain by coarse-grained glacial deposits, this rate reflects only the water that passes from the coarse material into the underlying bedrock or finegrained glacial material. Ground water discharges to the Quinnipiac River, Judd Brook, Tenmile River, Honeypot Brook, and an unnamed tributary of Tenmile River (fig. 25); these streams are represented by constant-head cells. The hydraulic head at each constant-head cell was set to the altitude of the water surface, which was estimated by using the 30-m-resolution digital-elevation-model (DEM) data for the Southington and Meriden quadrangles. In the Cheshire regional area, the DEM does not accurately represent land surface in the relatively flat valley bottoms; however, it does represent the main topographic features at the regional scale.
An estimate of regional average hor zontal hydraulic conductivity was used to construct a regional model. There are few reported values of horizontal hydraulic conductivity of fine-grained deposits and bedrock in the area, and this is a source of uncertainty in the regional model. The horizontal hydraulic conductivity used in all layers of the regional model was $0.40 \mathrm{ft} / \mathrm{d}$ based on a range of 0.35 to $0.60 \mathrm{ft} / \mathrm{d}$ calculated from two aquifer tests conducted at the Cheshire study area. The hydraulic conductivity at the regional scale was assumet to be equal in all directions; this assumption was te ted in a sensitivity analysis.

Simulated hydraulic heads and flows were compared to land-surface altitudes from the DEM data and measured streamflow, respectively, to show that the model was reasonable (fig. 26). The model was considered reasonable if simulated water levels were between stream-surface altitude and land-surface altitude. In some discharge areas, the simulated hydraulic heads seem to be above land surface because the cross section did nct necessarily pass through the point on the DEM that was used as the constant-head value at a stream. In general, however, the simulated water table was a subdued replica of the land surface, a condition that is generally true of water-table altitudes. The groundwater contribution to streamflow upstream from streamflow-gaging stations was less than 50 parcent of the lowest measured streamflow (table 1). This seems reasonable because most of the streamflow at low flow most likely represents discharge from coarse-grained stratified drift, and this discharge was not considered in the simulations.

In order to determine whether the regional model was reasonable, alternative simulations were run with plausible-but-different estimates of recharge and hydraulic conductivity. The resulting water-table altitudes were compared to land-surface altitude. The following changes in the model produced water-table altitudes that were signifi santly above land surface: horizontal hydraulic conductivity in the row direction (east-west) decreased by a factor of 10 relative to the column direction (northsouth); horizontal hydraulic conductivity ir both directions decreased by a factor of 10 ; recharge rate increased by $4 \mathrm{in} / \mathrm{yr}$; and vertical hydraulic ccnduc- 


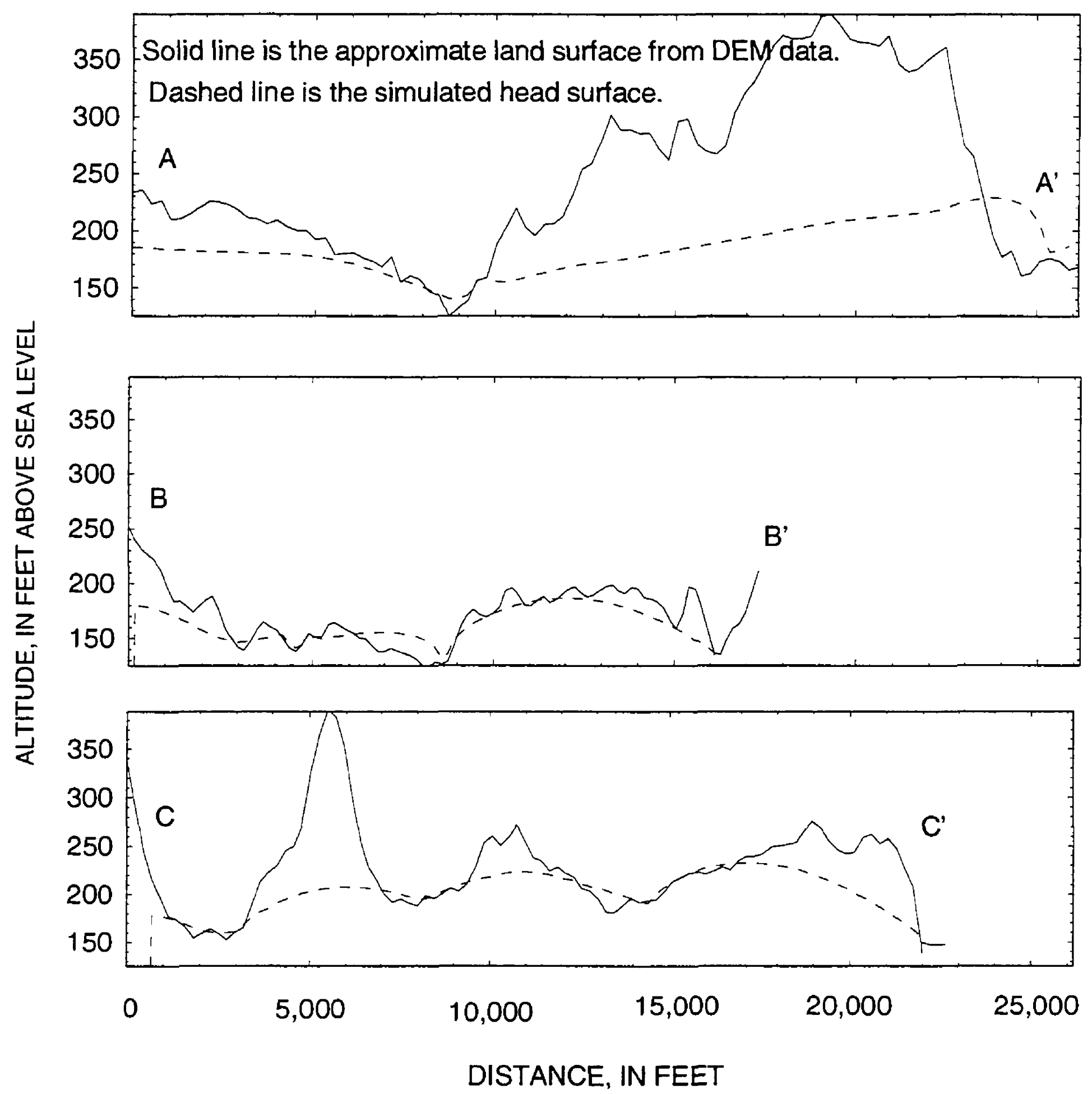

Figure 26. Relation of simulated heads to land surface at the Cheshire study area, Cheshire, Connecticut. 
tivity decreased by a factor of 10 . Lowering the recharge rate by $4 \mathrm{in} / \mathrm{yr}$ and increasing the horizontal hydraulic conductivity by a factor of 10 resulted in water flowing from the streams into the aquifer; this is not likely because streams may lose flow where they flow over coarse-grained deposits above the water table, but not generally where they flow over fine-grained sediments in valley bottoms.

In this regional simulation, the fine-grained glaciolacustrine deposits were considered to have similar hydraulic properties to glacial till and bedrock. A possible refinement to the model might be to use a recharge rate through fine-grained glaciolacustrine sediments lower than the one used in this model. In the alternative simulations, the effects of changing two parameters simultaneously were not considered. In other words, offsetting changes in two parameters could produce the same water-table altitudes as did the regional model. In general, however, the alternative simulations were less satisfactory than the regional model simulations.

Ground-water flowpaths were illustrated by particle tracking (fig. 27), which shows that the regional model is dominated by subregional-scale flow systems (Mazzaferro and others, 1979) in which perennial streams form hydrologic divides that separate the region into smaller flow systems. Local flow systems, which are in existence only a few months of the year, were not simulated. Regional-scale flow systems were not evident from the particle tracking because the model was too general to detect less prominent regional flowpaths. Factors that may increase the prominence of regional-scale flowpaths include (1) hydrologic stresses that produce large hydraulic gradients, such as pumping; (2) large, extensive horizontal faults or fractures; and (3) deep flow from areas underlain by crystalline rock. Paths of ground-water flow are much longer and deeper, and ground-water flow is slower regionally than subregionally.

The regional-scale model also was used to estimate the average linear velocity of ground-water flow in the study area. The average linear velocity is the rate at which a particle placed in the groundwater-flow system would travel with no dispersion, or, the average rate at which a cloud of particles would travel with dispersion. In the 250 -by-250 ft cell containing CS-221, simulated ground-water flow was $0.4 \mathrm{ft} / \mathrm{d}$ (coincidentally, the same as hydraulic conductivity) in a direction $\mathrm{S} .42^{\circ} \mathrm{W}$. (fig. 28), using a bulk porosity of 0.02 , which was obtained from square-array resistivity measurements in the study area. The typical horizontal and vertical lengths of flowpaths that pass through CS-221 were approximately $1,000 \mathrm{ft}$ and $100 \mathrm{ft}$ respectively. The actual ground-water flow paths are highly controlled by the spacing, orientation, and hydraulic conductivity of fractures and wocld not appear as illustrated in figure 28 .

\section{Generalized local-scale model}

Solute transport in the study area is dominated by features smaller than the size of a modelgrid cell in the regional model. To test the effects of generalized local-scale features on ground-water flow, a second model-based on geologic and geophysical investigations in the area-was used to visualize ground-water flow in a hypothetica ${ }^{1}$ aquifer system that was consistent with observations in the area. Use of the simulation to predict hydraulic heads was not possible because of the paucity of points at which the orientation and magnitude of the hydraulic conductivity was known. Visualizing ground-water flow in fractured rock is difficult because the direction of hydraulic gradient and hydraulic conductivity are not necessarily coincidental, and this can produce preferential flow'paths that are spatially complex.

The generalized local-scale model was based in part on the hypothesis that ground-water f'ow in fracture zones at the local scale can be described by Darcy's Law, as discussed in the section "Response of the Fractured-Bedrock Aquifer to Hydraulic Stresses." The REV in the generalized local-scale model is a smaller block completely composed of discrete zones that contain fissile zones, high-angle fractures, or unfractured rock matrix, rather than a large homogeneous block of fractured rock as in the regional-scale model. The flow system at the generalized local scale was made as realistic as possible given the available data; however, this sime?ation should not be used to predict ground-water fow in the study area. 


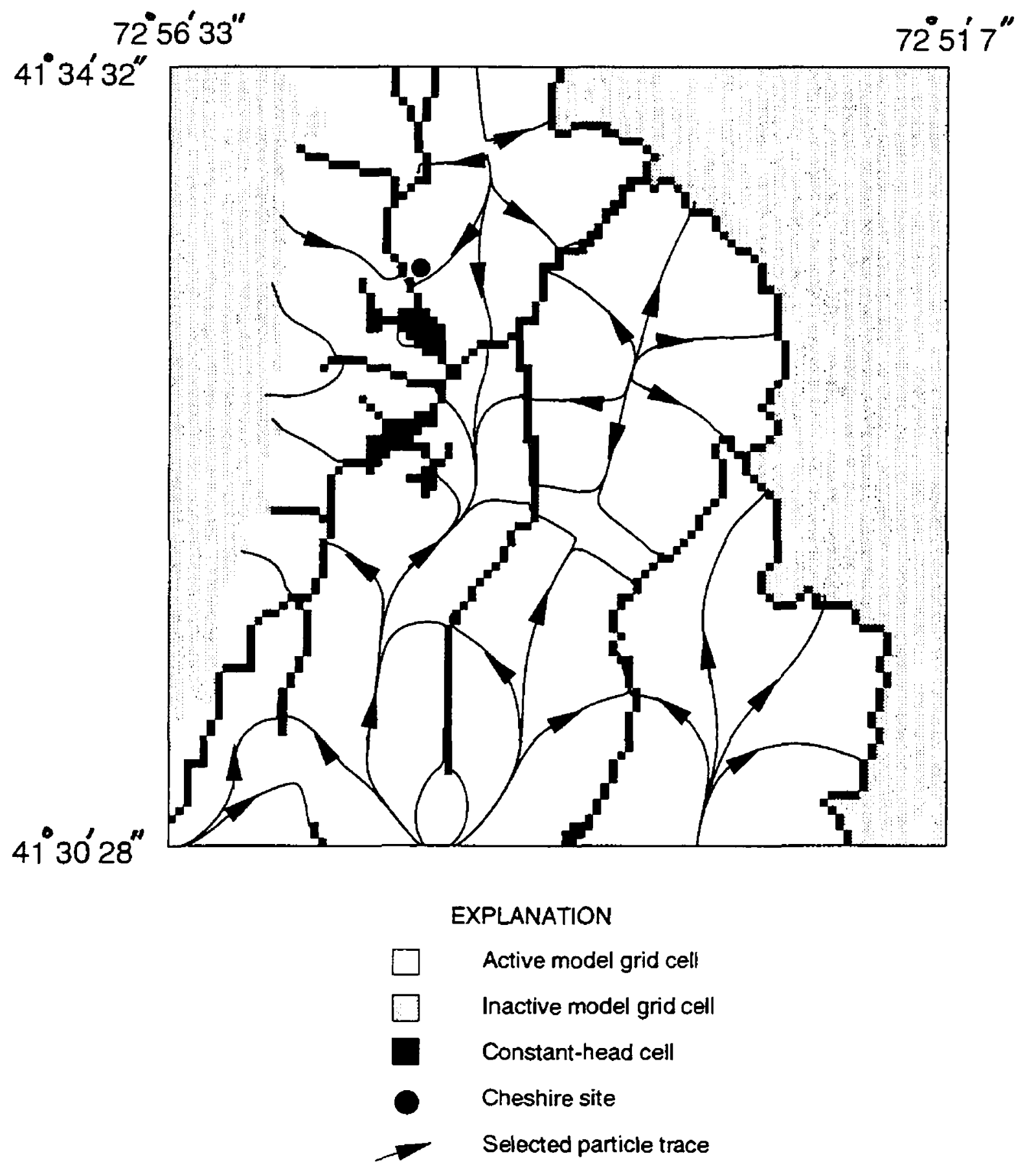

Figure 27. Particle traces and extent of local ground-water flow systems within the regional model at the Cheshire study area, Cheshire, Connecticut. 


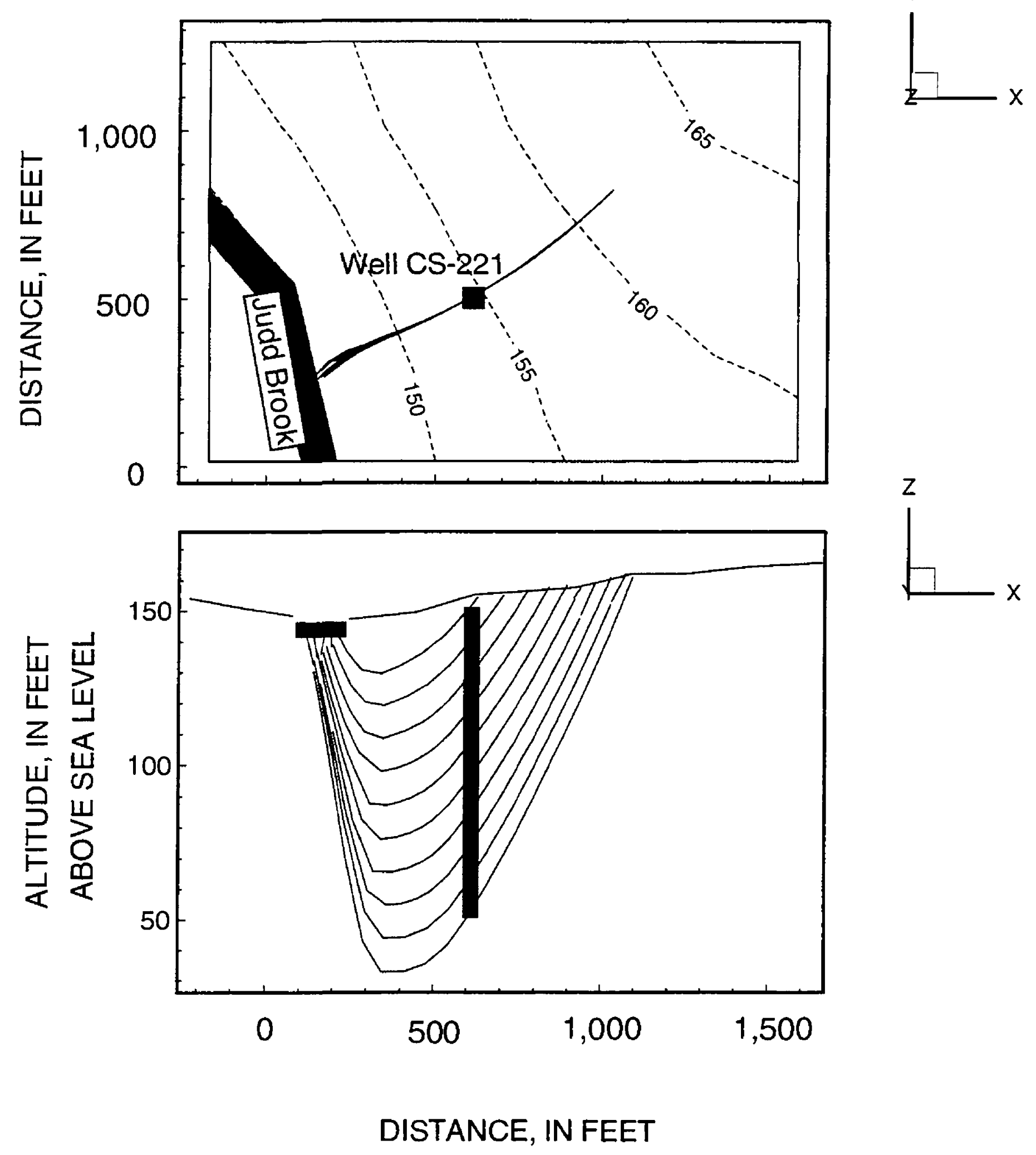

\section{EXPLANATION}

- - - - WATER TABLE CONTOUR--Altitude of simulated water table in feet above sea level. Contour interval 5 feet

Particle trace

Figure 28. Particle traces through CS-221, Cheshire, Connecticut. 
Field data indicate that the aquifer system consists of alternating beds of fine- and coarsegrained rock (see fig. 9), each of which have a characteristic type of fracture. Ground water flows in the fine-grained rock units in fissile zones that are parallel to bedding. Ground water also flows in high-angle fractures that are perpendicular to bedding. The high-angle fractures generally do not extend through the fine-grained rock; however, some fractures do reach a fissile zone within the fine-grained rock. Many more fractures were observed in outcrop and in wells than were included in the model because field data showed that only a small subset of these fractures were hydraulically significant. The combined fracture types form an aquifer system in which ground water follows a stair-step flowpath horizontally through fissile zones and vertically through high-angle fractures.

The average spacing of hydraulically significant features was estimated from the frequency of their occurrence in TH-2, TH-3, and CS-221. Fewer dipping features are intercepted by a vertical well than would be intercepted by a line perpendicular to the feature. To correct for this, the corresponding perpendicular distance is calculated by multiplying the distance the well penetrates rock by the cosine of the dip angle. Wells TH-2, TH-3, and CS-221 were completed approximately $90 \mathrm{ft}$ into rock. The high-angle fractures dip at $60^{\circ}$ and the perpendicular distance is $45 \mathrm{ft}$; the fissile zones dip at $20^{\circ}$ and perpendicular distance is $85 \mathrm{ft}$. Three wells are used in this analysis, so the perpendicular distances are multiplied by three and divided by the total number of features in the three wells. The average spacing of the five fissile zones and one high-angle fracture (shown on figs. 20, 22, and 23) are $51 \mathrm{ft}$ and $135 \mathrm{ft}$, respectively. These values were used to develop a generalized local-scale model grid (fig. 29B). The model grid represented an area $200 \mathrm{ft}$ square, and model grid cells represented areas $10 \mathrm{ft}$ square, so there are 20 rows, 20 columns, and 20 layers. The model grid differs slightly from site conditions in the following ways: (1) fissile zones and high-angle fractures were simulated as $10 \mathrm{ft}$ thick, when in fact their true thickness is usually less; (2) high-angle fractures were simulated as striking in the same direction as fissile zones, when in fact their strikes are about $26^{\circ}$ apart; and (3) the average spacing of hydraulically significant features was used, but the averages were based on a small number of features and thus may be in error. Despite these dif'erences, the model grid is sufficient for the purposes of this study.

The generalized local-scale model grid corresponds to the area of the regional-scale mcdel containing CS-221 (row 29, column 36, layers 1 and 2 of the regional model). The volumetric flow rates from the regional model were assigned to fracture zones on the outside of the model grid. Flows from each face of the top layer in the regional motel were applied uniformly to fractures on the corresponding faces in layers $1-7$ of the generalized local-scale model, and flows from the second laye ${ }^{-}$of the regional model were applied in a similar fa shion to layers 8-20. The transmissivity of individual fracture zones was obtained by multiplying the hydraulic conductivity from the regional mode' by the thickness of each fracture zone. The nonfractured rock matrix was assigned a hydraulic conductivity two orders of magnitude lower than that of the fractures. The hydraulic conductivity of the roc' matrix is not known, but it is probably lower than the assigned value. A two order-of-magnitude contrast was used because the hydraulic gradient is low and the rock is essentially impermeable (Anderson and Woessner, 1992).

The simulated generalized local-scale ground-water-flow system was illustrate using traces from particles that were placed in a hypothetical well in the center of the model grid, $100 \mathrm{ft}$ from each side. The well was assumed to be ope 7 to two fissile zones-between altitudes of 20 to $30 \mathrm{ft}$ (upper flow zone) and between altitudes of -20 to $-30 \mathrm{ft}$ (lower flow zone). Twenty particles w'ere uniformly spaced along a vertical line in each zone and were traced forward and backward from their initial locations (fig. 29A and 29C).

Ground-water flow from each set of initial particle locations took place in two distinct flow zones, an upper flow zone and a lower flow zone. Although both flow zones included several fissile zones and high-angle fractures, mixing of water between the two zones was minimal. In fact, ground-water flowed in distinctly differert directions in each of the two flow zones-grourd water in the upper zone flowed to the west-southwest, and 


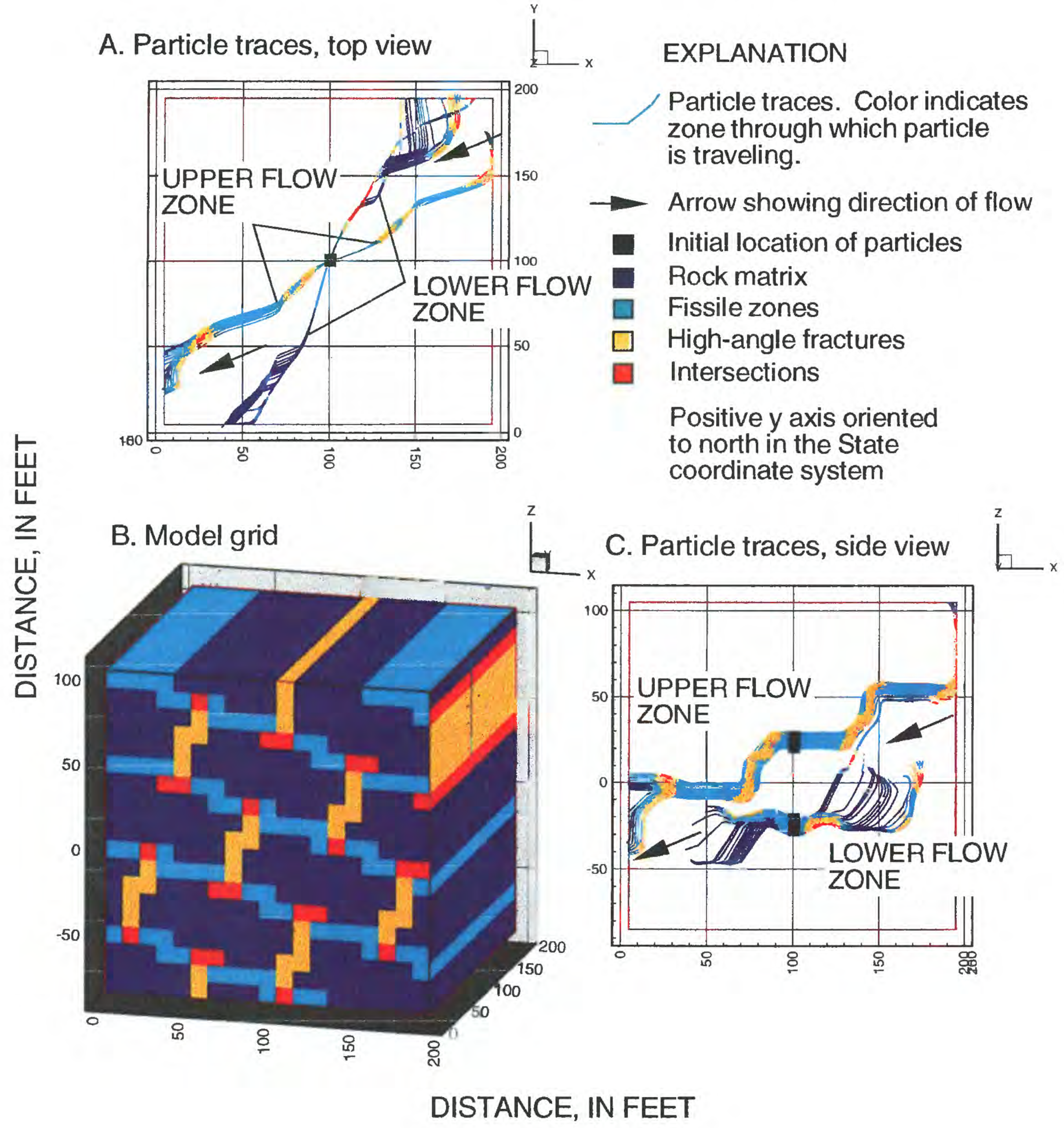

Figure 29. Particle traces through fractured media with fluxes from regional model. 
ground-water in the lower zone flowed south-southwest (fig. 29A). The stair-step pattern of flow was apparent in the upper zone but was less apparent in the lower zone. The sources of ground water to each zone were separate except for a small number of flowpaths to the lower zone that originated near the source of ground water to the upper zone. The lower zone received ground water mainly through the rock matrix, which is much slower than flow through fractures; therefore, if this were an actual well being sampled, the sample would not represent water quality in the lower zone. The upper flow zone received ground water from recharge at the water table as well as lateral inflow from fractures outside the modeled area. The lower flow zone received water from outside the modeled area through fractures as well as the rock matrix. Flowpaths in the rock matrix tended to spread further from each other with increasing distance from the well, whereas flowpaths in fractures tended to remain in the fractures.

The effects of pumping were simulated to illustrate the changes in the sources and direction of ground-water flow that might prevail at low pumping rates. A total of $2 \mathrm{gal} / \mathrm{min}$ was pumped from the same two fissile zones as previously discussed. One-half the amount was pumped from each zone. A total of $2 \mathrm{gal} / \mathrm{min}$ was added to the lateral inflow at the boundaries of the model grid, distributed among the cells in proportion to the lateral inflow under nonpumping conditions so that a mass balance was maintained. The simulated rate of pumping was sufficient to capture particles that, under nonpumping conditions, flowed downgradient and discharged from the modeled area (fig. 30A and $30 \mathrm{C})$. The source of flow changed significantly to the east in both flow zones. Flow in the lower zone was complex (fig. 30A and 30C); flow was mainly in the fractures, as opposed to in the rock matrix, with a short-circuiting of flow by a high-angle fracture. This is similar to what was observed during the aquifer test at CS-221.

The flow conditions depicted (figs. 29 and 30) are idealized representations of ground-water flow in the study area. The hydraulic conductivity of the rock matrix could actually be orders of magnitude lower than the value assumed in the simulations, but, because most simulated flow was assigned to fractures, a reduction in the hydraulic conductivity of the rock matrix would not alter the outcome of the simulations. Variations in the distribution of connected fractures and in the size of the openings in the fractures were not simulated, but they also are major factors that affect solute migration. These properties are extremely difficult to measure in the field. This is especially true of the properties of high-angle fractures, which are less frequently intersected by boreholes than are fissile zones because of their near-vertical orientation. The effects of the borehole itself on the flow system were not simulated here, but they may be significant; short circuiting of flow from one fissile zone through the borehole to a lower fissile zone was observed in TH-2 during the aquifer test. Open boreholes affect ground-water flow and solute migration even under nonpumping conditions by providing a conduit for ground-water and (or) solute movement. 


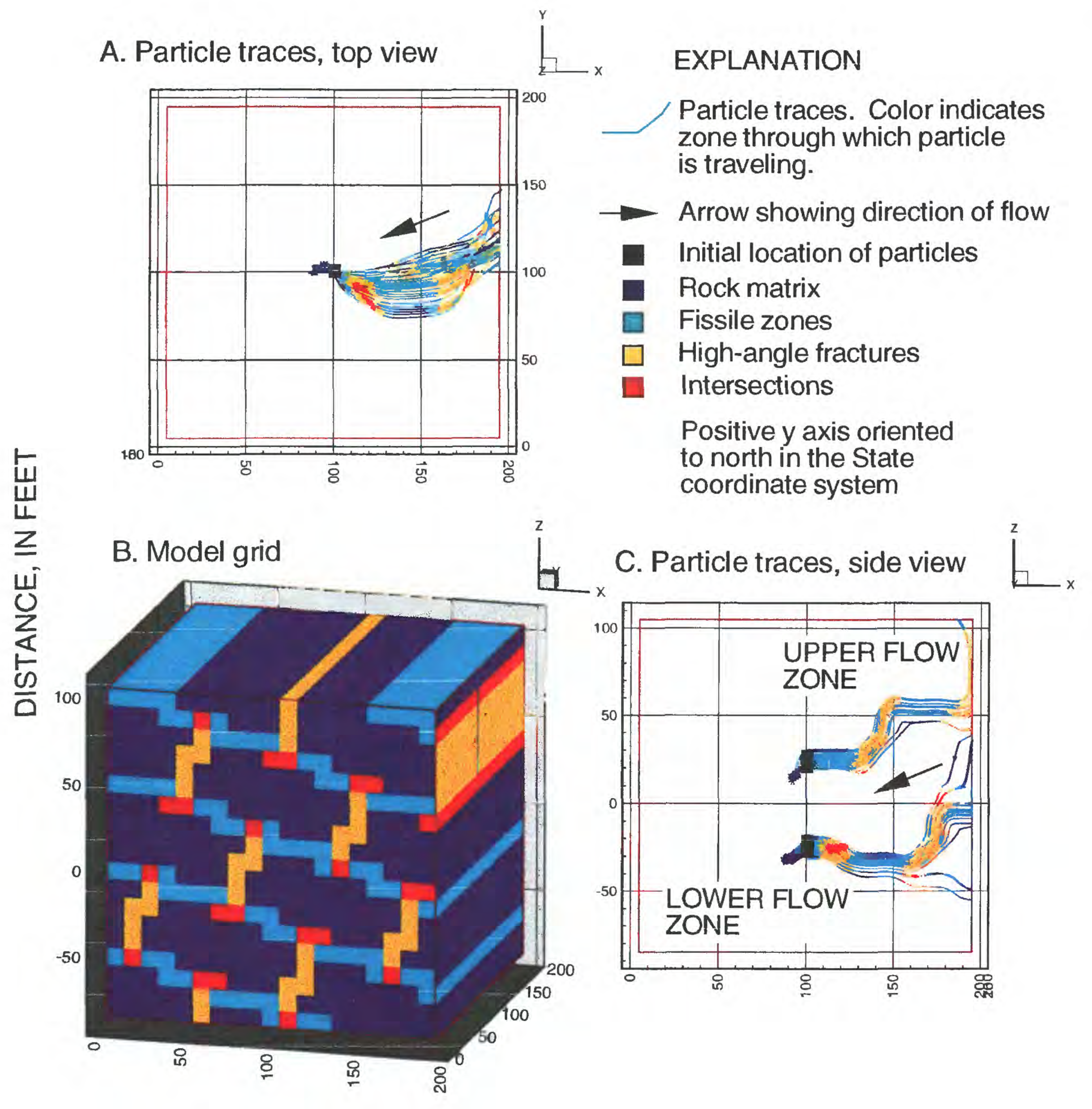

DISTANCE, IN FEET

Figure 30. Particle traces through fractured media under pumping conditions. 


\section{SUMMARY AND CONCLUSIONS}

During 1994-95, an investigation by the USGS, in cooperation with the USEPA, was done in an area in the north-central part of Cheshire, Connecticut. As part of the investigation, the geohydrologic framework of the unconsolidated deposits and sedimentary bedrock was characterized, an understanding of the regional geohydrologic system was integrated with the local geohydrologic conditions, and a conceptual model of ground-water flow was developed.

Ground-water quality in the study area has been degraded by volatile organic contaminants at two industrial sites and at a single-family residence. The site at and around $604 \mathrm{~W}$. Johnson Ave. is on the USEPA Superfund list; contaminants found in ground water since 1983 at this site include TCA, methylene chloride, DCA, 1,1-DCE, PCE, heptane, and acetone, as well as hydrocarbon contamination tentatively identified as No. 2 fuel oil. At a second site at 30 Knotter Dr., similar contaminants were found, as well as TCE, chloroform, DCE, and 1,2-DCE. At the single-family residence (well CS-221), contaminants have been documented since 1983 and include TCA, PCE, TCE, DCE, DCA, ethylbenzene, benzene, toluene, o-xylene, $\mathrm{m}$ xylene, and chloroform. Levels of contamination at CS-221 seem to have declined since sampling in 1984-88. Low levels $(1 \mu \mathrm{g} / \mathrm{L})$ of contamination were present in CS-221 and in shallow wells SW-1 and SW-2 at 604 W. Johnson Ave. There was no detection of contaminants during this investigation in deep bedrock wells located $90 \mathrm{ft}$ to the north and $130 \mathrm{ft}$ to the south of CS-221. Contaminated ground water that exceeds State and Federal maximum contaminant levels for drinking water was present in 1995 at the second industrial site.

The regional area is in the drainage basin of the Quinnipiac River-a major river that flows southward within a broad, north-south trending lowland. The area is located near the western border of the Central Lowland of Connecticut (also known as the Hartford Basin) and is underlain by sedimentary and (locally) igneous rocks of Mesozoic age. The most extensive bedrock in the regional area is eastward-dipping fluvial redbeds (siltstone, sandstone, and conglomerate) of the New Haven Arkose (Late Triassic). All bedrock in the regional study area is extensively fractured; fractures are the sig- nificant pathways for ground-water flow in the bedrock. Unconsolidated materials overlying bedrock in the area are predominantly glacial sediments (till and stratified deposits) laid down during advance and retreat of the last (late Wisconsinan) ice sheet.

The Cheshire study area is in the Judd Brook drainage basin. Judd Brook is tributary to the Tenmile River, which in turn is a tributary to the Quinnipiac River. Topographically, the eastern part of the study area is a low north-south trending hill; the area slopes westward to lower-lying, relatively flat surfaces along Judd Brook. Unconsolidated materials consist predominantly of fine sand, silt, and clay of glaciolacustrine origin, and locally till, that range from a few to more than $25 \mathrm{ft}$ in thickness. Finegrained stratified deposits beneath the Judd Brook valley are up to $100 \mathrm{ft}$ thick. Bedrock in the Cheshire study area is lower New Haven Arkose; rock units strike northward and dip eastward at about $20^{\circ}$. The redbeds in the area consist of two basic rock types: (1) channel sandstone units, which are coarse sandstone to fine conglomerate, generally 6 to $15 \mathrm{ft}$ thick; and (2) overbank mudstone units, which are siltstone and silty sandstone with some fine sandstone, generally 6 to $50 \mathrm{ft}$ thick. Thin-bedded zones of siltstone that are particularly fissile occur locally within the mudstone units. The eastward-dipping strata are cut by a consistent set of west to west-northwest dipping, high-angle fractures. These fractures are oriented perpendicular to bedding and are present mostly in the channel sandstone units, but locally extend into mudstone units as well. Heat-pulse flowmeter measurements and borehole fluid-conductivity and temperature logs indicate that only a small number of bedding-planeparallel fissile zones and some high-angle fractures are hydraulically significant. Results of a squarearray resistivity sounding yielded an estimated fracture porosity in the bedrock of 0.02 , with a standard deviation of 0.003 .

Precipitation is the primary source of recharge to ground water in the Quinnipiac River basin, and mean annual precipitation in the basin is about 47 in. During this investigation, precipitation caused water levels to rise quickly in monitored wells that tap unconsolidated materials and fractured bedrock. Water-level data also indicate good hydraulic connection between the unconsolidated materials and underlying fractured rock. In general, 
the range in ground-water levels was larger in the fractured bedrock than in the unconsolidated materials. These larger fluctuations result in part from a lower storage capacity of the fractured bedrock than that of the unconsolidated materials. Synoptic water-level measurements made in June 1995 indicate that the hydraulic gradient near the water table slopes predominantly from a low hill on the eastern side west and southwest toward a pond and wetlands along Judd Brook. The direction of flow near CS-221 is west-southwest, and the recharge area to CS-221 (at the time of measurement) is east-northeast of the well.

Several short-duration aquifer tests were done to gain an understanding of the hydraulic properties and response of the fractured-bedrock system to pumping at CS-221 (at rates of 2 and $4 \mathrm{gal} / \mathrm{min}$ ). The results of these tests indicate good hydraulic connection between CS-221 and two bedrock wells located along bedding strike $90 \mathrm{ft}$ to the north and $130 \mathrm{ft}$ to the south. Observation wells located transverse to the strike of bedding did not respond to pumping during the timeframe of the aquifer tests (200 and 270 minutes). A response was not likely because these wells do not intersect the same water-bearing zones as the pumped well, and one well was located $430 \mathrm{ft}$ from the pumped well. A range of transmissivity of 27 to $46 \mathrm{ft}^{2} / \mathrm{d}$ for the fractured-bedrock aquifer system was calculated from the aquifer tests.

A numerical ground-water-flow model of the regional study area developed during the investigation indicates that perennial streams within the region, including Judd Brook and the Tenmile River, form hydrologic divides that separate the larger region into hydraulically independent flow systems - that is, ground-water flowpaths do not extend across perennial streams. The regional model was also used to determine the direction and average linear velocity of ground-water flow in the local study area. In a cell representing a 250 -by- 250 $\mathrm{ft}$ area of the regional model containing CS-221, the direction of ground-water flow was S. $42^{\circ} \mathrm{W}$. and the velocity of flow was $0.4 \mathrm{ft} / \mathrm{d}$.

A conceptual model of ground-water flow was developed for the study area. The bedrockaquifer system consists of alternating beds of fineand coarse-grained rock. Ground water flows in the fine-grained rock units in fissile zones that are par- allel to bedding, and between fissile zones ir highangle fractures that are perpendicular to bedding. The result is an aquifer system in which ground water follows a stair-step flowpath, flowing, horizontally through fissile zones and vertically th rough high-angle fractures. A generalized local-scale ground-water flow simulation for a 200-by-200-by 200 -ft cube surrounding CS-221 included a nonspecific but realistic pattern of rock and fracture geometry as determined from geologic and geopt '/sical investigation and general characteristics of f'ow as determined from aquifer tests done in the stucy area and regional model simulation. In the simulation, ground water flowed in upper and lower zones where flowpaths differed but generally were from northeast to southwest; flow occurred predominantly in fracture sets (as opposed to the rock matrix) and some flow was short-circuited by highangle fractures. Flow in the high-angle fractures was more southerly than the flow in the fissile zones.

Several conclusions concerning groundwater flow in the Cheshire study area can be drawn from the data that were collected and the conceptual model developed during this investigation:

(1) The flow of ground water from the study area to public supply wells at the North Cheshire Well Field is extremely unlikely under any possible conditions. The stratified-drift aquifers in this area discharge to streams that separate ground-water flow at the North Cheshire Well Field and the Cheshire study area.

(2) Ground water in the study area flow: preferentially in discrete fracture zones, which have a predominant north-south orientation. The calculated range of transmissivity of the fractured bedrock is 27 to $46 \mathrm{ft}^{2} / \mathrm{d}$; because individual waterbearing fractures zones are thin, hydraulic conductivities are potentially as high as $92 \mathrm{ft} / \mathrm{d}$.

(3) The natural head gradient in the study area slopes westward to southwestward. North-southtrending fractures provide preferential pathways for ground-water flow. The ground-water flow-direction lies between the direction of the gradient and the orientation of preferred pathways. Therefore, the probable source area of ground-water flow to the domestic well CS-221 ranges from north to east under low-pumping rate conditions. Low pumping rates were used in the aquifer tests and local-scale 
model simulation and also are presumed to have existed during the time the well was used for domestic-water supply.

(4) Ground water at $604 \mathrm{~W}$. Johnson Ave. flows westward and discharges to the ponds located on the property. Contamination in the overburden at this site is likely to have moved westward over time. If contamination entered fractured bedrock at this site, it may have entered ground water that flowed to the domestic well (CS-221) during the time the well was in use, because fracture zones at the two sites are connected hydraulically. However, no contamination was found during this investigation in two bedrock wells installed on the property at $604 \mathrm{~W}$. Johnson Ave.

(5) This study illustrates the complexity of ground-water flow in fractured rock. In particular, it shows that an open borehole is not an optimum sampling point because water from many different zones may be combined, and that, under pumping conditions, the relative proportions of water from each zone may change. The testing done for this study indicates that ground water flows in discrete zones and that these zones are not confined to single fissile zones; thus, solutes may migrate across bedding through high-angle fractures. The hydraulic connection of fractures from one well to another cannot be determined solely from geologic analysis because not all geologic features are hydraulically significant. If ground-water flow occurs in discrete zones, as simulated in this study, the directions of flow can be different in each zone; it is not possible to determine flow directions solely from hydraulic heads that are measured in each individual fracture. To determine flow directions on the basis of hydraulic heads, a complete knowledge of the spatial distribution of hydraulic conductivity is necessary. Because this knowledge is nearly impossible to obtain, a distinct chemical signature or artificially introduced tracer may be the only way to determine the direction of ground-water flow in these rocks. 


\section{SELECTED REFERENCES}

ALTA Environmental Corporation, 1994a, Summary of groundwater monitoring results Holgrath Medical Technologies facility, Cheshire, Conn. (October 1994): Marlborough, Conn., 4 p., 2 appendixes (A-B).

ALTA Environmental Corporation, 1994b, Technical memorandum-summary of recent remedial investigation work Holgrath Medical Technologies facility, Cheshire, Connecticut (November 1994): Marlborough, Conn., 8 p., 7 appendixes (A-G).

ALTA Environmental Corporation, 1995, Summary of groundwater monitoring results Holgrath Medical Technologies facility, Cheshire, Conn. (May 1995): Marlborough, Conn., 4 p., 2 appendixes (A-B).

Amtec Engineering, Inc., 1994, Tecplot Version 6.0 User's Manual, 2d ed., July 1994: Bellevue Washington, Amtec Engineering, Inc., variously paginated.

Anderson, M.P. and Woessner, W.W., 1992, Applied Groundwater Modeling: San Diego, Academic Press, $351 \mathrm{p}$.

Barlow, P.M., 1994, Particle-tracking analysis of contributing areas of public-supply wells in simple and complex flow systems, Cape Cod, Massachusetts: U.S. Geological Survey Open-File Report 93-159, 68 p.

Buchanan, T.J., and Somers, W.P., 1969, Discharge measurements at gaging stations: U.S. Geological Survey Techniques of Water-Resources Investigations, book 3, chap. A8, 65 p.

Carter, R.W., and Davidian, Jacob, 1968, General procedures for gaging streams: U.S. Geological Survey Techniques of Water-Resources Investigations, book 3, chap. A6, 13 p.

Chesprocott Health District, 1985, Chesprocott Health District water supply study: Cheshire, Conn., $17 \mathrm{p}$.

Driscoll, F.G. (principal author and editor), 1986, Groundwater and wells (2d ed.): St. Paul, Minn., Johnson Filtration Systems Inc., 1089 p.
EEW Management, Inc., 1994, Geoprobe investigation results Philips Technologies Inc., Cheshire, Conn. (March 1994): Torrington, Conn., 9 p., 5 appendixes (A-E).

Freeze, R.A., and Cherry, J.A., 1979, Groundwater: Englewood Cliffs, New Jersey, Prentize-Hall Inc., $604 \mathrm{p}$.

Fritts, C.E., 1963, Bedrock geology of the Southington quadrangle, Connecticut: U.S. Geological Survey Map GQ-200, scale 1:24,000.

Ground Water Associates, Inc., 1980, Rejort to General Electric on ground-water quality at a site in Cheshire, Connecticut: 17 p., 2 appendixes $(A-B)$.

Haeni, F.P., and Anderson, H.R., 1980, Hydrogeologic data for south-central Connecticut: Connecticut Water Resources Bulletin 32, 43 p.

Haley and Aldrich, Inc., 1993, Environmental site assessment report, the Holgrath Corporation, Cheshire, Connecticut: Glastonbury, Conn., 48 p., 10 appendixes (A-J).

Hanshaw, P.M., 1962, The surficial geology of the Meriden quadrangle, Connecticut: U.S. Geological Survey Geologic Quadrangle Map G?-150, scale $1: 24,000$.

Hanshaw, P.M., 1968, Bedrock geologic map of the Meriden quadrangle, New Haven, Hartfo'd, and Middlesex Counties, Connecticut: U.S. Geological Survey Geologic Quadrangle Map G?-738, scale $1: 24,000$.

Hearst, J.R., and Nelson, P.H., 1985, Well logging for physical properties: New York, McGrawHill Book Co., 576 p.

HRP Associates, Inc., 1987, Report on work performed to date Holgrath Corporation, Cheshire, Connecticut: New Britain, Conn., 18 p., 10 appendixes (A-J).

Hubert, J.F., Feshbach-Meriney, P.E., and Smith, M.A., 1992, The Triassic-Jurassic Hartford rift basin, Connecticut and Massachusetts-Evolution, sandstone diagenesis, and hydrocarbon history: American Association of Petroleum Geologists Bulletin, v. 76, no. 11, p. 1710-1734. 
Hubert, J.F., Reed, A.A., Dowdall, W.L., and Gilchrist, J.M., 1978, Guide to the redbeds of central Connecticut, in 1978 fieldtrip, eastern section of the Society of Economic Paleontologists and Mineralogists: Amherst, Mass., University of Massachusetts Department of Geology and Geography Contribution 32,129 p.

Keys, W.S., 1990, Borehole geophysics applied to ground-water investigations: U.S. Geological Survey Techniques of Water-Resources Investigations, book 2, chap. E2, 150 p.

Kruseman, G.P., and deRidder, N.A., 1991, Analysis and evaluation of pumping test data ( $2 \mathrm{~d}$ ed.), in International Institute for Land Reclamation and Improvement Publication 47: The Netherlands, Wageningen, $377 \mathrm{p}$.

Lane, J.W., Jr., Haeni, F.P., and Watson, W.M., 1995, Use of a square-array direct-current resistivity method to detect fractures in crystalline bedrock in New Hampshire: Ground Water, v. 33 , no. 3, p. 476-485.

LaSala, A.M., Jr., 1961, Surficial geology of the Southington quadrangle, Connecticut: U.S. Geological Survey Map GQ-146, scale $1: 24,000$.

Leggette, Brashears, and Graham, Inc., 1992, South Central Connecticut Regional Water Authority, Data collection plan for level A mapping of North Cheshire well field: Wilton, Conn.

Mazzaferro, D.L., 1973, Hydrogeologic data for the Quinnipiac River basin, Connecticut: Connecticut Water Resources Bulletin 26, 54 p.

----1975, Contour map of the bedrock surface, Southington quadrangle, Connecticut: U.S. Geological Survey Miscellaneous Field Studies Map MF-660-A, scale 1:24,000.

Mazzaferro, D.L., Handman, E.H., and Thomas, M.P., 1979, Water resources inventory of Connecticut, part 8, Quinnipiac River basin: Connecticut Water Resources Bulletin 27, 88 p.

McDonald, M.G., and Harbaugh, A.W., 1988, A modular three-dimensional finite-difference ground-water flow model: U.S. Geological Survey Techniques of Water-Resources Investigations, book 6 , chapter A1, unpaginated.
McInerney, Dennis, 1993, Fluvial architecture and contrasting fluvial styles of the lower New Haven Arkose and the mid-upper Portland Formation, early Mesozoic Hartford Basin central Connecticut: Amherst, Mass., Unive-sity of Massachusetts, unpublished Masters thesis, $271 \mathrm{p}$.

Melvin, R.L., de Lima, Virginia, and Stone, B.D., 1992a, The stratigraphy and hydraulic properties of tills in southern New England: U.S. Geological Survey Open-File Report 91-481, 53 p.

Melvin, R.L., Stone, B.D., Stone, J.R., and Trask, N.J., 1992b, Hydrogeology of thick till deposits in Connecticut: U.S. Geological Surve"' OpenFile Report 92-43, 43 p.

Melvin, R.L., Stone, J.R., Craft, P.A., Lare, J.W., Jr., and Davies, B.S., 1995, Geohydrology and water quality of the Durham Center area, Durham, Connecticut: U.S. Geological Survey Water-Resources Investigations Report 94-4237, 97 p.

Metcalf and Eddy, Inc., 1993, Draft data summary report, Start initiative, Cheshire Associatos property, Cheshire, Connecticut: 105 p., 11 appendixes $(\mathrm{A}-\mathrm{K})$.

Morin, R. H., Carleton, G. B., and Poirier, Stephane, in press, Hydrogeologic structure of a fractured sedimentary-rock aquifer as determined from geophysical log analysis, Passaic Formation, central New Jersey: 5th International Symposium of the Minerals and Geotechnical Logging Society, Santa Fe, New Mexic’, October 1995 .

NUS Corporation, 1986a, Cheshire Associates Property final site inspection report: Pedford, Mass., 18 p.

NUS Corporation, 1986b, Airpax Corporation final site inspection report: Bedford, Mass., 17 p.

NUS Corporation, 1989; Final screening site inspection letter report, Superior Steel Products Corporation, Cheshire, Connecticut: Pedford, Mass., 15 p.

NUS Corporation, 1990, Final screening site inspection TRW DOT Fastener $\Gamma$ :vision, Cheshire, Connecticut: Bedford, Mass., 13 p.. 3 attachments (A-C). 
Pollock, D.W., 1994, User's Guide for MODPATH/MODPATH-PLOT, Version 3-A particle tracking post-processing package for MODFLOW, the U.S. Geological Survey finitedifference ground-water flow model: U.S. Geological Survey Open-File Report 94-464, variously paginated.

Randall, A.D., Francis, R.M., Frimpter, M.H., and Emery, J.M., 1988, Region 19, Northeastern Appalachians, in Back, William, Rosenshein, J.S., and Seaber, P.R., eds., Hydrogeology: Boulder Colorado, Geological Society of America, The Geology of North America, v. O-2, p. $177-187$.

Rantz, S.E., 1982, Measurement and computation of streamflow-volume 1. Measurement of stage and discharge: U.S. Geological Survey Water-Supply Paper 2175, 284 p.

Rodgers, John, compiler, 1985, Bedrock geological map of Connecticut: Connecticut Geological and Natural History Survey, Natural Resources Atlas Series Map, 2 sheets, scale 1:125,000.

Roy F. Weston, Inc., 1990, Removal program preliminary assessment/site investigation for TRW DOT Fastener facility site, Cheshire, Connecticut: Westborough, Mass., 6 p., 7 Attachments $(A-G)$.

Stephenson, D.A., Fleming, A.H., and Mickelson, D.M., 1988, Glacial deposits, in Back, William, Rosenshein, J.S., and Seaber, P.R., eds., Hydrogeology: Boulder Colorado, Geological Society of America, The Geology of North America, v. O-2, p. 301-314.
Stone, J.R., Schafer, J.P., London, E.H., and Thompson, W.B., 1992, Surficial materia's map of Connecticut: U.S. Geological Survey S pecial Map, 2 sheets, scale 1:125,000.

Stone, J.R., Stone, B.D., and Lewis, R.S., 1985, Late Quaternary deposits of the southern Quinnipiac-Farmington lowland and Long Island Sound basin-their place in a regional stratigraphic framework, in Tracy, R.J., ed., New England Intercollegiate Geological Conference, 77th annual meeting, New Haven, Conn., October 4-6, 1985, Guidebook for field trips ir Connecticut and adjacent areas of New York and Rhode Island: Connecticut Geological and Natural History Survey Guidebook 6, p. 535-575.

Theis, C.V., 1935, The relation between the lowering of the piezometric surface and the $\mathrm{ra}^{+} \mathrm{e}$ and duration of discharge of a well using groundwater storage: American Geophysical Union Transactions, v. 16, p. 519-524.

U.S. Environmental Protection Agency, 1992, Superfund: Progress at National Priorit:' List Sites, Connecticut 1992 Update: U.S. Environmental Protection Agency EPA/540/R-93/007, $35 \mathrm{p}$.

Vecchioli, John, Carswell, L.D., and Kasabach, H.F., 1969, Occurrence and movement of ground water in the Brunswick Shale at a site near Trenton, New Jersey: U.S. Geological Survey Professional Paper 650-B, p. B154-B157.

Williams, J.H., and Conger, R.W., 1990, Preliminary delineation of contaminated water-bearing fractures intersected by open-hole bedrock wells: Ground Water Monitoring Review, v. 10, no. 4, p. $118-126$. 


\section{GLOSSARY}

Aquifer Test-A test to determine hydrologic properties of the aquifer involving the withdrawal of measured quantities of water from or addition of water to a well and the measurement of resulting changes in head in the aquifer both during and after the period of discharge or additions.

Arkose (lithic arkose) — A feldspar-rich sandstone, typically coarse-grained and pink or reddish, that is composed of angular to subangular grains that may be either poorly or moderately well sorted and is usually derived from the rapid disintegration of granite or granitic rocks.

Artesian Aquifer-An aquifer bounded above and below by confining units of distinctly lower permeability than that of the aquifer itself.

Bioturbation-The churning and stirring of a sediment by organisms.

Breccia-A coarse-grained clastic rock, composed of angular broken rock fragments held together by a mineral cement or in a fine-grained matrix. It differs from conglomerate in that the fragments have sharp edges and unworn corners.

Caliche-A reddish-brown to buff or white calcareous material of secondary accumulation, commonly found in layers on or near the surface of stony soils or arid and semiarid regions, but also occurring as a subsoil deposit in subhumid climates. It is composed largely of crusts of soluble calcium salts in addition to such materials as gravel, sand, silt, and clay.

Channel Sandstone-Sands and fine gravels deposited in stream beds or other channel that have become lithified into rock.

Diabase-An intrusive rock whose main components are labradorite and pyroxene and which is characterized by ophitic texture. The term corresponds to what is now recognized as diorite.

Drawdown-The vertical distance the water elevation is lowered or the reduction of the pressure head due to the removal of water; also, the decline in potentiometric surface at a point caused by the withdrawal of water from a hydrogeologic unit.
Evapotranspiration-The combined loss of water from a given area by evaporation from the land and transpiration from plants.

Ferroan Calcite-An iron-rich calcite.

Fissile - Capable of being easily split along closely spaced planes.

Glaciolacustrine-Pertaining to, derived from, or deposited in glacial lakes, especially said of the deposits and landforms composed of suspended material brought by meltwater streams flowing into lakes bordering the glacier, such as deltas, kame deltas, and varved sediments.

Head-The height of a vertical column of water whose weight, if of unit cross section, is eaual to the hydrostatic pressure at a given point.

Hydraulic Conductivity - The volume of water that will move through a medium in a unit of time under a unit hydraulic gradient through a unit area measured perpendicular to the direction of flow.

Hydraulic Gradient-A change in the static pressure of ground water, expressed in terms of the height of water above a datum, per unit of distance in a given direction.

Laminae-The thinnest recognizable unit layers of original deposition in a sediment or sedimentary rock, differing from other layers in color, composition, or particle size.

Lodgment Till-A basal till commonly characterized by compact fissile structure and containing stones oriented with their long axes generally parallel to the direction of ice movement.

Overbank Mudstone-Fine-grained sediment (silt, clay, and fine sand), deposited from suspension on a flood plain that cannot be contained within the stream channel, that has become lithified into rock.

Paleosol-A buried soil horizon of the genlogic past.

Porosity-The property of a rock or unconsolidated material of containing voids or open space; it may be expressed quantitatively as the volume of open spaces to total volume of the rock or material. 
Potentiometric Surface-An imaginary surface representing the total head of ground water and defined by the level to which water will rise in a well. The water table is a particular potentiometric surface.

Specific Capacity - The rate of discharge of water from the well divided by the drawdown of the water level within the well.

Storativity-The volume of water an aquifer releases from or takes into storage per unit surface area of the aquifer per unit change in head.

Synoptic Measurements-A group of measurements made simultaneously.

Tholeiitic Basalt-A silica-oversaturated basalt characterized by the presence of low-calcium pyroxenes.
Transmissivity-The rate at which water of the prevailing kinematic viscosity is transmitted through a unit width of the aquifer under a unit hydraulic gradient. More simply, transmissivity is a measure of the ability of an aquifer to transmit water.

Varve-A sedimentary bed or lamina or sequence of laminae deposited in a body of still water within 1 year's time, specifically, a thin pair of graded glaciolacustrine layers seasonal y deposited, usually by meltwater streams, in a glacial lake or other body of still water in front of a glacier. 


\section{APPENDIX 1: Record of inventoried wells and testholes, \\ Cheshire study area, Cheshire, Connecticut}

[See figure 2 for locations] 


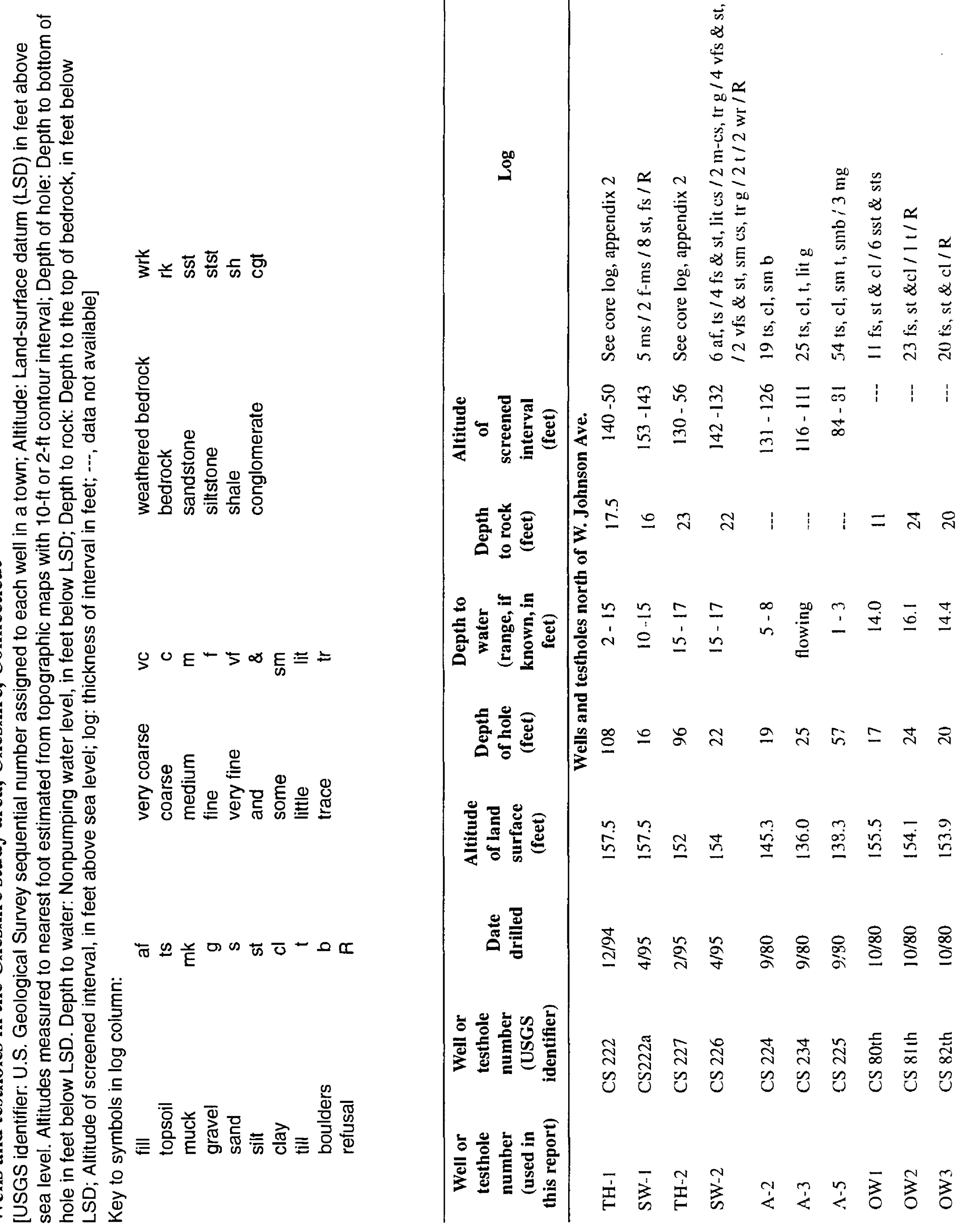




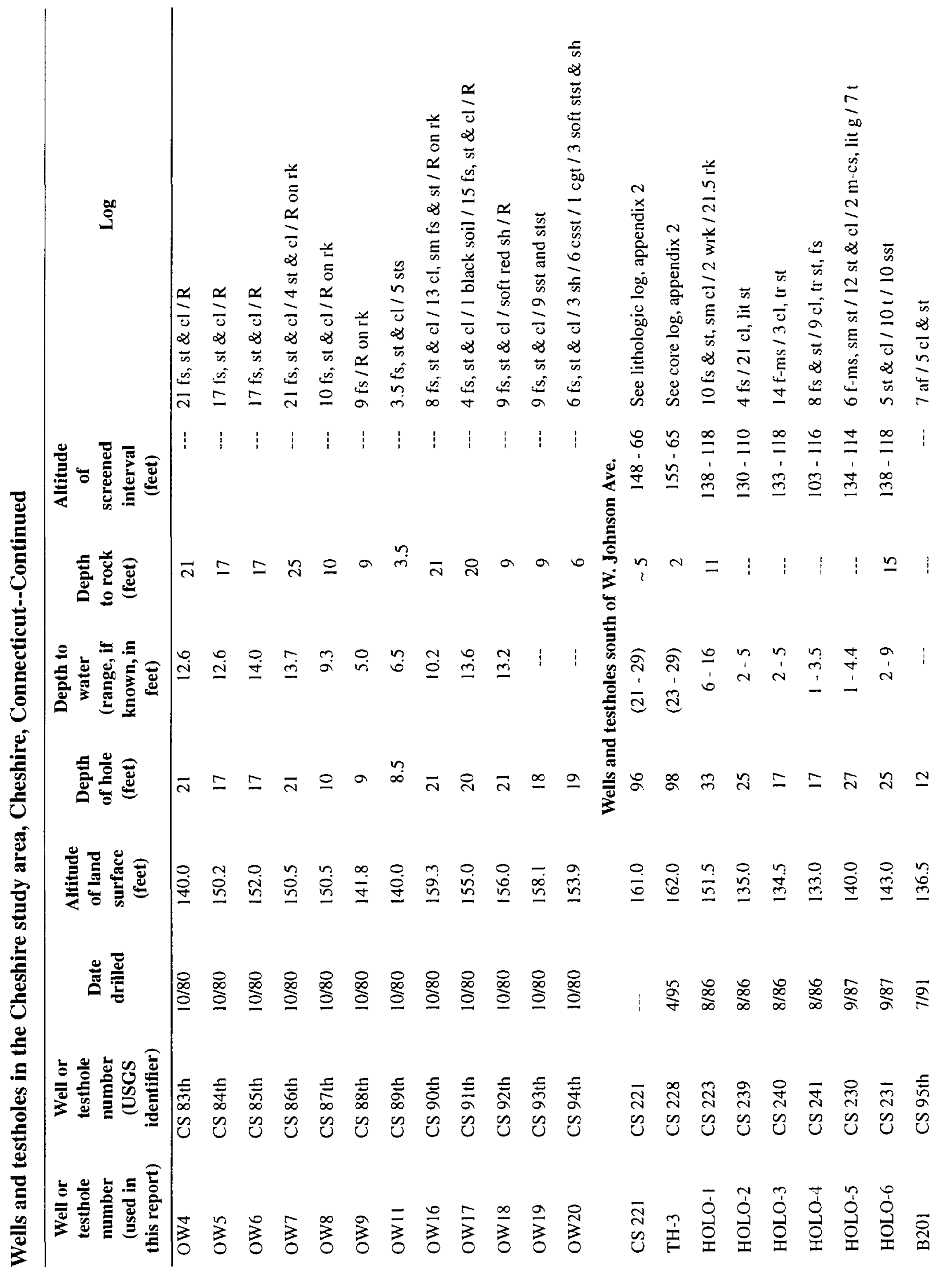




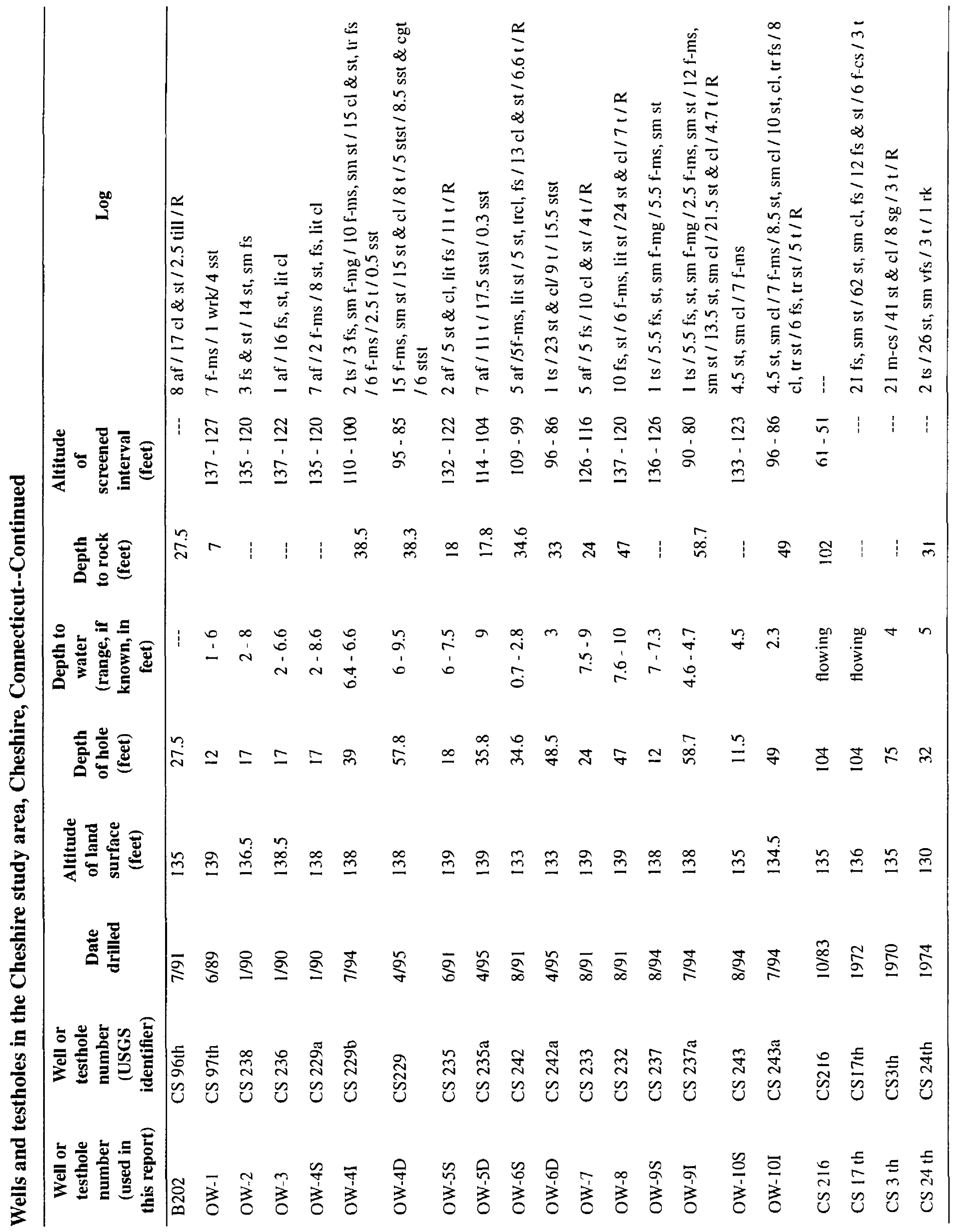

70 Geohydrology and Conceptual Model of a Ground-Water-Flow System Near a Superfund Site in Cheshire, Connecticist 


\section{APPENDIX 2: Record of borehole geophysical and core logs, Cheshire study area, Cheshire, Connecticut}


$\begin{array}{ll}\text { Well name } & \text { CS-221 } \\ \text { Location } & \text { Cheshire }\end{array}$

Altitude TOC 162.17

Date

$12 / 14 / 94$
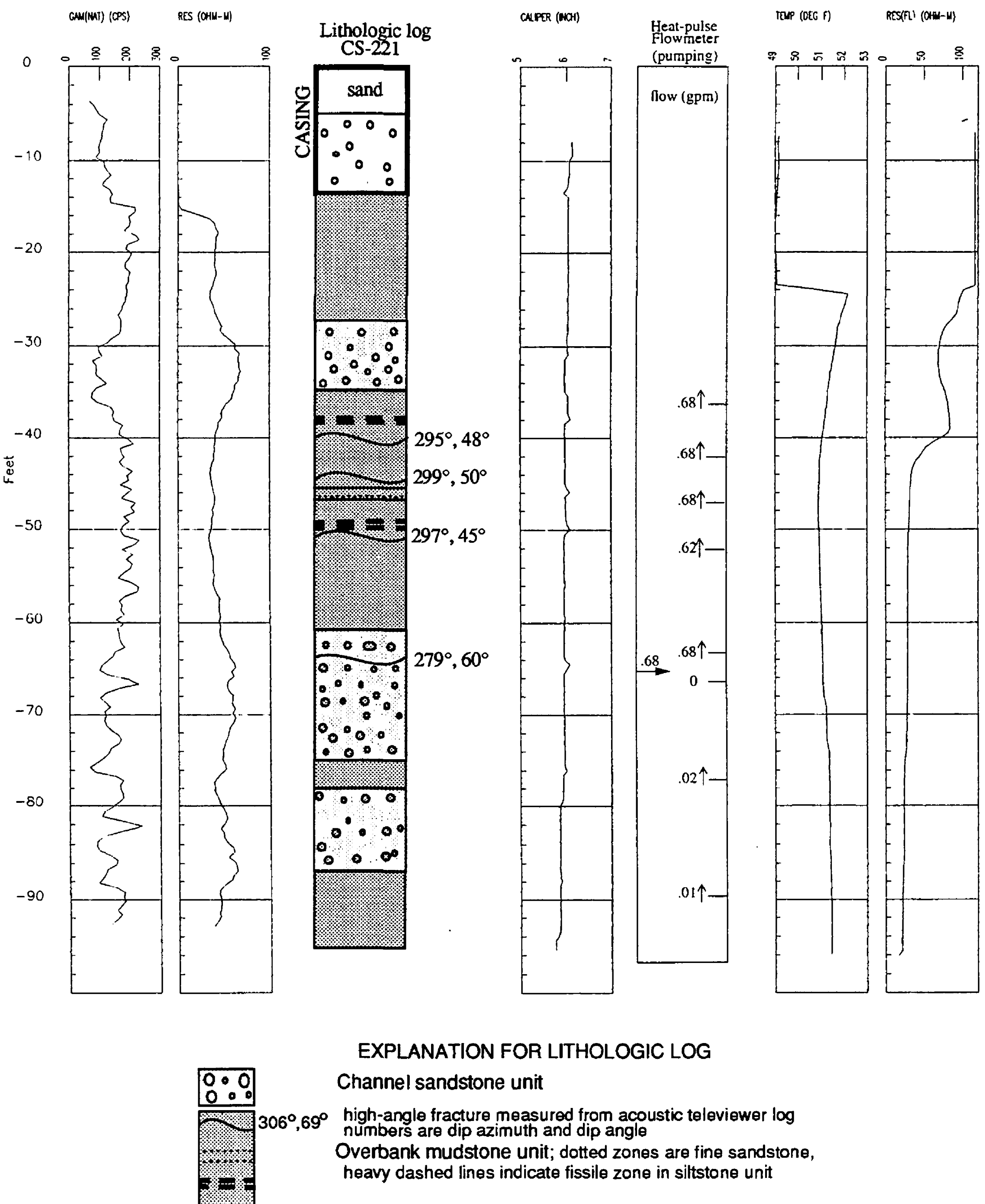


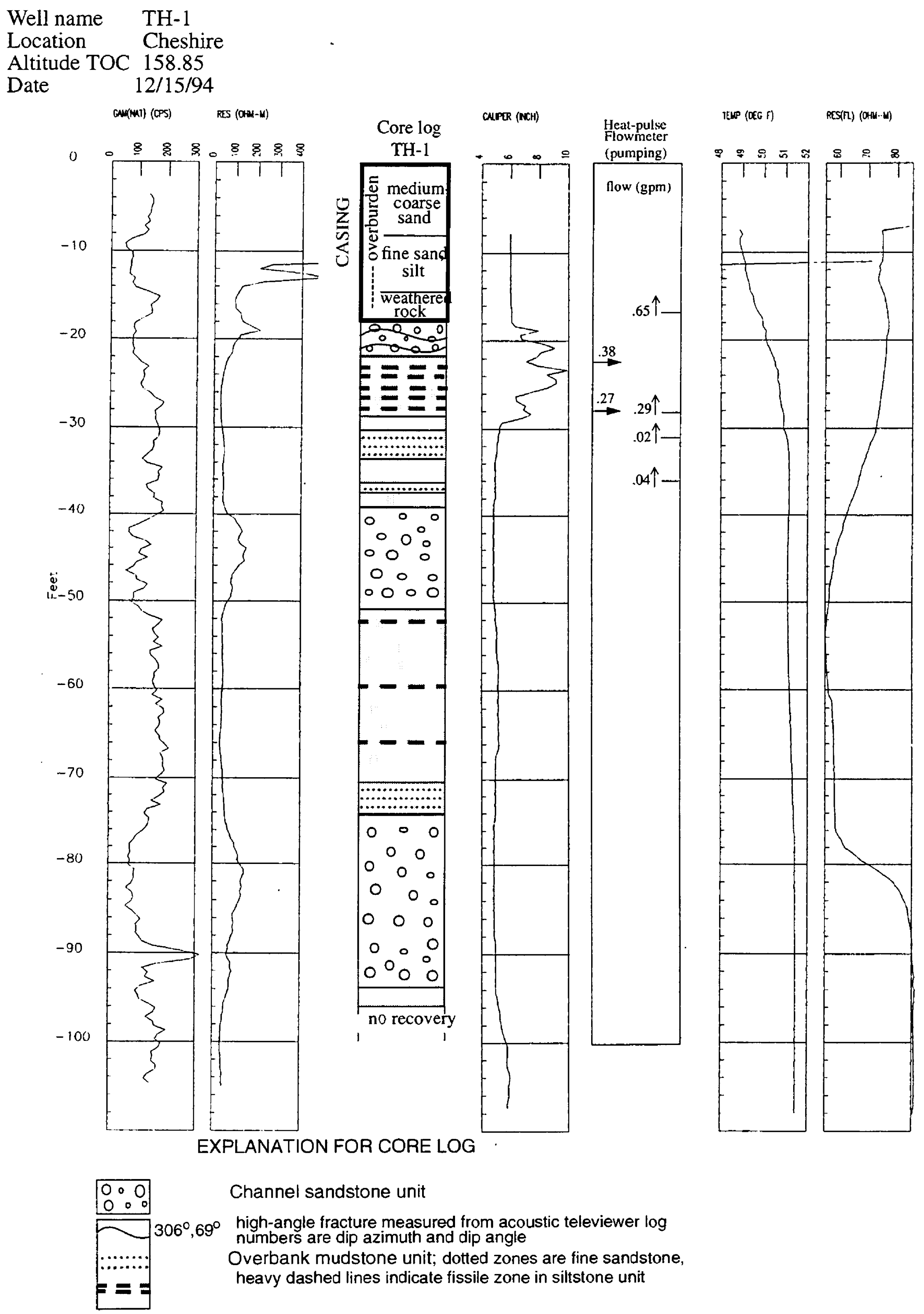


$\begin{array}{ll}\text { Wellname } & \text { TH-2 } \\ \text { Location } & \text { Cheshire } \\ \text { Altitude TOC } & 153.15 \\ \text { Date } \quad 05 / 04 / 95 & \end{array}$

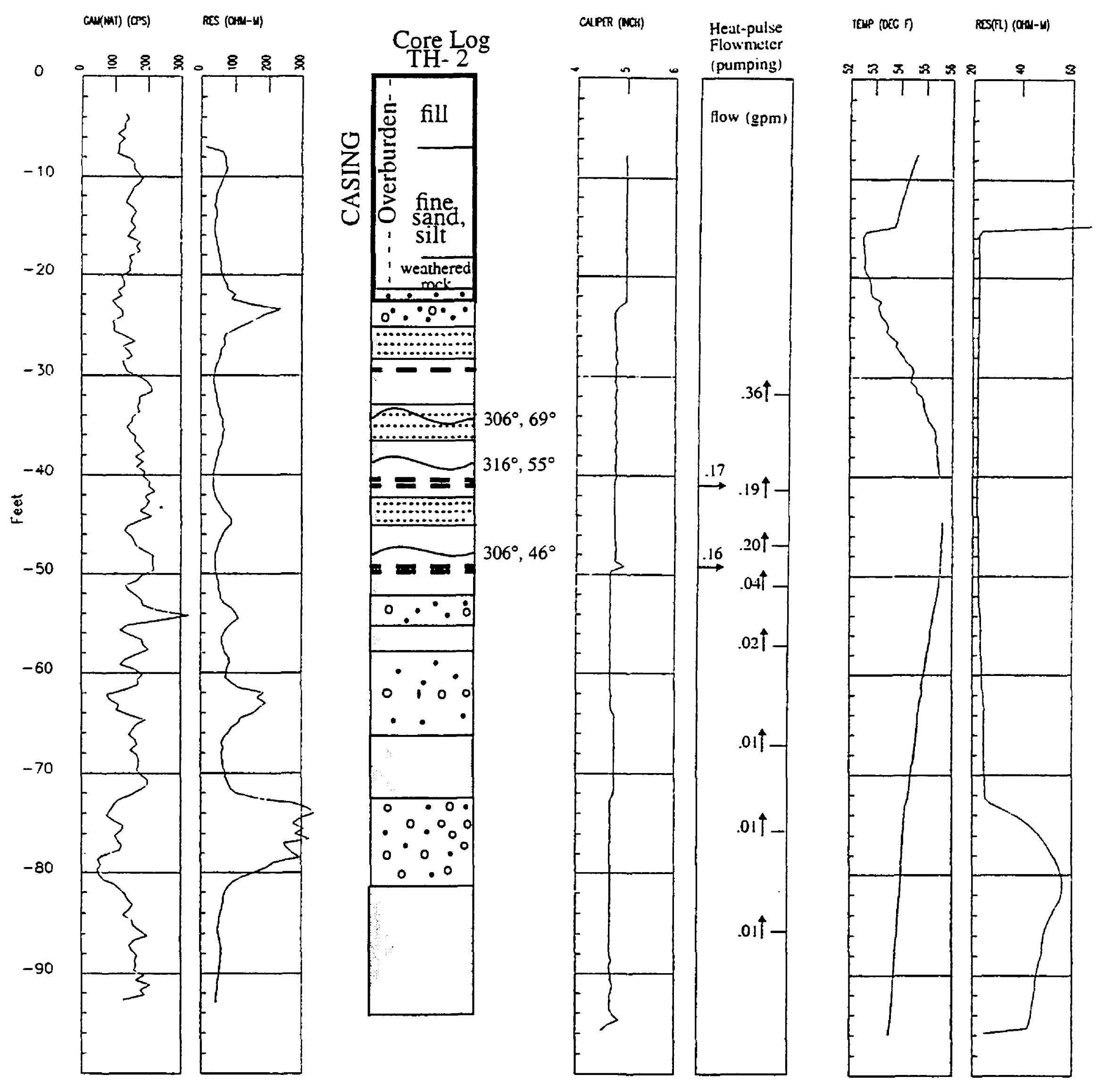

EXPLANATION FOR CORE LOG

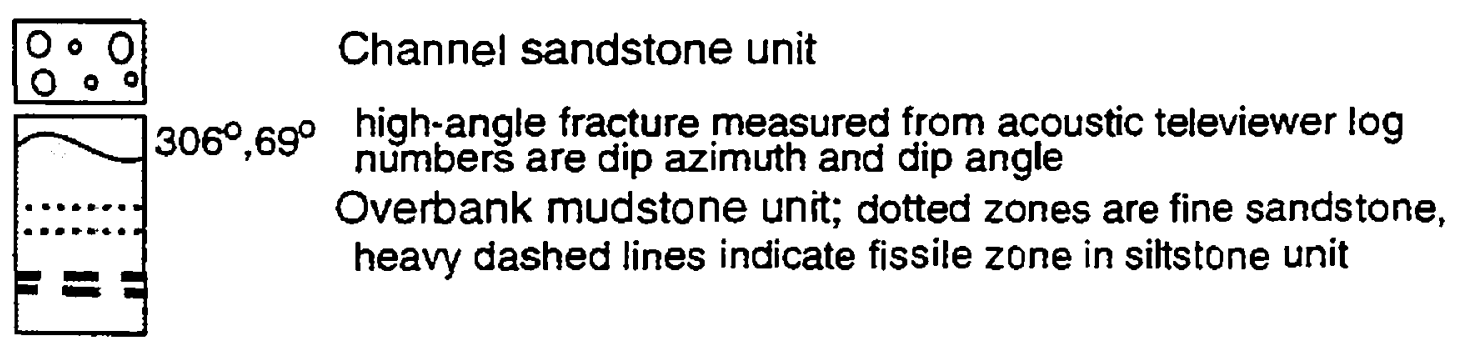


Well name

TH-3

Location Cheshire

Altitude TOC 162.8

Date

$03 / 27 / 95$

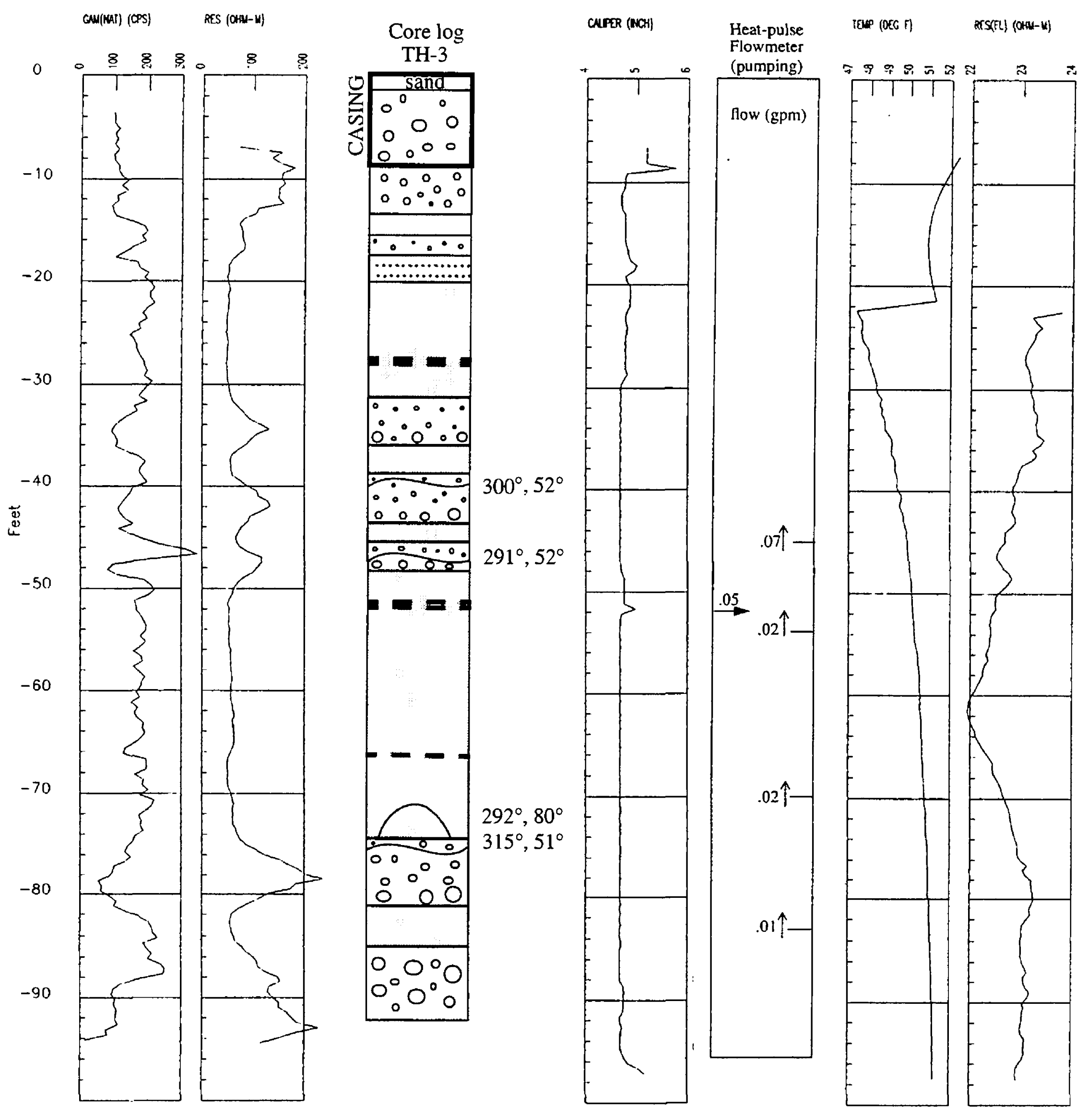

EXPLANATION FOR CORE LOG

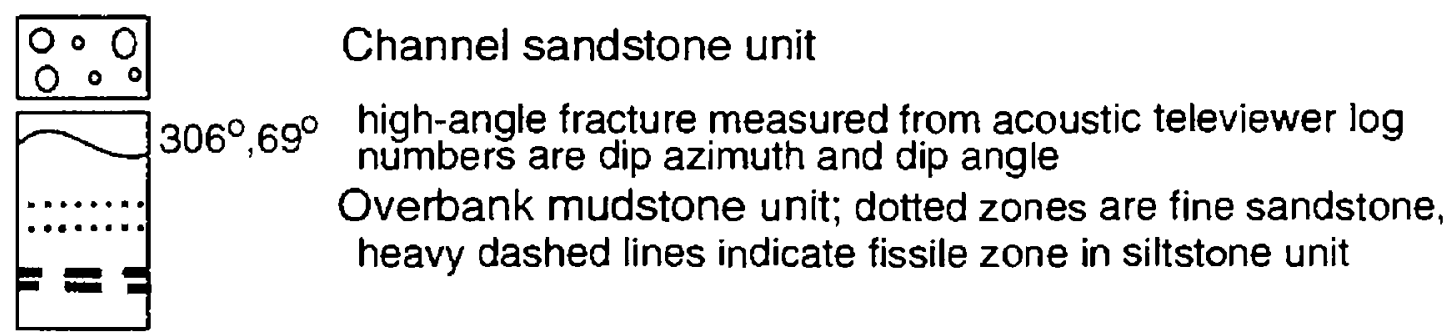


APPENDIX 3: Record of water-level fluctuations at selected wells, Cheshire study area, Cheshire, Connecticut 


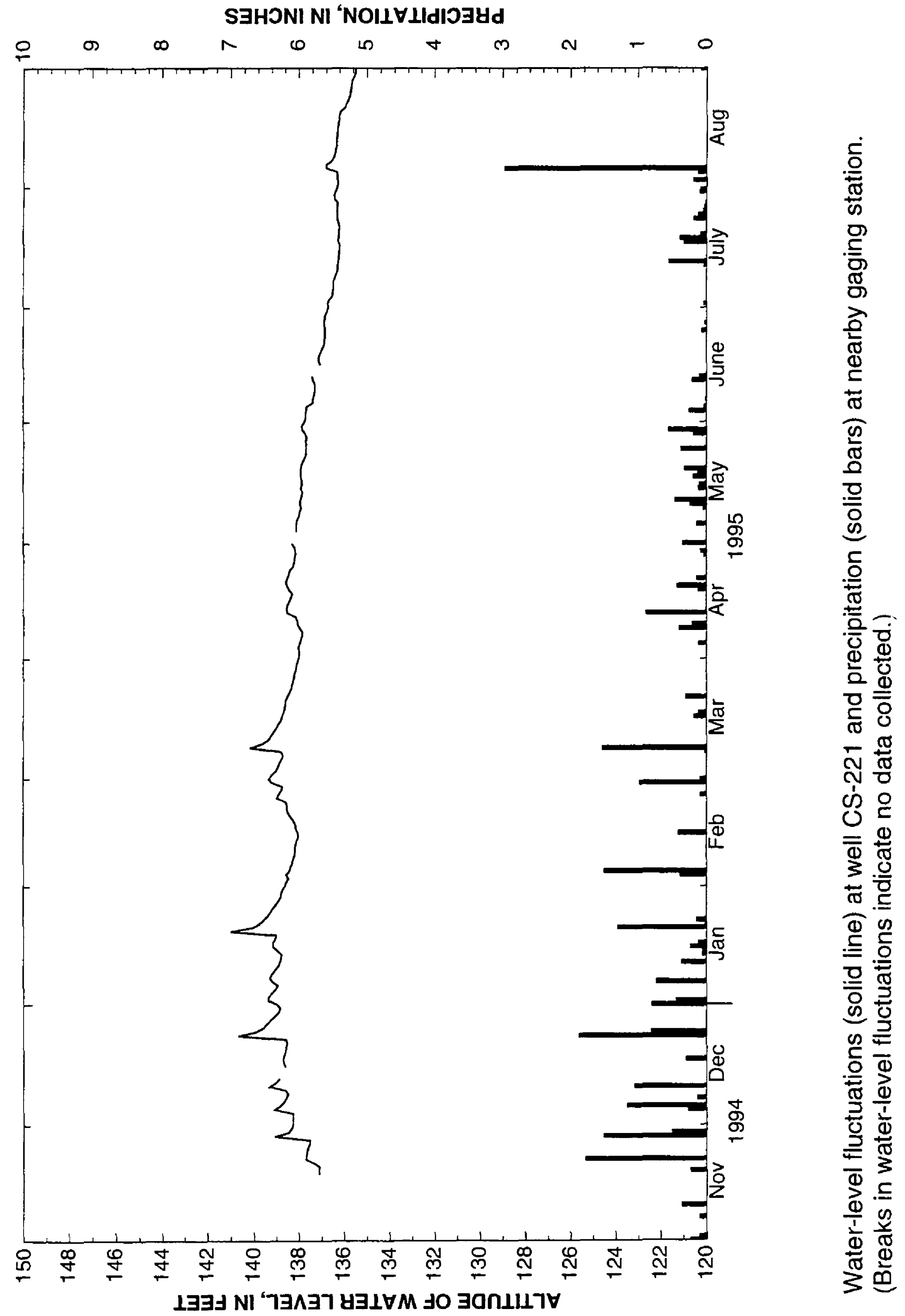




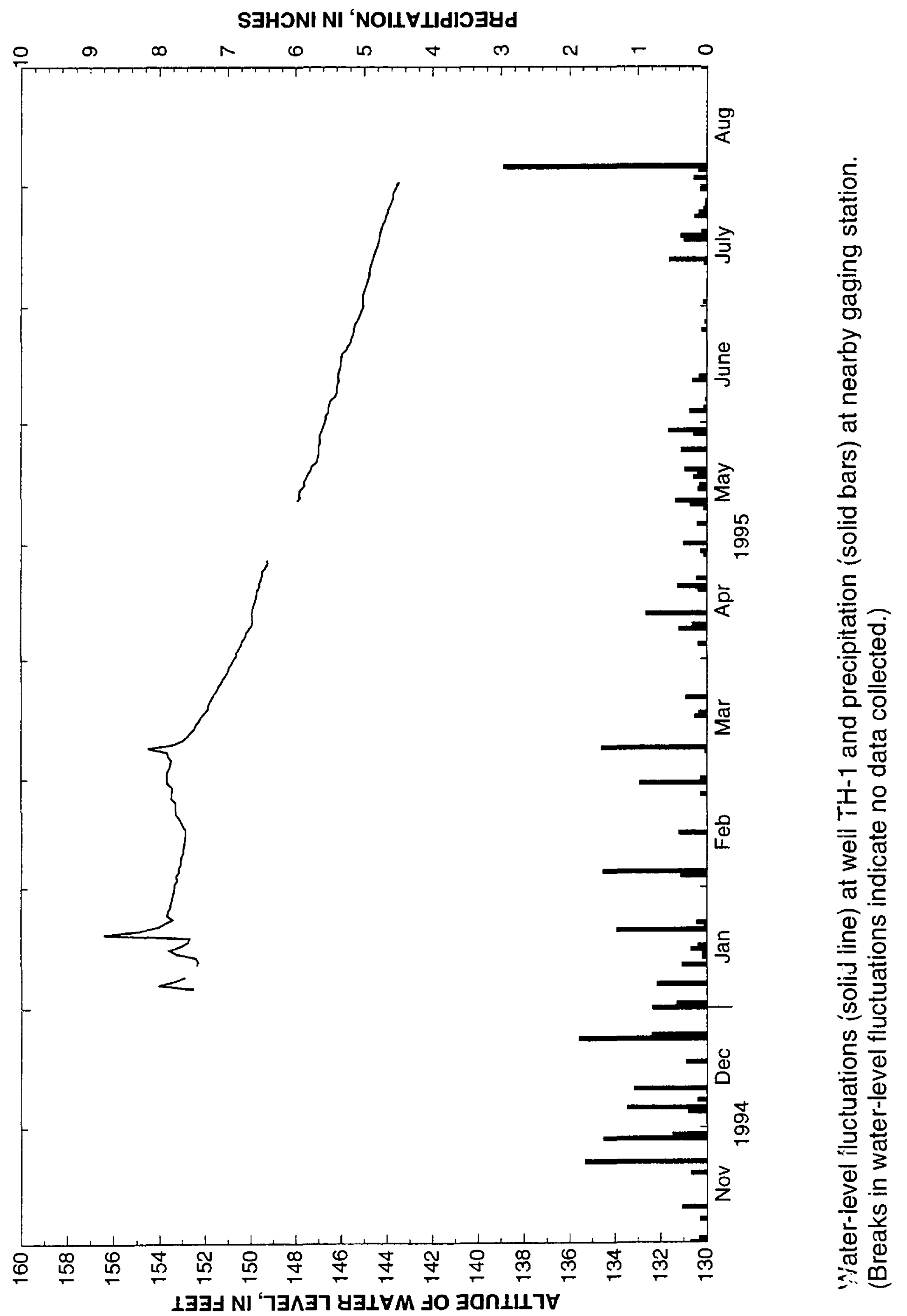




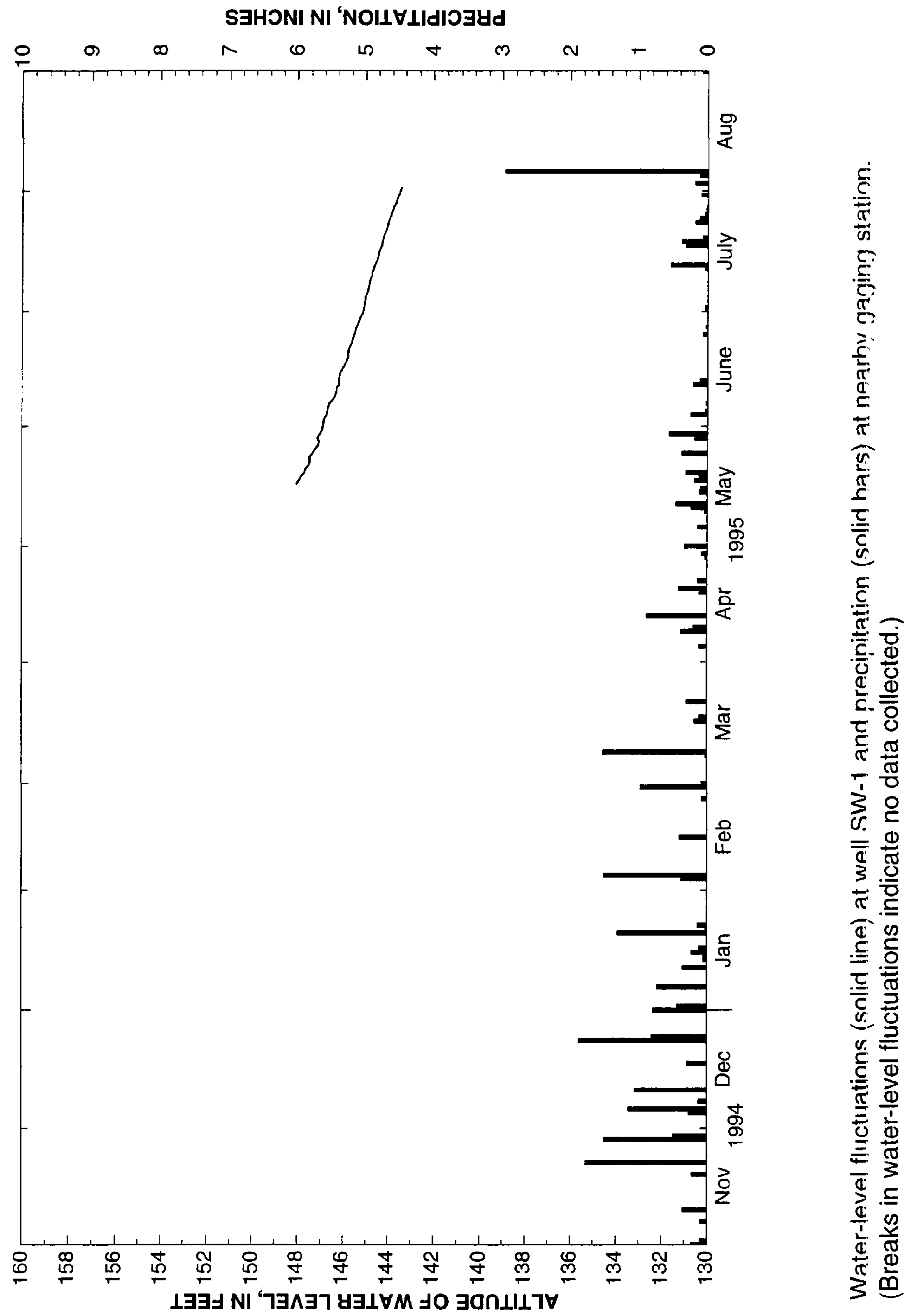




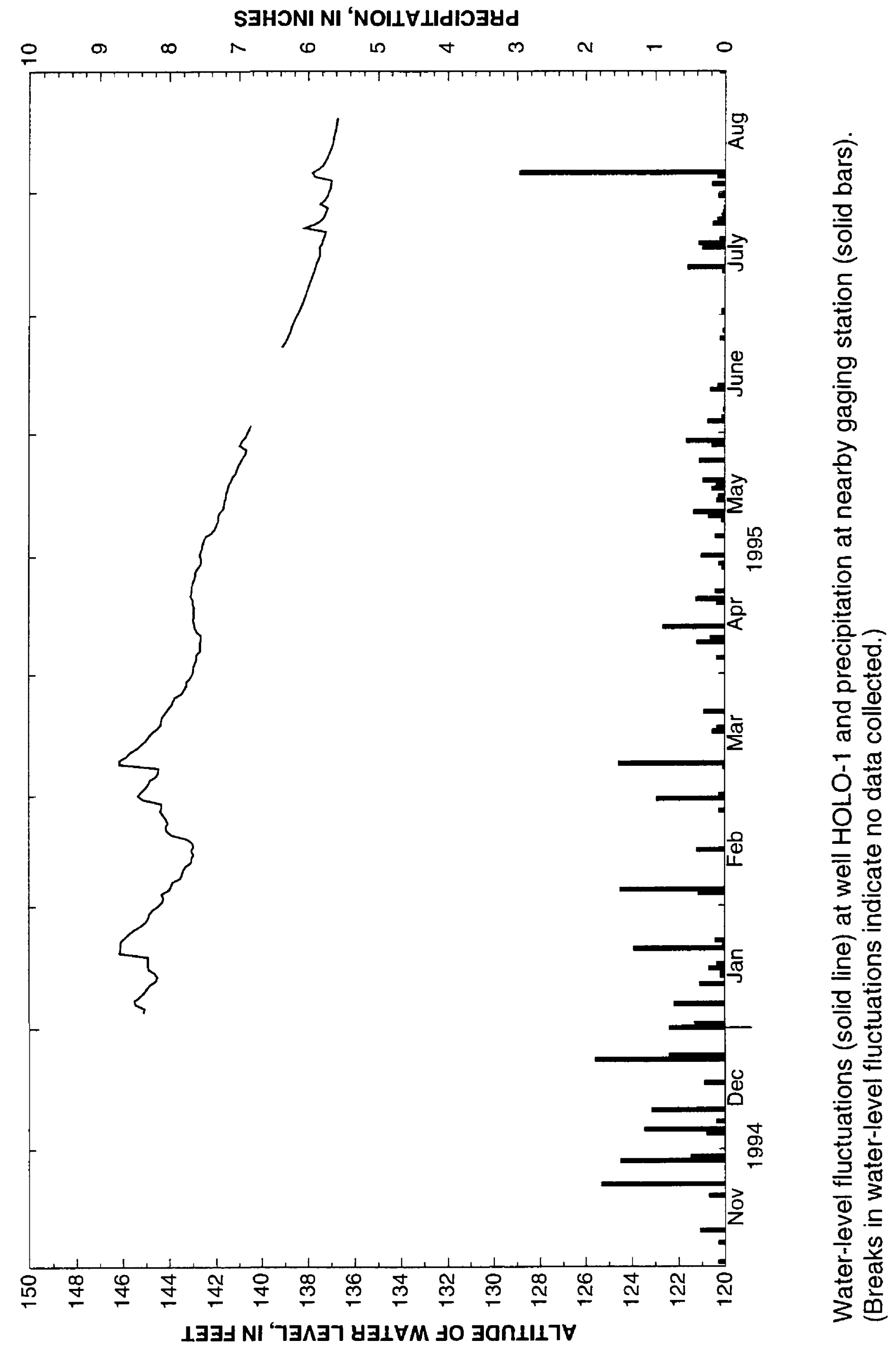




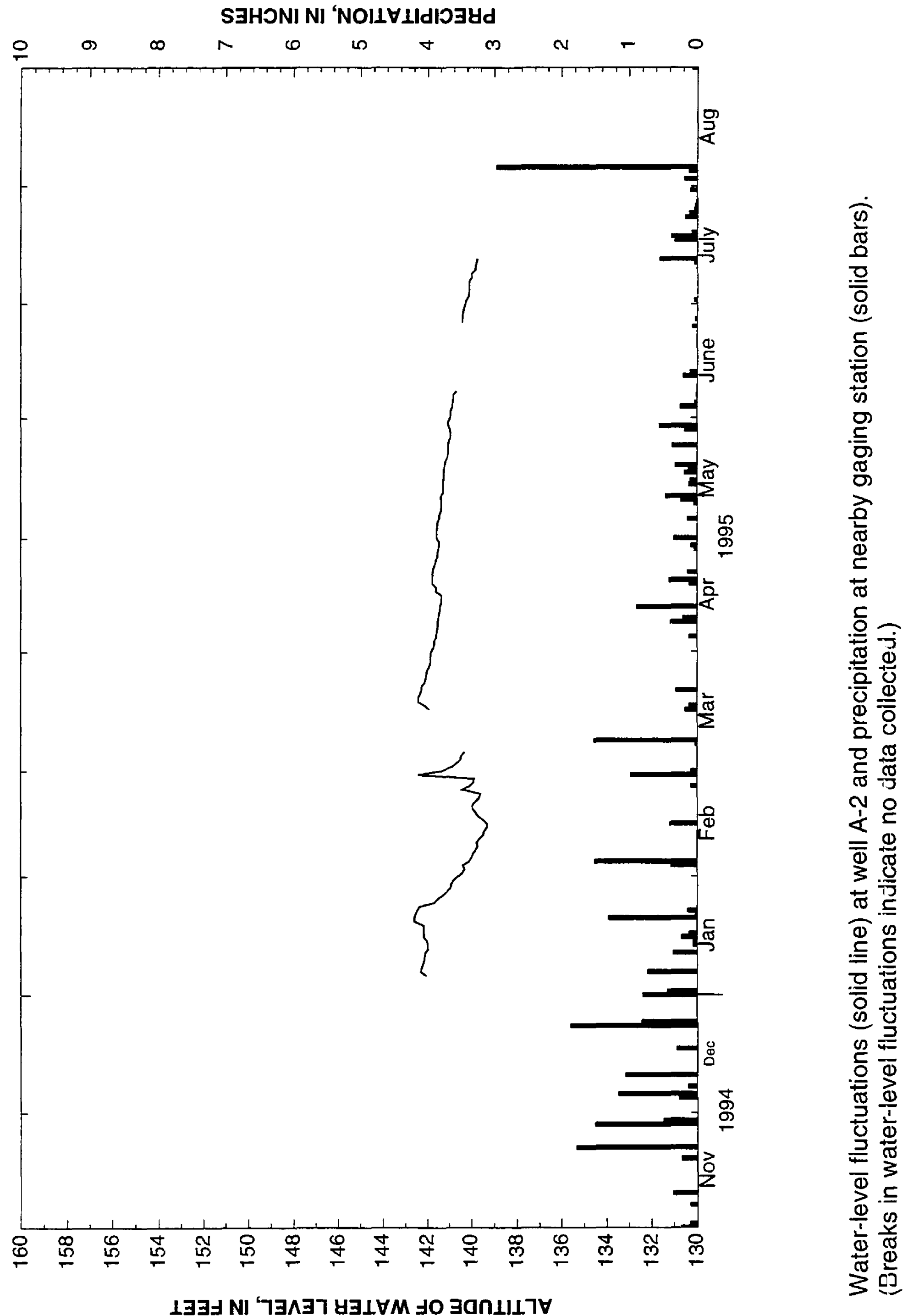




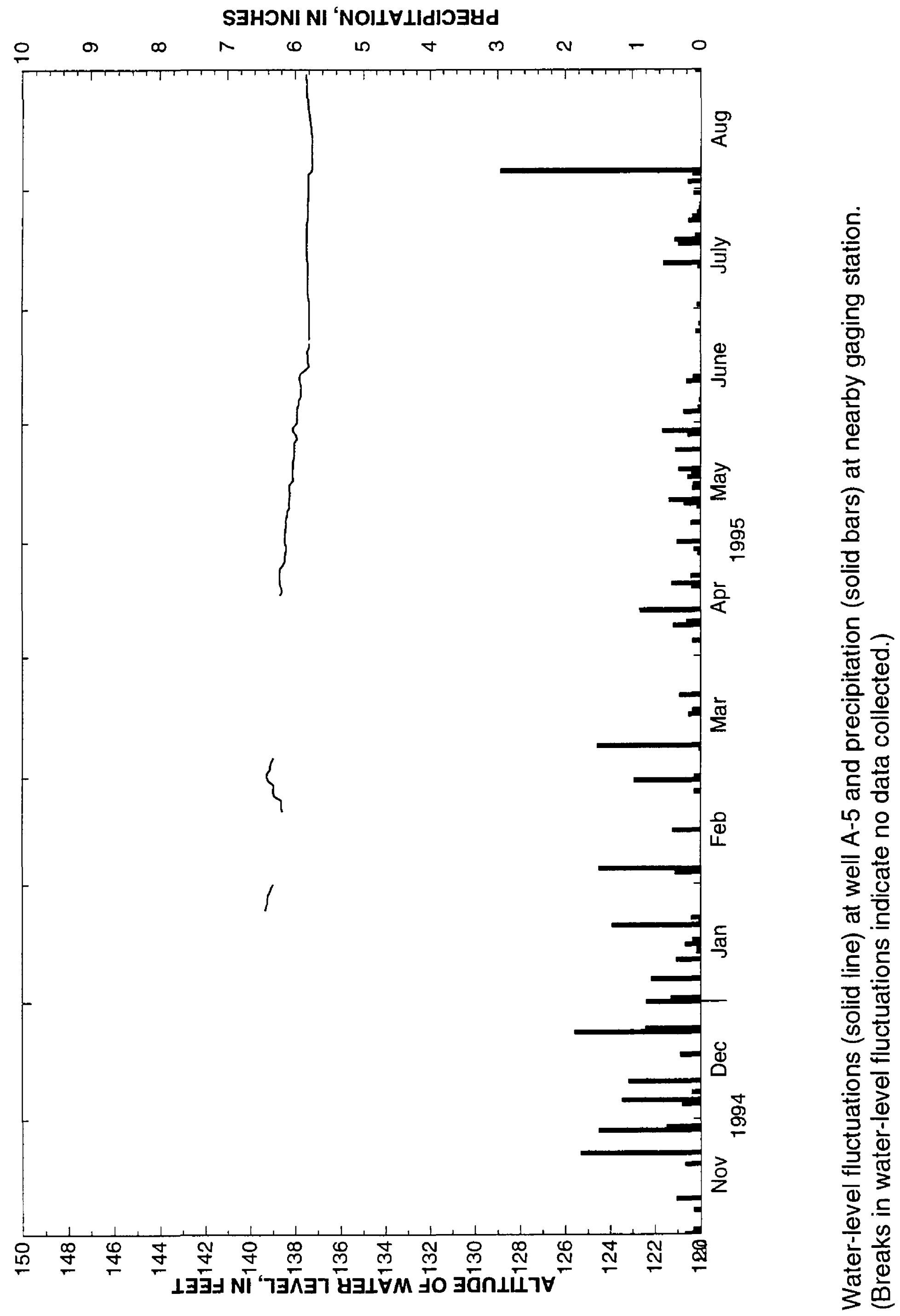




\section{SヨHONI NI 'NOIL $\forall I I d I O \exists Y d$}

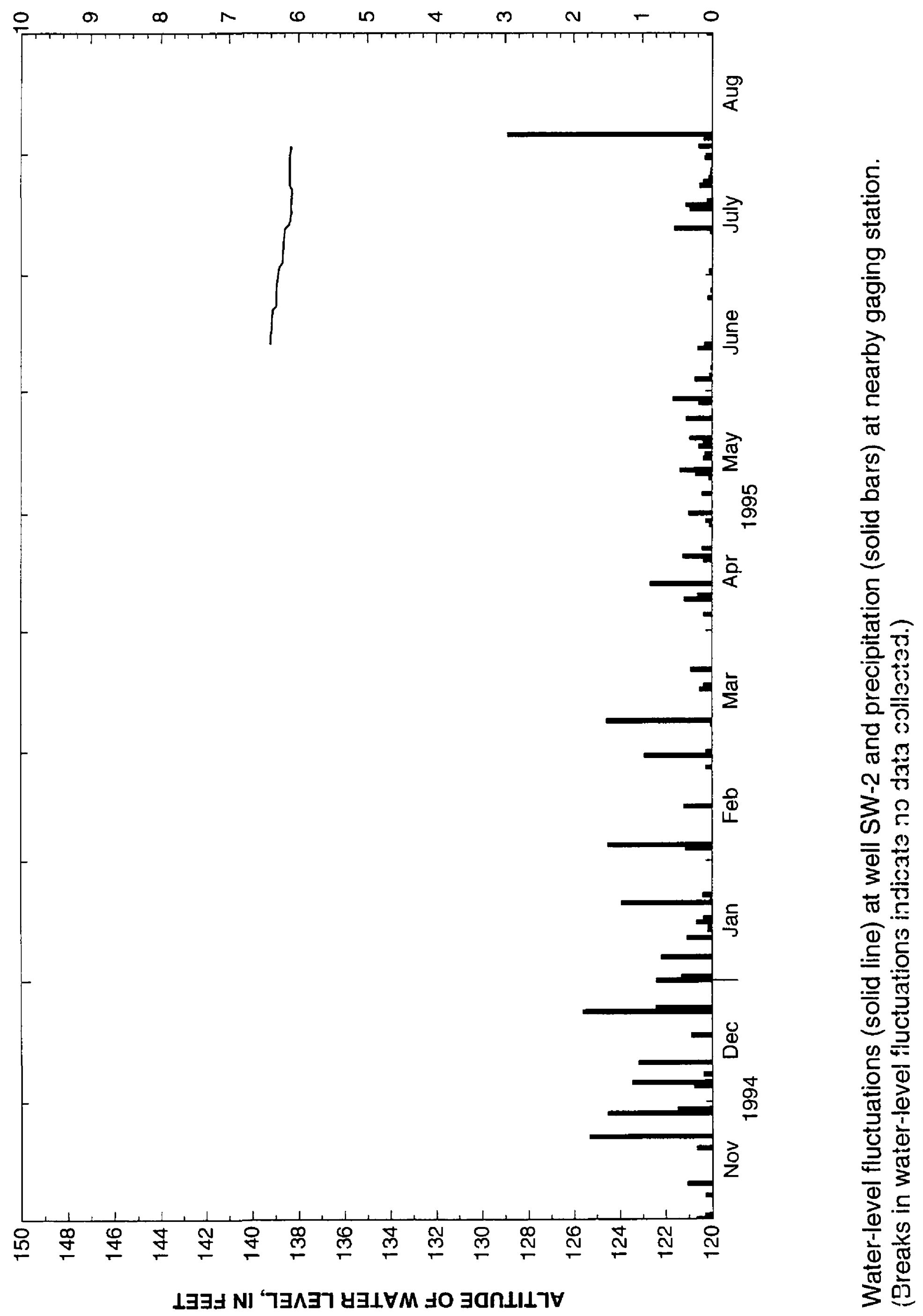


I NI 'NOLHLIdIOتYd

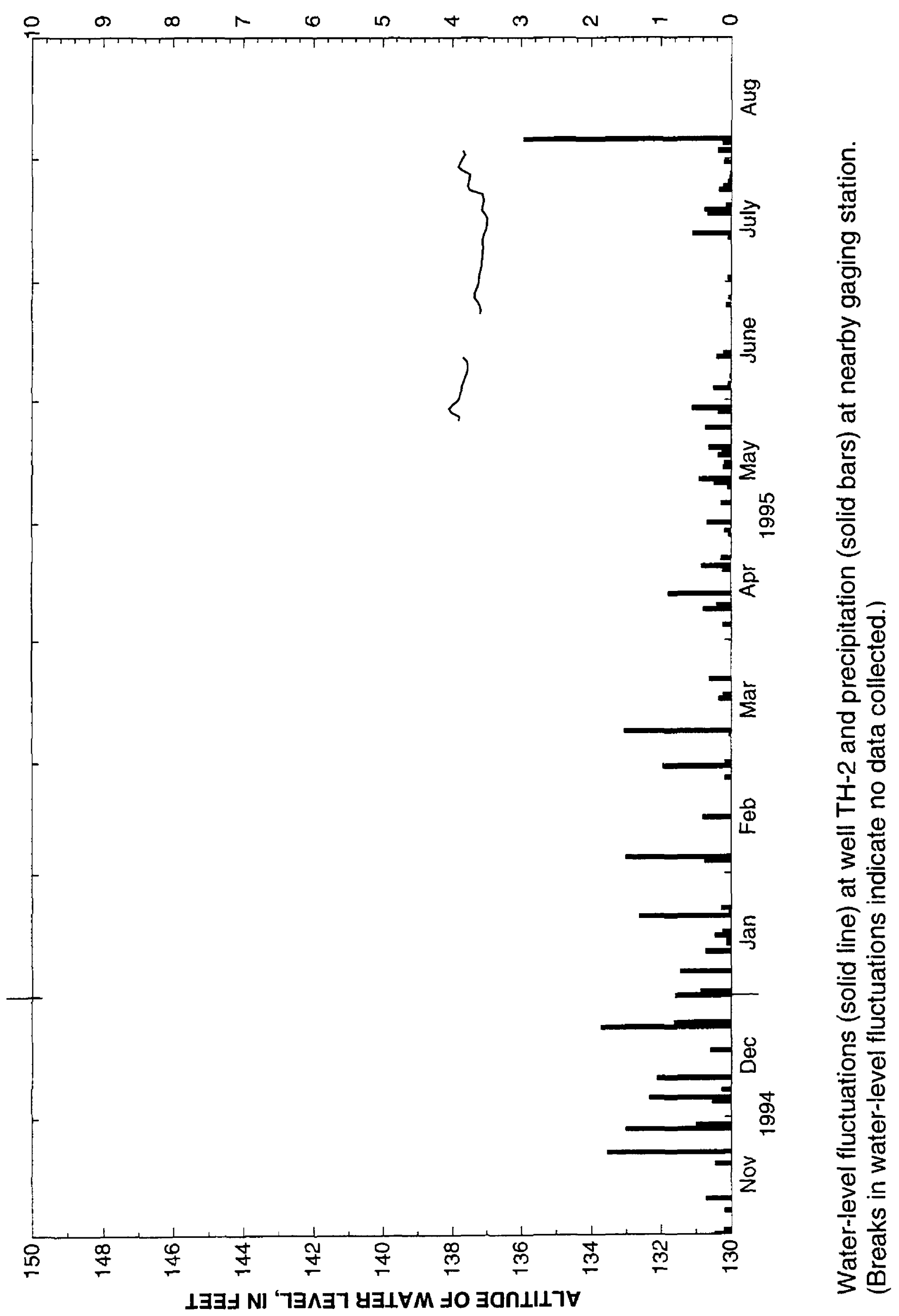




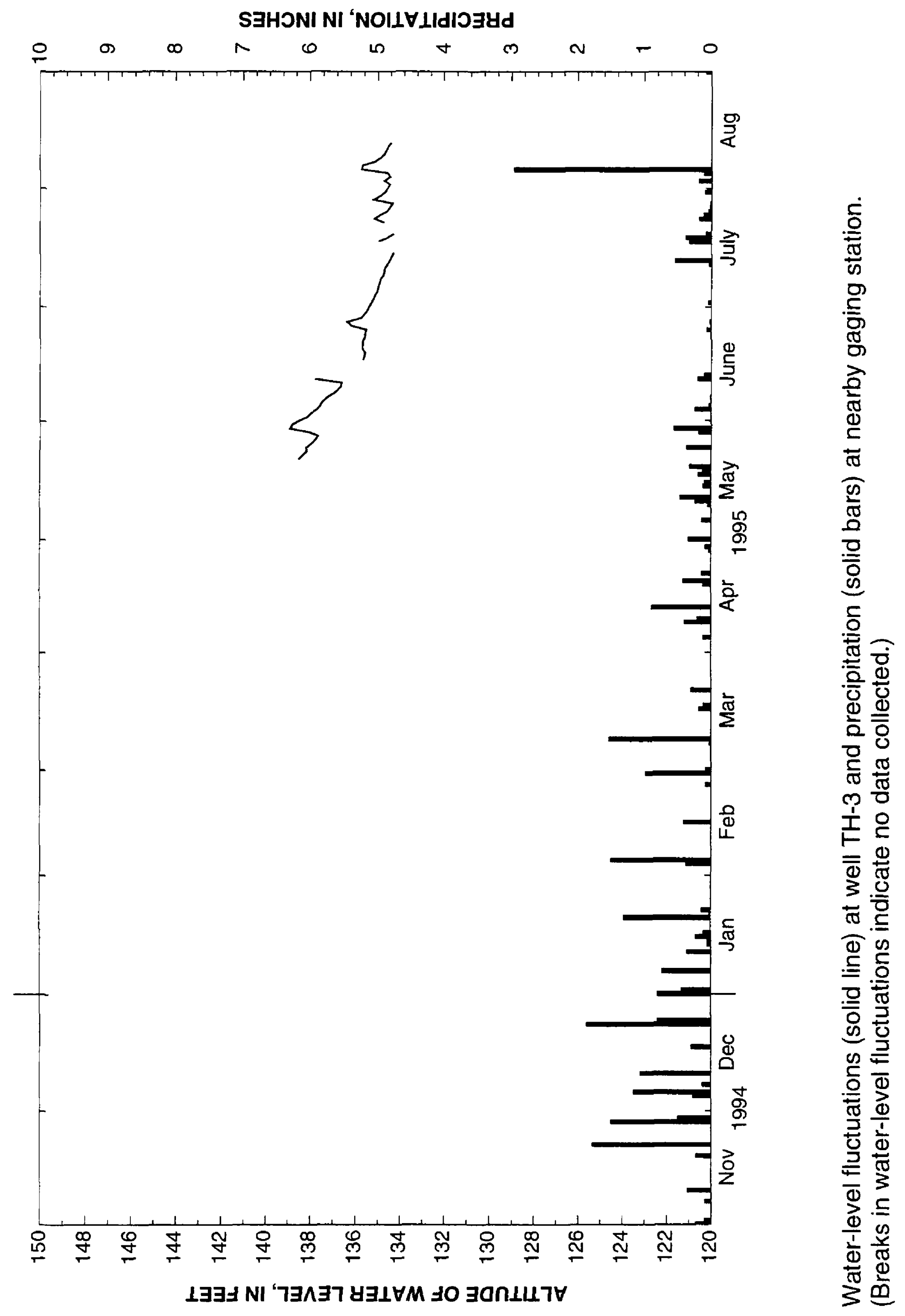


SتHONI NI 'NOILVLIdIOتYd

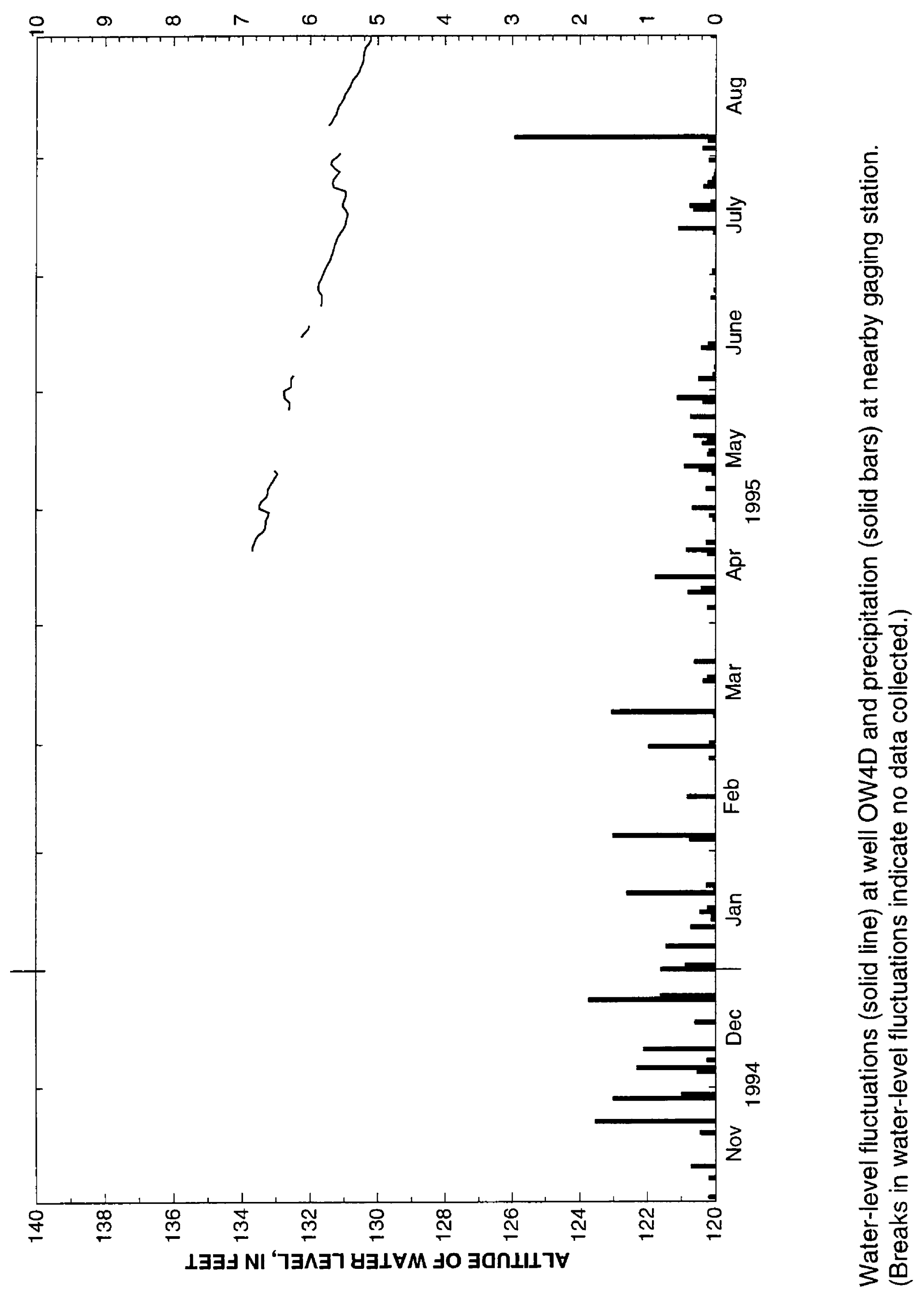


